
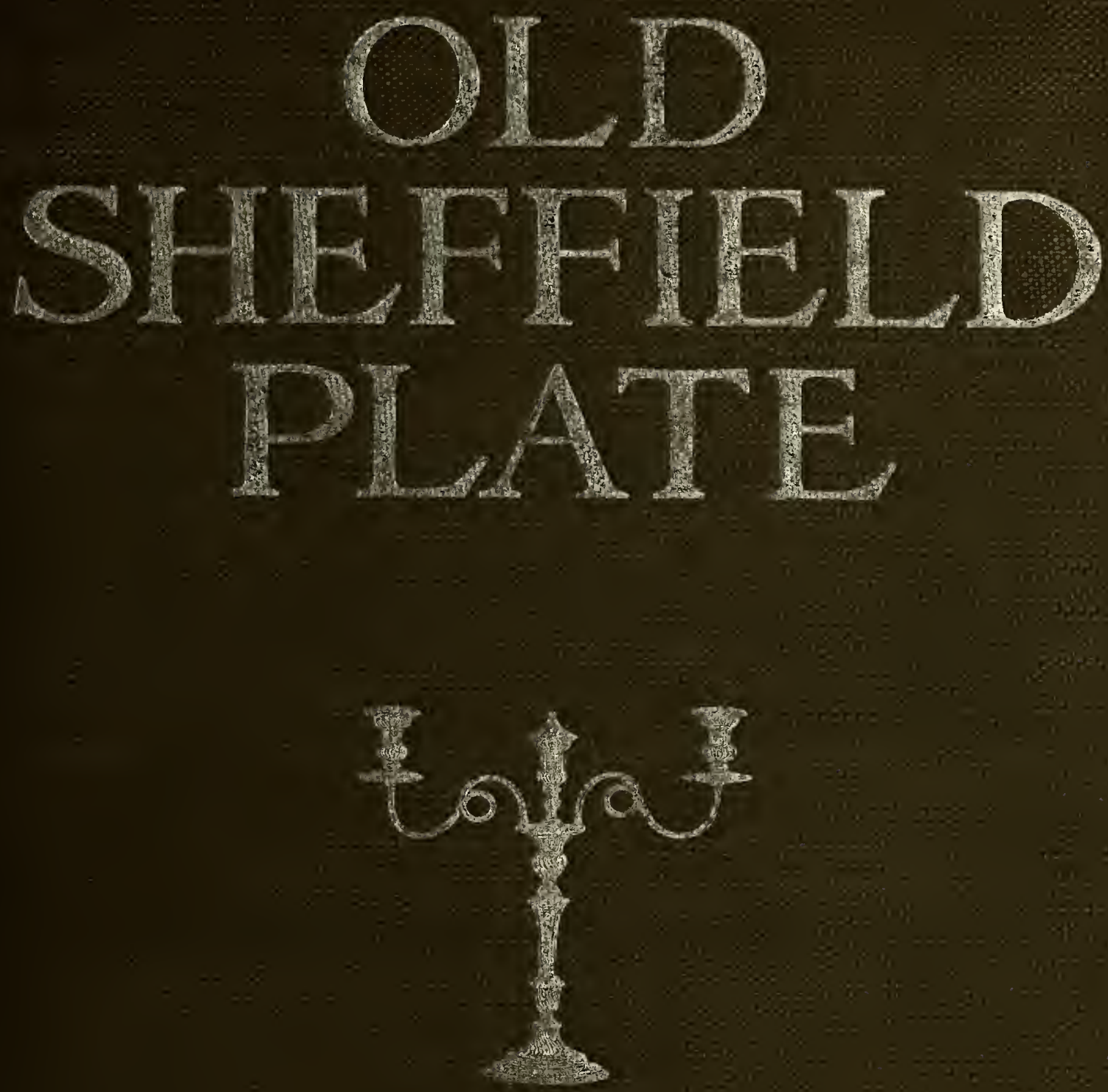

IULA WHITTEMORE TORREY 


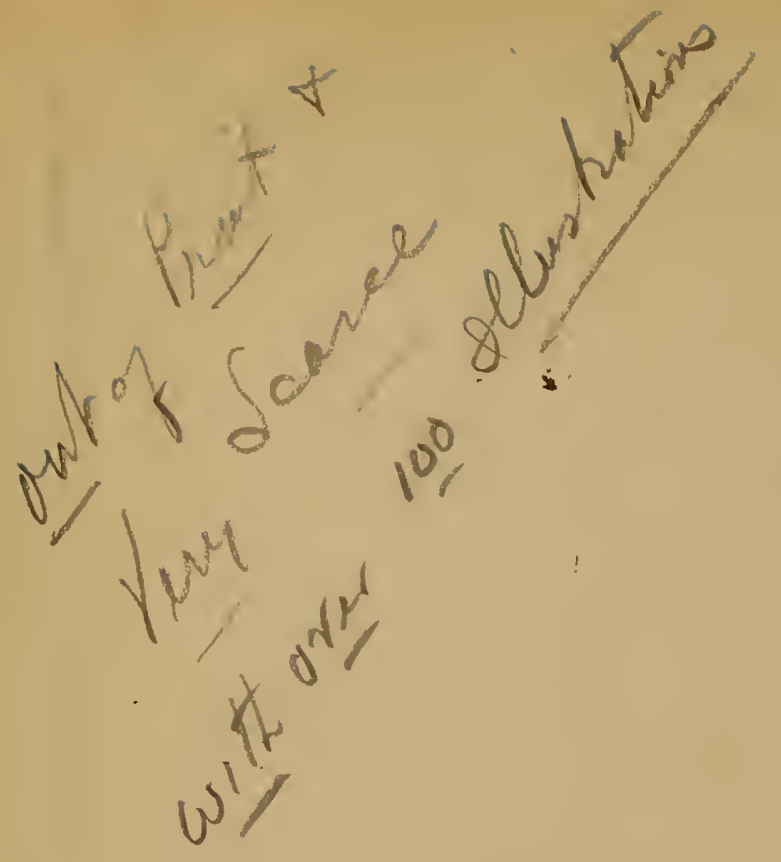





\section{OLD SHEFFIELD PLATE}

ITS TECHNIQUE AND HISTORY 

Plate I

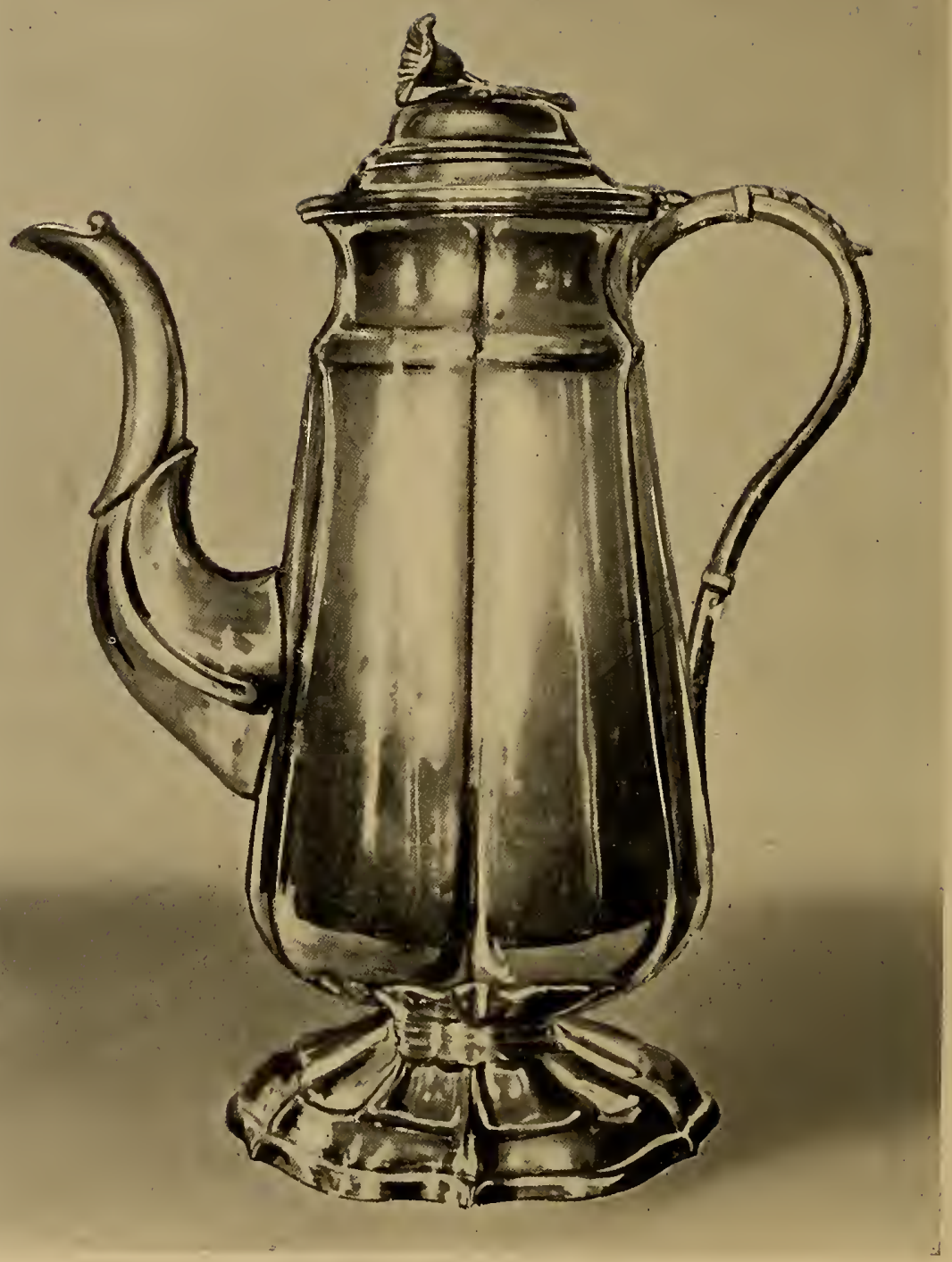

FLUTED CHOCOLATE-POT (I830) 


\section{OLD SHEFFIELD PLATE}

ITS TECHNIQUE AND HISTORY AS

ILLUSTRATED IN A SINGLE PRIVATE COLLECTION

BY

JULIA WHITTEMORE TORREY

WITH ILLUSTRATIONS

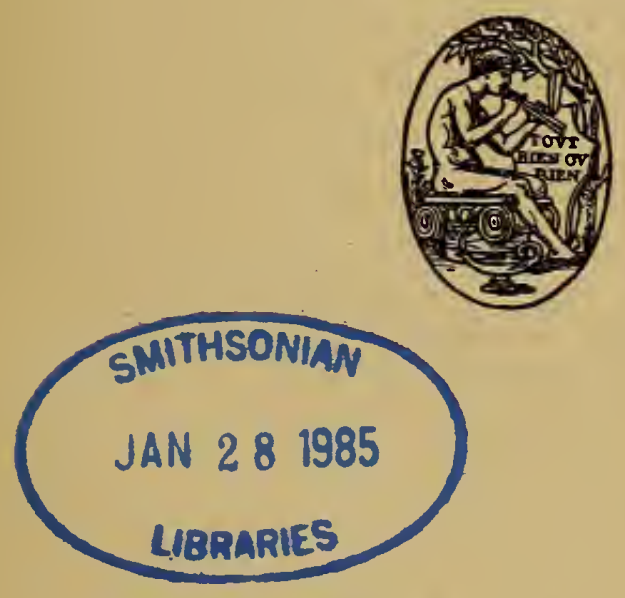

BOSTON AND NEW YORK HOUGHTON MIFFLIN COMPANY

The Eiberside press Cambritge

1918 
COPYRIGHT, IgIS, BY JULIA WHITTEMORE TORREY

ALL RIGHTS RESERVED

\section{Published September 1918}




\section{This Book is Dedicated}

\section{To $\mathfrak{A p}$ huband}

with whom the joys (and sometimes sorrows) of collecting have been shared and who takes a just pride in the collection, while disclaiming any responsibility for the book.

J. W. T. 



\section{PREFACE}

T THLE it claims no direct bearing upon the serious problems of existence in these strenuous times, this book is offered without apology; for concerning war directly and indirectly there is literature without end, and it has been virtuously assumed by many of us that the finer and quieter things of life must be too much neglected. The spirit of destruction is rampant, and is eating its way into our lives whether we will it or no. Our best energies are spent in the creation of huge and elaborate mechanisms for the sole purpose of destroying and of being destroyed. In view of this very fact is it not the more appropriate, in moments of necessary relaxation, to draw attention to some of the minor but truly excellent works of art that are well worth saving from the general wreckage? May not some fragments that have remained to us from the days when many an artisan was also an artist, help to revive in us the spirit of the workman who wrought well that his work might not only serve a useful purpose, but that it might also please and endure? While we are engrossed with weighty national problems it may be well to remember that there can be no one big solution of the great problem of all, that of keeping 
humanity human, but that our only hope lies in a thousand little solutions, mostly in the family and the home.

A delightful hobby is not a frivolous thing, and if this book shall convey a suggestion of the real pleasure that is bound to come from a close acquaintance with Sheffield Plate, it will have fulfilled its not altogether humble purpose.

Our collection is a record of personal experience, and every piece has a history and associations that are personal. It also illustrates certain principles, and I have tried to combine some application of these principles with some reminiscences that might be of interest or help to readers who possess some Sheffield Plate, or who know a little about it and would like to know more.

Collectors who wish to go into the matter more thoroughly may find the results of all the research work that has been done, or needs to be done, on the subject in "The History of Sheffield Plate," by Frederick Bradbury. Mr. Bradbury belongs to a firm whose connection for several centuries with this and allied industries has afforded him exceptional opportunities, and he has devoted years to the study of its history and technique. On these matters his book is the last word. I wish to acknowledge my indebtedness to Mr. Bradbury, both for personal courtesies in showing us through his factory and explaining many details of manufacture, and for much historical and technical material which I have frankly drawn from his book.

"Sheffield Plate" by Henry Newton Veitch is also an important contribution to Sheffield Plate literature.

For personal assistance I also wish to thank Mr. Walter Sissons of Sheffield, who showed us many interesting 
processes as now carried on in his works, and devoted considerable time to tracing the history of some of our pieces which were made by his firm; Mr. Francis Pairpoint of London; Mr. Samuel Barnett (Butt \& Co.), Chester; Mr. J. Corkill, Rock Ferry; and many other dealers throughout England who have helped us to find such specimens as we were looking for.

My thanks are also due to my publishers for the care with which they have reproduced my photographs.

\section{JULIA WHITTEMORE TORREY}

\section{San Diego, California}

December I I, I9I 7 



\section{CONTENTS}

I. The Original Thirteen . . . . . . . . I

II. OUr First Purchases . • . . . . . . . . . 6

III. The Small Articles that were made First . . . io

IV. Early Pieces of Hollow Ware . . . . . . I5

V. A Few Pierced and Chased Pieces . . . . . 21

VI. WIRE-Work • . . . . . . . . . . 25

VII. Silver Bands and Shields for Engraving . • . 3I

Vili. Candlesticks . . • • . . • . . . . 37

IX. A Visit to Sheffield . . . . . . . . . 43

X. Periods and Styles . . . . . . . . . 49

XI. Gilding and Close-Plating . . . . . . 54

XII. Some Curious Pieces for Special Purposes . • 57

XIII. Small Mounts and Other Accessories . . . . 63

XIV. Makers and their Marks . . . . . . . 65

XV. Reproductions and Fakes . . . . . . . 69

XVI. Where Old Sheffield Plate may be bought - and

Some Hints about Present Values . . . . 80

XVII. AN ObJect for StUdy . • . . . . . . . 89 



\section{INDEX TO ILLUSTRATIONS}

\begin{tabular}{|c|c|c|c|}
\hline \multirow{2}{*}{$\begin{array}{l}\text { ARGYLE } \\
\text { ASPARAGUS-TONGS }\end{array}$} & 82 & DISH-CROSS & 61 \\
\hline & I4 & DISH-RING & 61 \\
\hline & & Dish-STAND & 9 \\
\hline \multirow{2}{*}{\multicolumn{2}{|c|}{$\begin{array}{l}\text { BASKETS } \\
\text { See also Bread-baskets, Cake- } \\
\text { baskets, Sugar-basket, and } \\
\text { Sweet-baskets. }\end{array}$}} & $\begin{array}{l}\text { DISH-WARMER } \\
\text { See also Heaters. }\end{array}$ & 82 \\
\hline & & DisHes & 65 \\
\hline $\begin{array}{l}\text { SWeet-Daskets. } \\
\text { BEAKERS }\end{array}$ & 64 & See also Breakfast dish & es, En- \\
\hline BisCUIT-воx & 22 & & \\
\hline BOTTLE-STOPPERS & I0 & EGG-COOKERS & 57 \\
\hline BOUGIE-BOX & 43 & EGG-CUP STAND & 57 \\
\hline Box & 84 & EGG-CUPS & 57,76 \\
\hline BREAD-BASKETS & 72 & ENTRÉE-DISHES & 46,50 \\
\hline BREAKFAST DISHES & 80 & Epaulet & 84 \\
\hline BUCKLE & 56 & EPERGNES & 26,30 \\
\hline See also Shoe-buck & & EWER & 88 \\
\hline CADDY-SPOONS & 13,84 & FISH SLICES & 14,22 \\
\hline CAKE-BASKETS & $3,2 \mathrm{I}$ & FLAGON & 77 \\
\hline CANDELABRA & 42,43 & FLASK, HUNTING & 84 \\
\hline CANDLEsticks 38,40 & $\begin{array}{r}42,43,49 \\
76,80,84\end{array}$ & FORK-HANDLES & I0 \\
\hline Castors & 2 & GoBLEtS & 74,77 \\
\hline CHAFING-DISHES & 58 & GRAPE-SCISSORS & 56 \\
\hline CHEese-SCOOP & 56 & GRAVY-JUG & 82 \\
\hline Cheese-toaster & 60 & GRAVY-SPOON & I3 \\
\hline Chocolate-Pot & frontispiece & & \\
\hline Claret-JUGS & $20,34,44$ & HeATERS & 80 \\
\hline CoAsters & 49 & See also Dish-warmer & \\
\hline CofFEE-BIGGIN & 58 & HUNTING FLASK & 84 \\
\hline COFFEE-POTS & $8,52,78,82$ & & \\
\hline COFFEE SERVICE & 2 & INK-POT & 54 \\
\hline COFFEE-SPOONS & 12 & INKSTANDS & \\
\hline COMMUNION FLAGON & 77 & KNIFE-HANDLES & 10 $>$ \\
\hline $\begin{array}{l}\text { CREAM-JUGS } \\
\text { CREAM PAIS }\end{array}$ & 69,78 & KNIFE-RESTS & $2,10,56$ \\
\hline CREAM PAILS & 48,85 & & \\
\hline $\begin{array}{l}\text { CRUETS } \\
\text { CUPS, TWO-HANDLED }\end{array}$ & $\begin{array}{r}9,24 \\
18\end{array}$ & $\begin{array}{l}\text { LADLE } \\
\text { See also Soup-ladles } \\
\text { ladles, and Tumbler- }\end{array}$ & oddy -54 \\
\hline $\begin{array}{l}\text { DECANTER-STANDS } \\
\text { DisH-COVERS }\end{array}$ & $\begin{array}{r}49 \\
37.65\end{array}$ & $\begin{array}{l}\text { LEMON STRAINER } \\
\text { See also Strainer }\end{array}$ & 16 \\
\hline
\end{tabular}


LIQUOR-FRAME

LIVERY-BUTTONS

MARKS

MARROW-SCOOP

MEAT DISHES

See also Dishes.

MUFFINEERS

MustaRd-Pots

MUSTARD-SPOON

PIPE-LIGHTER

READING-GLASS

SALAD-CRUET

SALAD FORK

SALT-CELLARS

SALT-SPOONS

SALVERS

SAUCE-BOATS

SAUCE-TUREENS

SCALLOP SHELLS

SHOE-BUCKLES See also Buckle.

SNUFF-BOXES

SNUFFER-TRAYS

SNUFFERS

SOUP-LADLES See also Ladle.

SOUP-TUREENS See also Tureens.

SOY-FRAMES

Spoons.

See Coffee-spoons, Sugarspoon, Tablespoons, and Teaspoons. $\begin{array}{rr}9 & \text { StRainER } \\ \text { Io } & \text { See also Lemon strainer and }\end{array}$ Wine-strainer.

66-68 SUGAR-BASINS 29, 3I

56 SUGAR-Basket 22

65,70 SUGAR-BOX 86

SUGAR-CRUSHERS 12

76 SUgar PaILS 48,85

$74,76,78$ SUGAR-SPOON $\quad 56$

54 SUGar-TONGS I2, 84

SWEET-BASKETS 21,28

29 SWEET-DISH HOLDER 29

SWEET-DISHES $\quad 54,84$

64 TABLESPOONS IO, $\mathrm{I} 3$

TANKARDS I6, I8

9 TAPER-STICKS $\quad 38,43,54$

14 TEA-CADDIES $\quad 36,86$

$2,74,85$ TEAPOT-STANDS $\quad 32,36,74$

54, 84 TEAPOTS 6, $7,32,36,52$

2,50 TEASPOONS I2

8, 20, 69 TEA-TRAY 64

60
77 Tee also Trays.

IO TOAST-RACKS 9, 28

TODDY-LADLES I4

84 TOOTH-PICK HOLDER 84

$37,43,70$ Trays 34,74

43, 56 See also Tea-tray.
14 Tumbler-LADLE

TUMBLERS 54

32, 44 TuReEns 32, 44, 65

62,80 See also Sauce-tureens.

WAX-WINDER 43

WINE-COOLERS 63

WINE LABELS IO

WINE-STRAINER 74 


\section{OLD SHEFFIELD PLATE}





\section{OLD SHEFFIELD PLATE}

I

\section{THE ORIGINAL THIRTEEN}

$7 \mathrm{HE}$ collection which forms the subject of this and the

1 following chapters has a simple though somewhat unusual history. It resulted from a more or less accidental interest in a discontinued industry, occasioned by the possession of a few exceptionally fine specimens that had come down from the days when our American forefathers were rejoicing in the prosperity of a vigorous young republic.

These we had carefully cherished, but as the only other articles of the kind that were familiar to us were possessed by our friends, and we were not at the time familiar with auction rooms, nor had any more than a passing interest in the treasures that lie buried in antique shops, the possibility of adding to their number had never occurred to us. Like many other Americans, we had the feeling that, aside from family heirlooms or things with special associations, new household possessions, like garments, were better than old.

Upon our removal to England, however, our New England sentiments underwent a change. With a baker's dozen of Sheffield Plate heirlooms for a nucleus, and new facilities for acquiring other specimens together with an extended 
knowledge of their alluring qualities, my husband and I naturally yielded to the fascination of such beautiful objects, and almost before we realized it found ourselves the owners of a very passable collection. The slower process of filling in with rarer pieces, accompanied by the weeding-out of indifferent ones, has formed a stimulating pastime during a dozen years' residence in the country where this wonderful industry originated.

Most of the older American families are still in possession of some pieces of antique silver or plated ware that have come down from previous generations. The silver has always been duly esteemed and honored, but until recently much of the plate, perhaps shabby with age but of tener only dingy with neglect, has lain unappreciated or quite forgotten on the upper shelves of some seldom visited cupboard, while the owners have contentedly accustomed themselves to more or less abominable productions made by modern machinery. Nowadays, however, the craze for antiques of every description has revived the interest in the old plated ware; and since this cannot be carefully studied without developing some appreciation of its beauty, one may see in many a New England home an odd pair of candlesticks, or a cake-basket in genuine Sheffield Plate, that has finally been restored to a place of honor.

At the time when these things were brought to the United States, most American industries were in their infancy. Comparatively little silver, and so far as is known, no plated ware was manufactured at home. Such silverware as was made, however, was of the very best. It was wrought by skilled artisans, like Paul Revere, who designed every piece and executed it with his own hands. While the quality of Ameri- 
Plate II

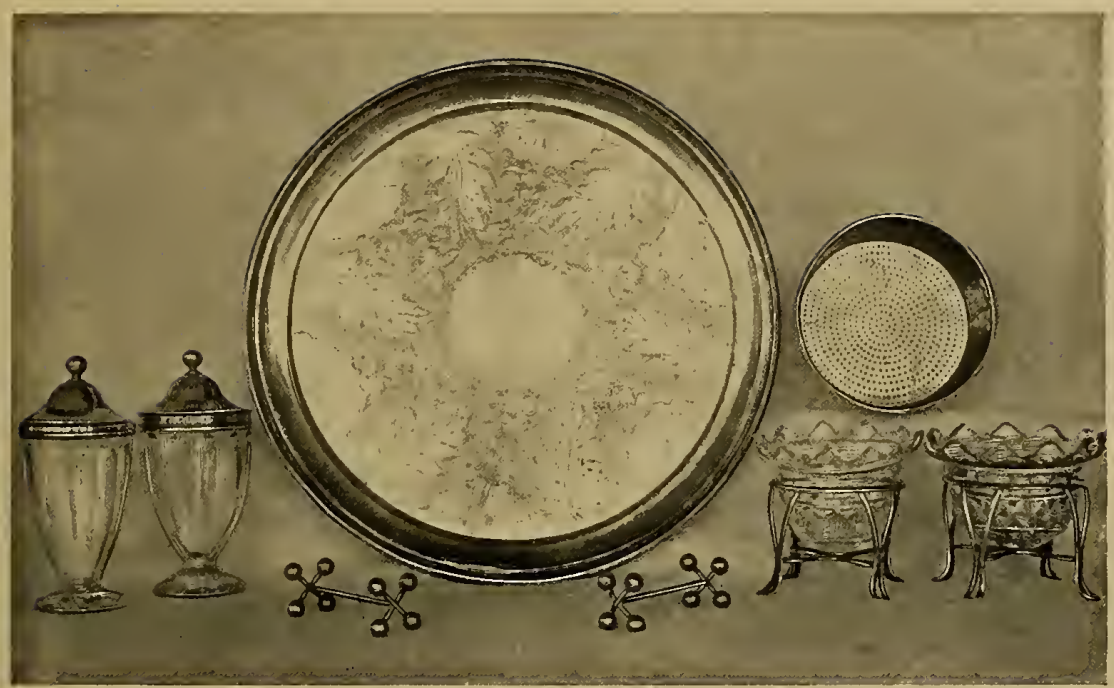

CUT-GLASS CASTORS WITH SHEFFIELD PLATE TOPS (I800)

CHASED SALVER WITH SWAGED BORDER (I8r5)

PLAIN STRAINER WITH SILVER THREAD EDGE (I795)

PAIR OF WIRE-WORK SALT-CELLARS WITH CUT-GLASS BOWLS (I804) PAIR OF KNIFE-RESTS (I800)

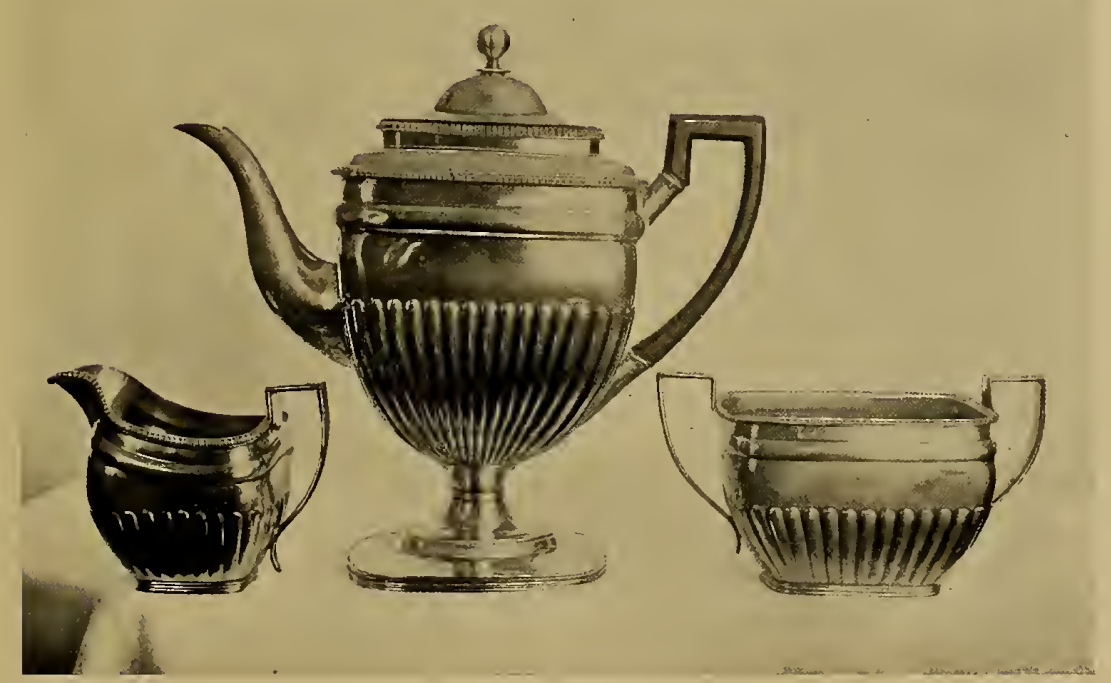

COFFEE SERVICE (I४IO) 

Plate III

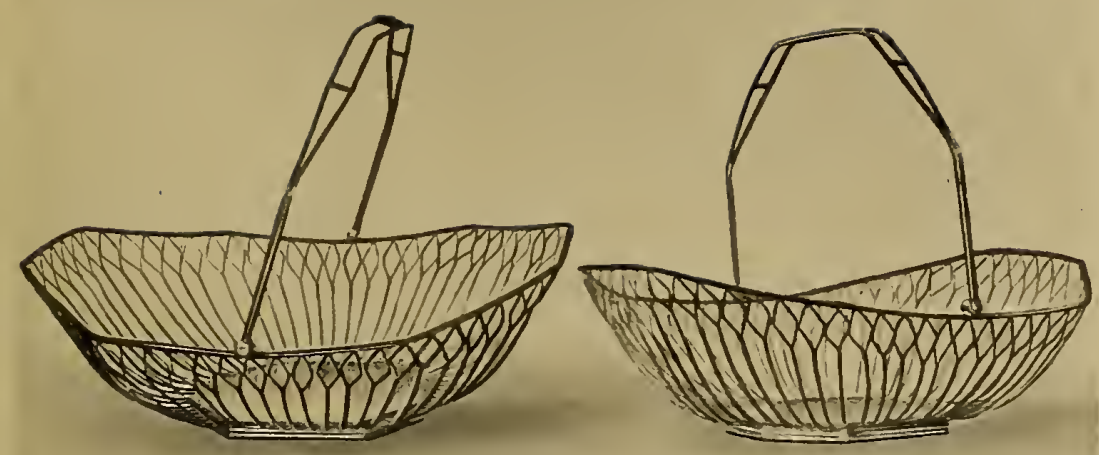

PAIR OF IVIRE-IVORK CAKE-BASKETS (I79O)

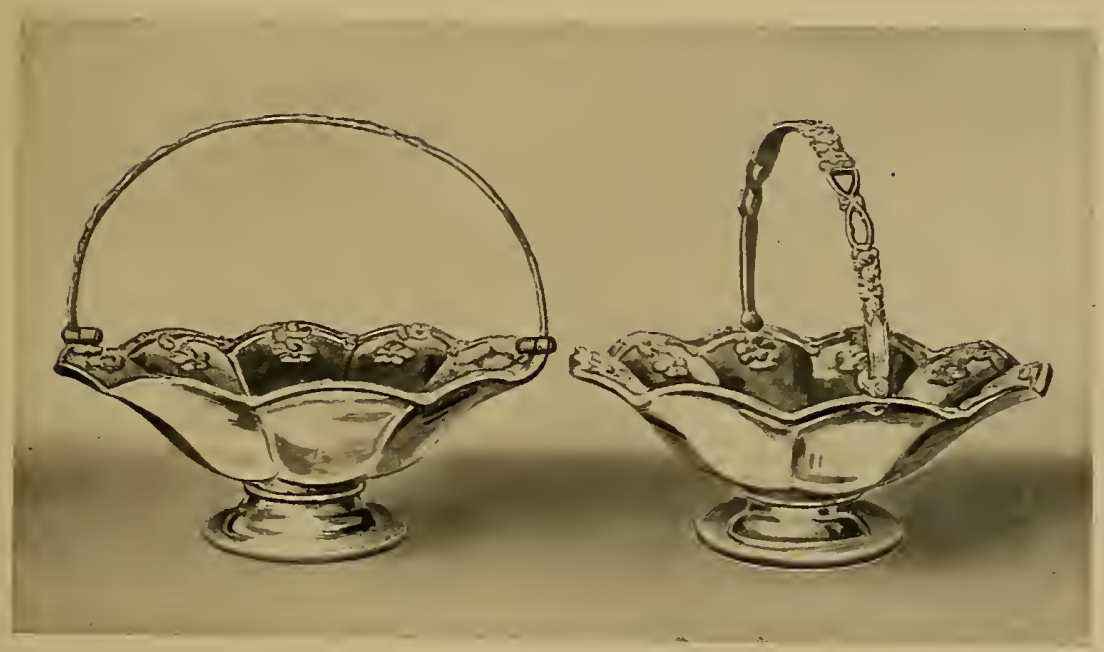

PAIR OF CAKE-BASKETS (I835) 

can home products in those days was unquestioned, the supply was naturally far behind the demand, and the houses of the wealthier class, especially in the seaboard towns of New England, were furnished very largely from the English workshops. This fortunately was at a time when workmanship was at its best, and before public taste had begun to deteriorate, as it did in "Early Victorian" days. With the Heppelwhite and Sheraton furniture came the Sheffield Plate that will always belong with it.

When we transferred ourselves and our household goods from New England to Old England, our knowledge of our "old things" was somewhat meagre. We knew that our Sheffield Plate was beautiful in design and exquisitely made; its copper foundation was obvious in places; but we were not without some qualms as to how it would compare with what we should find in the old country. Now, however, after years of studying and collecting, we find that these pieces still hold their own conspicuously among the best, and testify to the good taste which has prevailed in American homes from the first. It is largely due to the excellent quality of these original pieces that we owe our rapid acquisition of knowledge during the first years of collecting. Often enough we should have felt hopelessly at sea before a bewildering assemblage of wares that looked attractive and were falsely guaranteed genuine, without these undoubtedly right pieces for comparison.

One often sees clumsily made but not always ill-shaped specimens of wire-work which cannot fail to look crude to one who has lived with the cake-baskets shown in the preceding illustration. We have been fortunate enough to find others equally fascinating in their way, but in all our travels we 
have never discovered anything that better represents the wonderful skill of the early workers in plated ware.

While doubtless there are plenty in existence, it happens that we have never seen cake-baskets in pairs outside our own collection. They must have been a popular article in old New England days, for we ourselves originally had three pairs of them, and they are among the articles of old Sheffield Plate most frequently seen to-day on American sideboards.

The second pair represent a much later style than the wire-work ones both as to design and method of construction. Owing to the latter, they show greater effects of wear, the floral mounts of their silver being worn through in places where the raised surfaces have had most rubbing, thus exposing bits of the leaden filling. Fortunately these signs of age increase very slowly, and though the baskets are in daily use (for fruit, for which they seem more suitable than for cake), they show no perceptible change from year to year.

The third pair of baskets met with a melancholy fate, for they belonged to the class of Sheffield Plate that cannot be satisfactorily renovated, and when once worn out is only fit for the scrap-heap. They were round solid baskets, similar to the above, but while the latter are plain on the inside, the others were elaborately chased. They were probably made from less heavily plated metal, or had received less kindly treatment, for the copper was not only much in evidence but deeply corroded. After unavailing efforts to make them presentable by constant cleaning, we were obliged to discard them as unfit for use and of no further interest, as there was nothing exceptional in the design to make them worthy of a place in a collection. 
Perhaps the most interesting group in the portion of our collection that re-crossed the Atlantic is the coffee service, Plate II, which in its completeness is exceptional. Good coffee-pots are not infrequent, odd cream-jugs and sugarbasins are seen occasionally, but somehow the old sets seem to have been nearly always divided, or a portion of them worn out. Until a more careful study revealed the reason, we often wondered why these three pieces appeared so little used. The secret lies in the method of construction and wonderfully skilful workmanship.

Here every part that is subjected to harder wear is strengthened by an additional thickness of silver, and the whole is put together with a neatness and precision that make it difficult to detect after all these years that we are dealing with plated ware and not solid silver.

This design, with its graceful flutes and gadroon edges, is frequently referred to as "Queen Anne," but it is not an exact copy of the oblong shapes used in the days of that popular monarch. Those were rather clumsy and ungraceful, though of ten attractive on account of their strong individuality. The coffee service belongs to a period (about I8Io) when more generous dimensions were in vogue, but before the beauty of line and proportion had been sacrificed to ostentatious bigness and florid decoration, as was unfortunately the case at a later period, with the productions of which we have happily very little concern. 


\section{OUR FIRST PURCHASES}

T $\mathrm{N}$ the land par excellence of tea-drinkers, a Sheffield teapot 1 to supplement the coffee service was a necessity, and not many weeks after our arrival in Liverpool, my husband proposed that we go and buy one. Not realizing how difficult it would be to find surviving specimens of an article that has had the hardest and most constant use for generations, we started out for a jeweller's shop, where a placard in the window announced that old silver could there be bought or sold. We were followed by true beginners' luck, and we were not surprised to find exactly what we had come for, a very satisfactory teapot at a moderate price. It was carried home in triumph and used daily for a year or so till we became more knowing and discovered that it had been replated. Afterwards finding another in original condition at the same shop, we negotiated an exchange. The second teapot in time made way for others of better design, and in the end was given to a friend who really fancied it.

The first teapot to find a permanent place in the collection is the octagonal one illustrated. It is larger than the average, and in excellent condition. The design speaks for itself. 
Plate IV

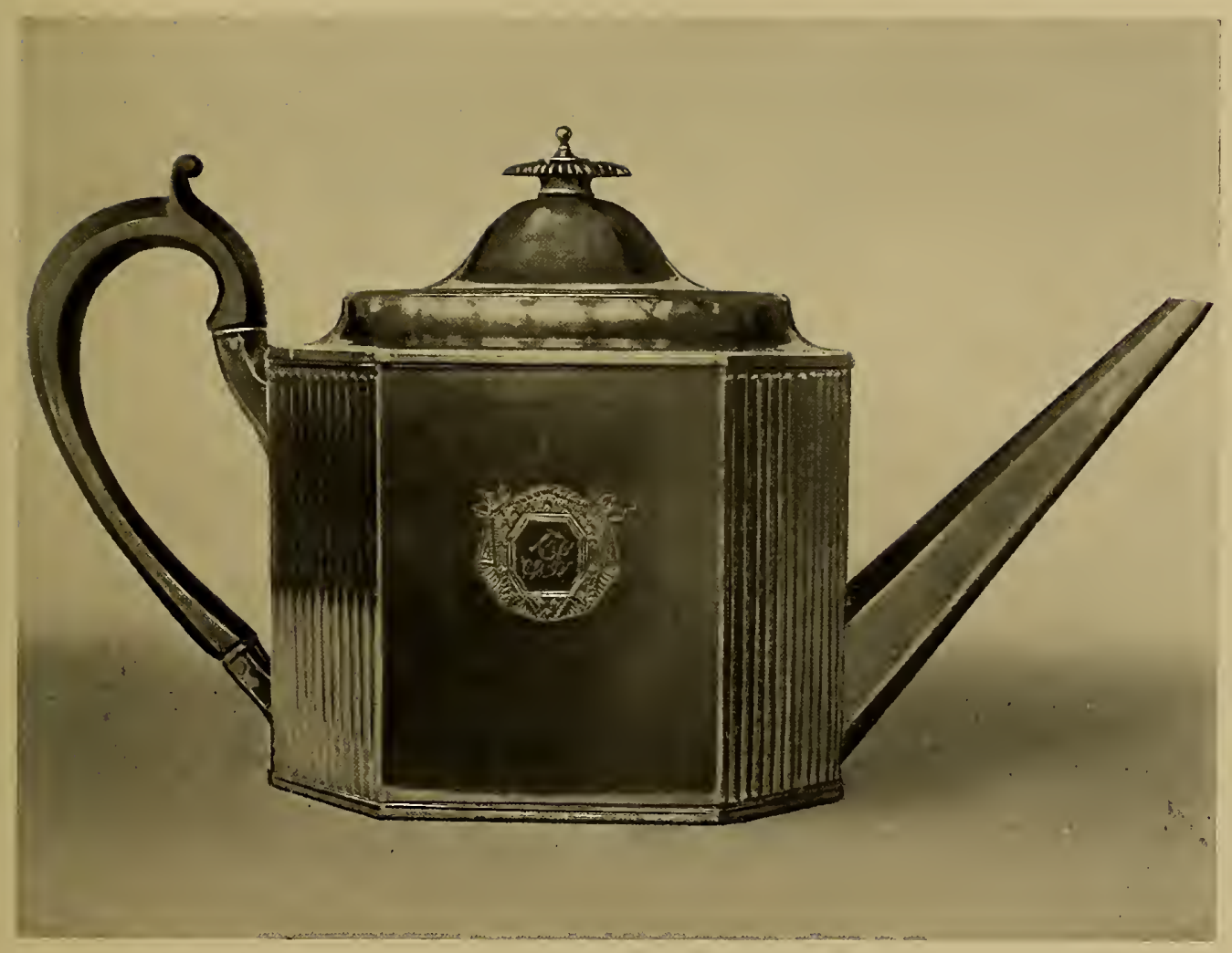

QUART TEAPOT WITH FINELY CHASED THREAD EDGES OF ROLLED PLATE (I780) 

Plate V

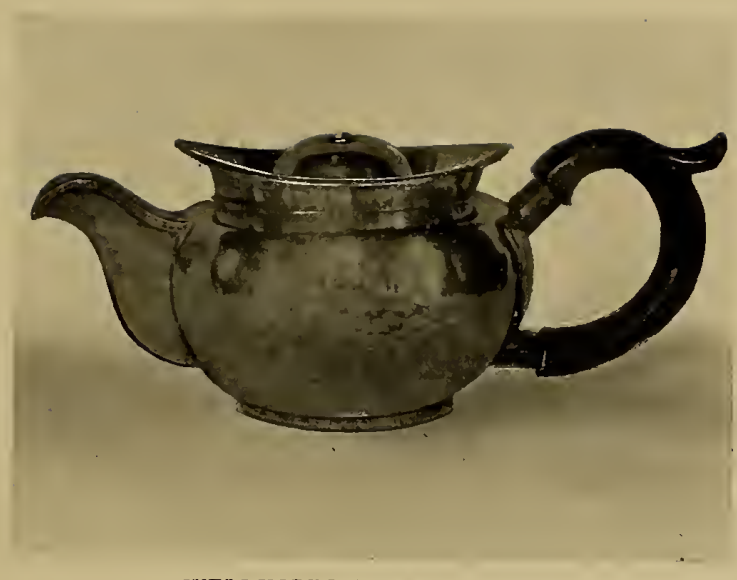

WVLLINGTON TEAPOT (I820)

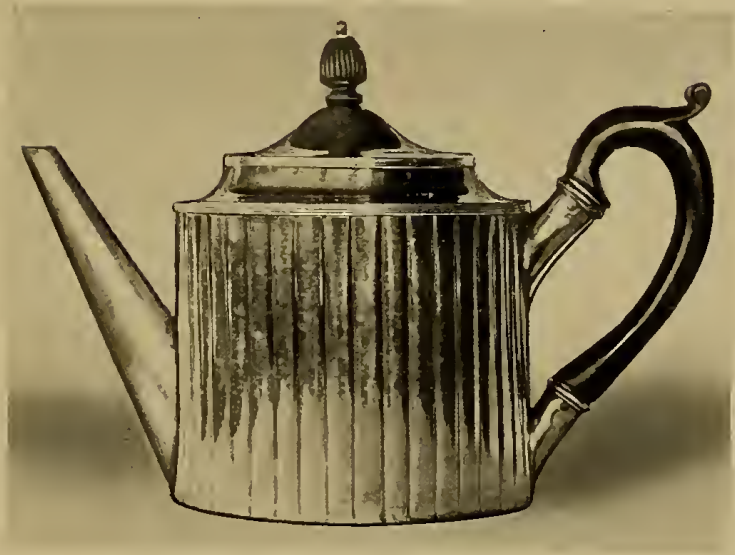

UVAL FLUTED TEAPOT (I790) 

In a small Lancashire village, we know a funny old house with what was once a garden in front of it. The house is now used for the storing of second-hand furniture, and open-air auction sales are held weekly in the old garden. It would be difficult to imagine a more dismal assemblage of worthless rubbish than is usually displayed here on a Thursday afternoon, but it occasionally happens that articles of considerable interest still find their way into just such untoward surroundings.

On passing this curious establishment one day while the sale was proceeding, I discovered a basketful of miscellaneous articles which I bid off for three shillings and sixpence. Among other articles were two flat-irons, a china toast-rack, an imitation Wedgwood jug, some articles of tinware, wooden clothes-pegs, and the round Sheffield teapot with the flaring rim. Every portion of the poor thing was as black as the ebonized handle, and only the design at first sight distinguished it from a neglected bit of old tinware. The other bidders showed some surprise when I returned the remainder of my purchase to the auctioneer, and departed with the little teapot, which one of the bystanders remarked was all handle and spout. The black on the surface had been the slow accumulation of years; but after much hard rubbing, the heavily silvered body emerged in very passable condition.

We afterwards learned that this style of teapot is known as the "Wellington." It is similar to one which the Iron Duke always carried with him, and the shape became exceedingly popular after Waterloo.

The little fluted teapot is charmingly simple. We found it by accident, while exploring in a small town where we had to wait for a train. 
During the early days of our collecting, we made the acquaintance of a curio-dealer who had been one of the pioneers in the buying and selling of antiques nearly half a century ago. A cabinet-maker by trade, he had been among the first to recognize the beauty of the older furniture, while his wealthy customers were destroying good Chippendale to make way for the heavy monstrosities which had become fashionable. He told us how he had seen beautifully carved chair backs used for firewood, and cart-loads of halfworn Sheffield Plate sold as junk.

As the taste for the older and better designed furnishings began to revive, this dealer was among the first to take advantage of the turn of affairs, and bought cheaply many fine specimens that he rightly foresaw would be in demand later. These had accumulated (with more purchases than sales) until, when we first knew him, his shop was literally packed with all sorts of goods that had known very little sorting, and the old man admitted that he himself did not know what was below the surface.

One day our friend announced his intention of opening some old chests that had been locked for over thirty years, and he was not allowed to escape until they had been dragged out and every drawer emptied. 'The contents were comparatively small articles, mostly china, all carefully wrapped in newspaper. We inspected every item with interest, but what we were really waiting for appeared only at the very last. It was a single package containing the highly prized "pear-shaped" coffee-pot and the accompanying sauce-boat. Both were quite black, but found to be in beautiful condition when cleaned. Like many other pieces which look exactly similar, they show differences in construction 
Plate VI

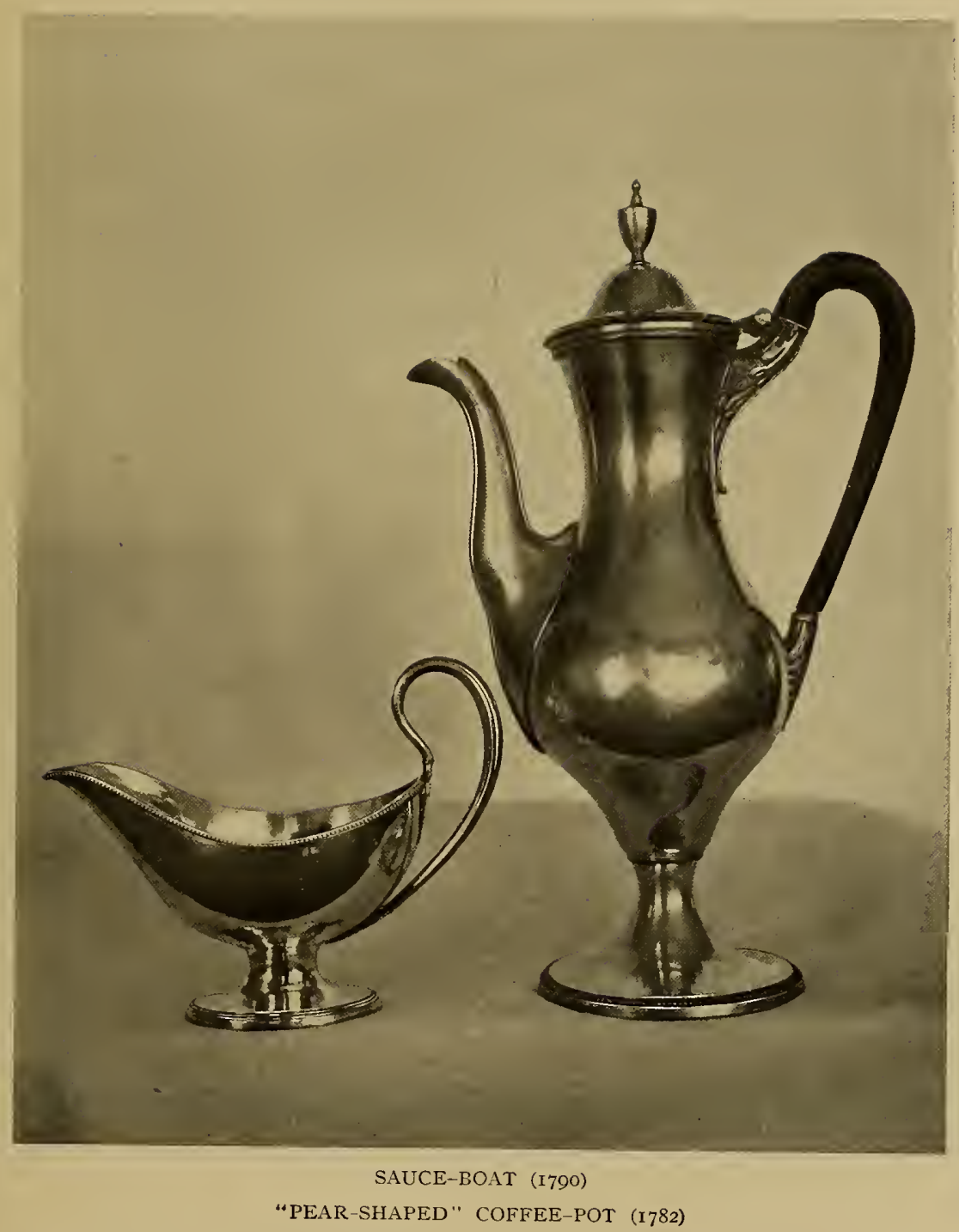





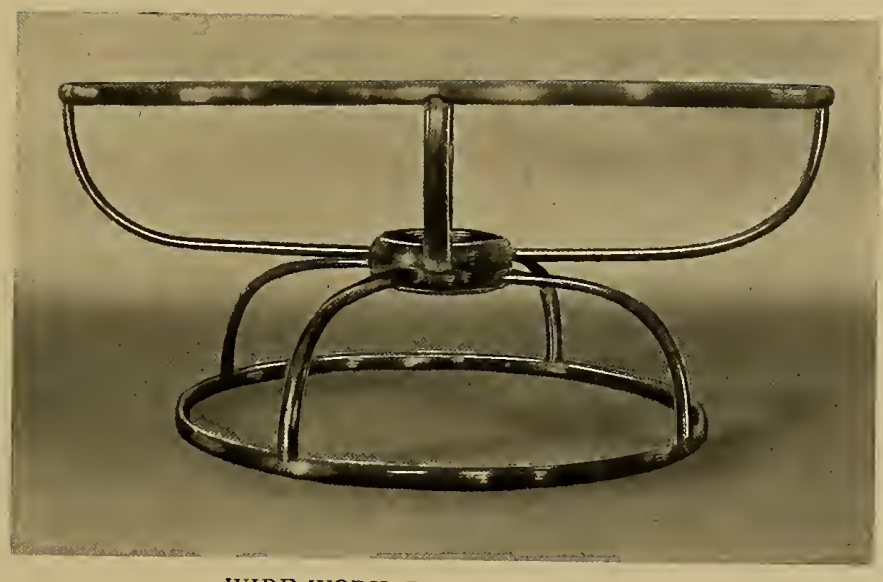

WIRE-WORK DISH-STAND (I790)

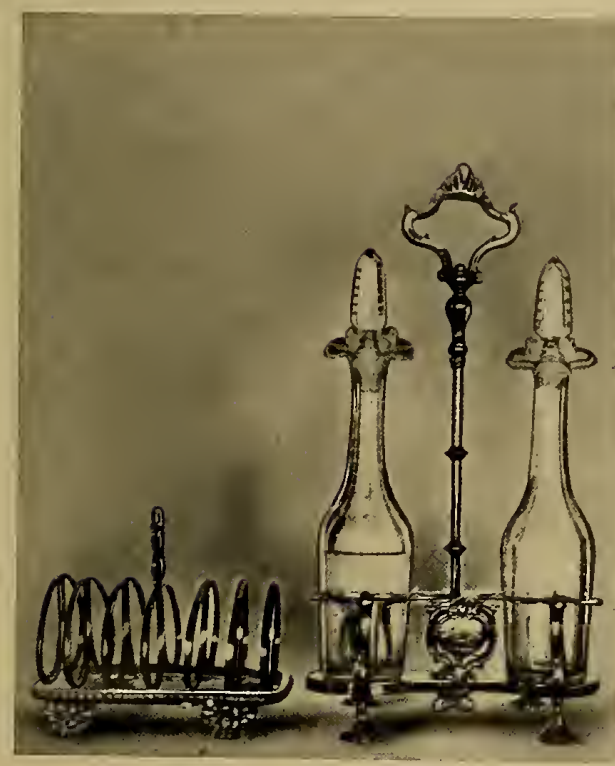

TOAST-RACK (I8IO) SALAD-CRUET (I820)

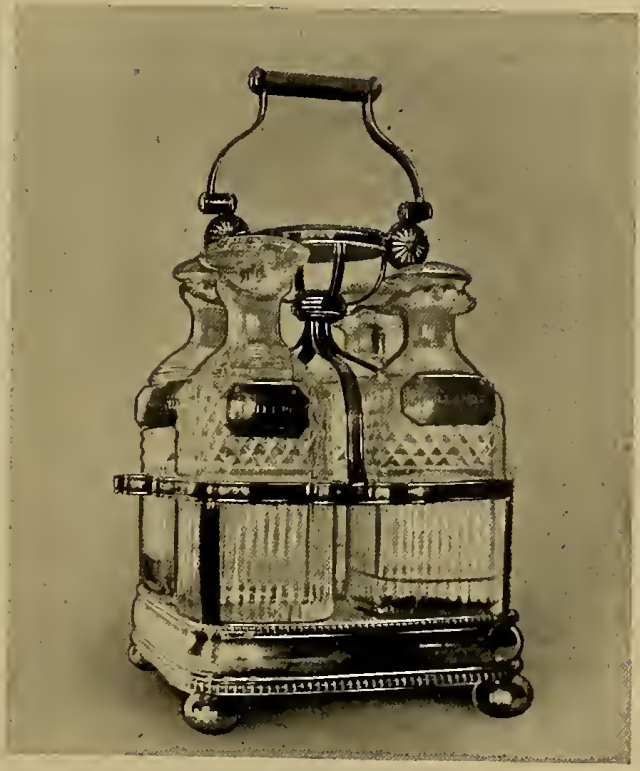

LIQUOR-FRAME (I8ro) 

which give an important clue to the dates of their manufacture. The handle-socket and bead-work on the coffeepot, being stamped from plated metal, show this piece to be considerably earlier than the sauce-boat, which has similar edges and mounts of thin silver.

The exchanging of only fairly good specimens for better ones is always necessary in the earlier stages of acquiring a first-class collection; for not only is it impossible to find the best all at once, but the collector's discriminating power is a matter of growth. The specimens that are finally discarded are few, on the whole, and they serve a very useful purpose. Rare things, moreover, are almost invariably expensive, and to buy such judiciously one must have experience.

Fortunately for the beginner, there are always available such pieces as those of our early purchases illustrated on the preceding page. They are excellent of their kind, but being of a type not very much in demand, can easily be found and purchased at moderate prices. If in good condition, these articles are worthy of a place in any collection, and furnish material for considerable study.

The simple dish-stand was the first thing we purchased from our old friend the curio-dealer. If glass dishes either oval or round can be found to fit these stands, they are not unattractive. They are cheap because practically no one uses them. The toast-rack and salad-cruet, while neither rare nor expensive, are good examples, and prove their usefulness daily. The bottle-stand, with the original cut-glass bottles and plated labels, has unfortunately lost its sugarbasin, which probably disappeared when custom decreed that it should no longer be used. 


\section{III}

\section{THE SMALL ARTICLES THAT WERE MADE FIRST}

$7 \mathrm{HE}$ original intention when the first additions were

1 made to our collection was merely to get together a number of attractive pieces for regular household use or decoration; but we soon became interested in the subject from a historical point of view, and though it was difficult at that time to get any extensive information concerning the development of the industry, we obtained what knowledge we could from various sources, and then began searching for some of the small pieces that represent the earliest attempts.

It is generally known that Sheffield Plate is silver plated on copper, and by many people the simple fact of a copper foundation is supposed to be a guarantee of genuineness. Perhaps a few facts about the history of the process may show more clearly what Sheffield Plate, properly speaking, really is.

The story of the discovery by a Sheffield cutler named Thomas Boulsover, that silver and copper when fused together could be worked as one metal, has been variously told. There is no question, however, about the fact that he rolled an ingot of the combined metals into a flat sheet, and from this made small articles of plated ware. 
Plate ViII

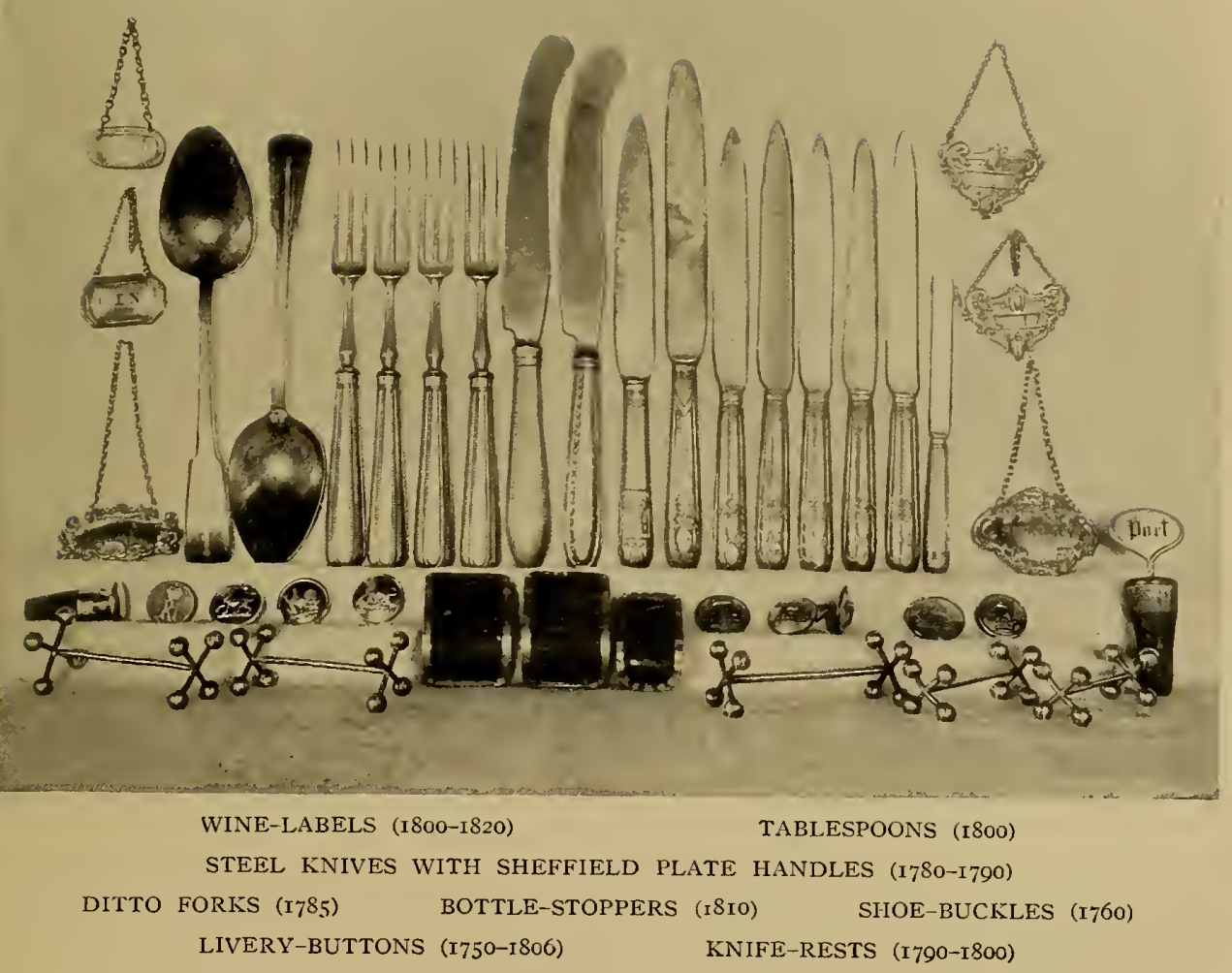



It is true that various methods of gilding and silvering the baser metals were known to the ancients, and have always been practised in various arts and crafts, but before Boulsover's discovery in I743 there was no sufficiently durable method for making tableware and articles of domestic use from a cheaper metal plated to look like solid silver. Accordingly people who could not afford silver were obliged to content themselves with pewter.

The tale is that while repairing a knife-handle in which silver and copper were both present, Boulsover noticed that after being fused together the two metals expanded equally in working. The idea occurred to him of covering a flat piece of copper with a thinner sheet of silver, heating the two together, and hammering this ingot into a thin sheet. $\mathrm{He}$ found as a result that he could produce a sheet of copper evenly coated on one side with silver of any desired thickness, and from such sheets he began to make plated goods in imitation of solid silver. Of necessity the plating was done before the article was made up, and the fashioning was diffcult; but as the price of silver bullion was many times what it is to-day, the making of plated ware became very profitable, and the industry developed very rapidly in Sheffield. At first, however, the invention was applied only to small articles such as buttons and boxes. Boulsover himself began by making buttons.

We were lucky enough to find a few old plated livery buttons, and several of them were marked with the name and address of a London firm which proved to be still in existence. On calling at their offices, I was interested to learn that the methods first employed have never been altered, and that these buttons are still stamped out to-day from rolled plate 
in practically the same way, and sometimes from the same dies, as silver ones in the time of Queen Anne. This is the only branch of the Sheffield plating industry that has not been supplanted by the modern process of electro-plating, by which the article is plated after it is made up.

I was presented with several buttons in various stages of construction, which illustrate the method used for both silver and plated ones. The face of the button is stamped from a small sheet of metal in a steel die. It is then cut to the shape, and the edges are rolled back over a foundation, usually of brass, to which the shank has been hard-soldered.

As large quantities of these buttons are still made for liveries and uniforms, they are easily obtainable. Quite the reverse is true of other small articles, which are rare and difficult to find, because comparatively few of them were made, and of those not many have stood the wear and tear of a century and a half. From a silversmith in London, who has written an instructive little book on the subject, we obtained some of the knives and wine-labels, together with much useful information which he had gained during a long experience and was always ready to impart. To him we owe the greater part of our collection of spoons and sugar-tongs, which have come along one or two at a time at infrequent intervals. These odd bits sometimes turn up unexpectedly in most unusual places.

It is easy to see how knife- and fork-handles were made by the method originally employed in making silver ones; namely, by stamping the halves and soldering them together, after which they were filled with a substance resembling resin; but in the case of sugar-tongs and teaspoons, the problem of keeping only the silver in evidence must have been 
Plate IX
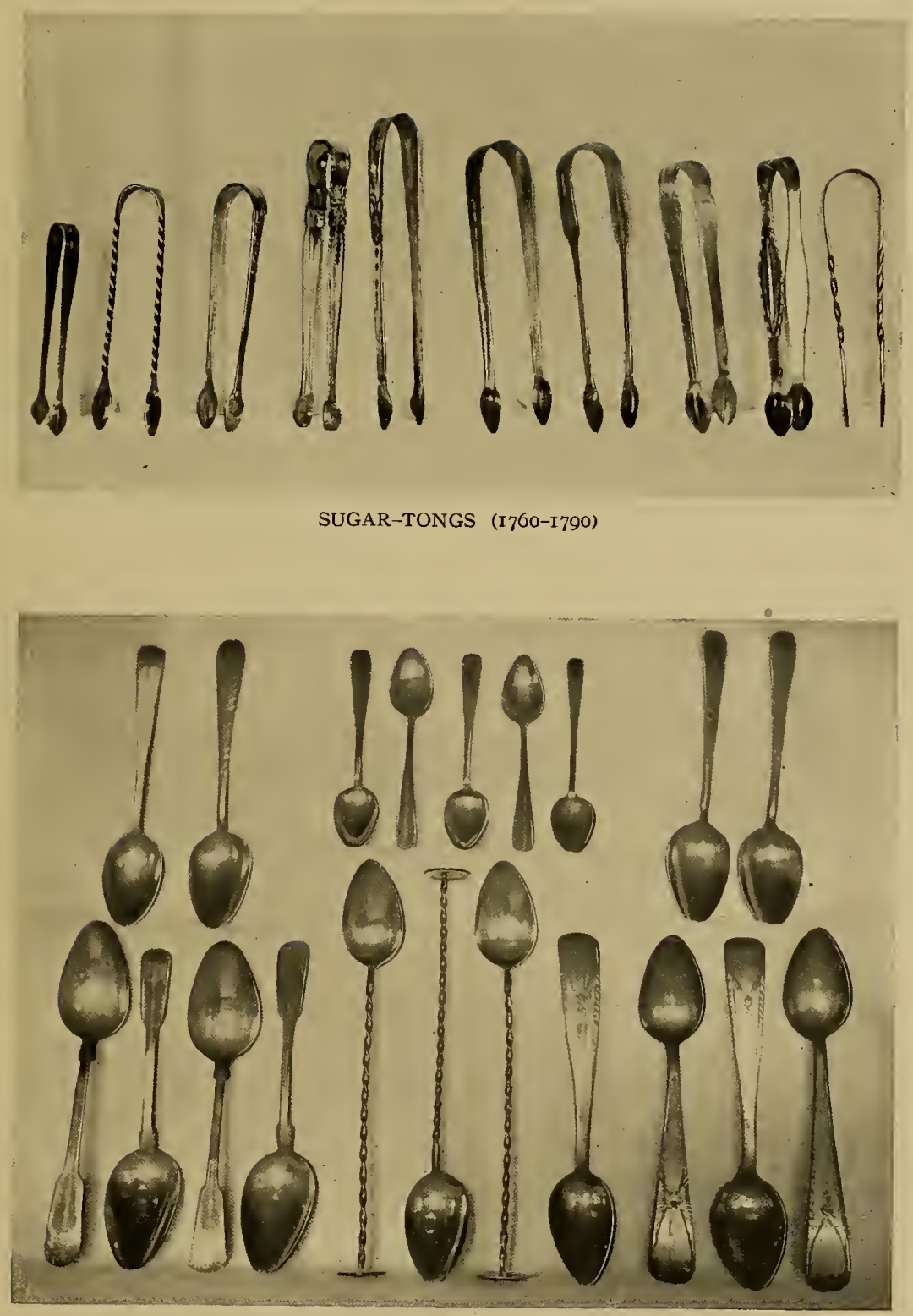

TEASPOONS, COFFEE-SPOONS AND SUGAR-CRUSHERS (I770-I780) 

Plate X
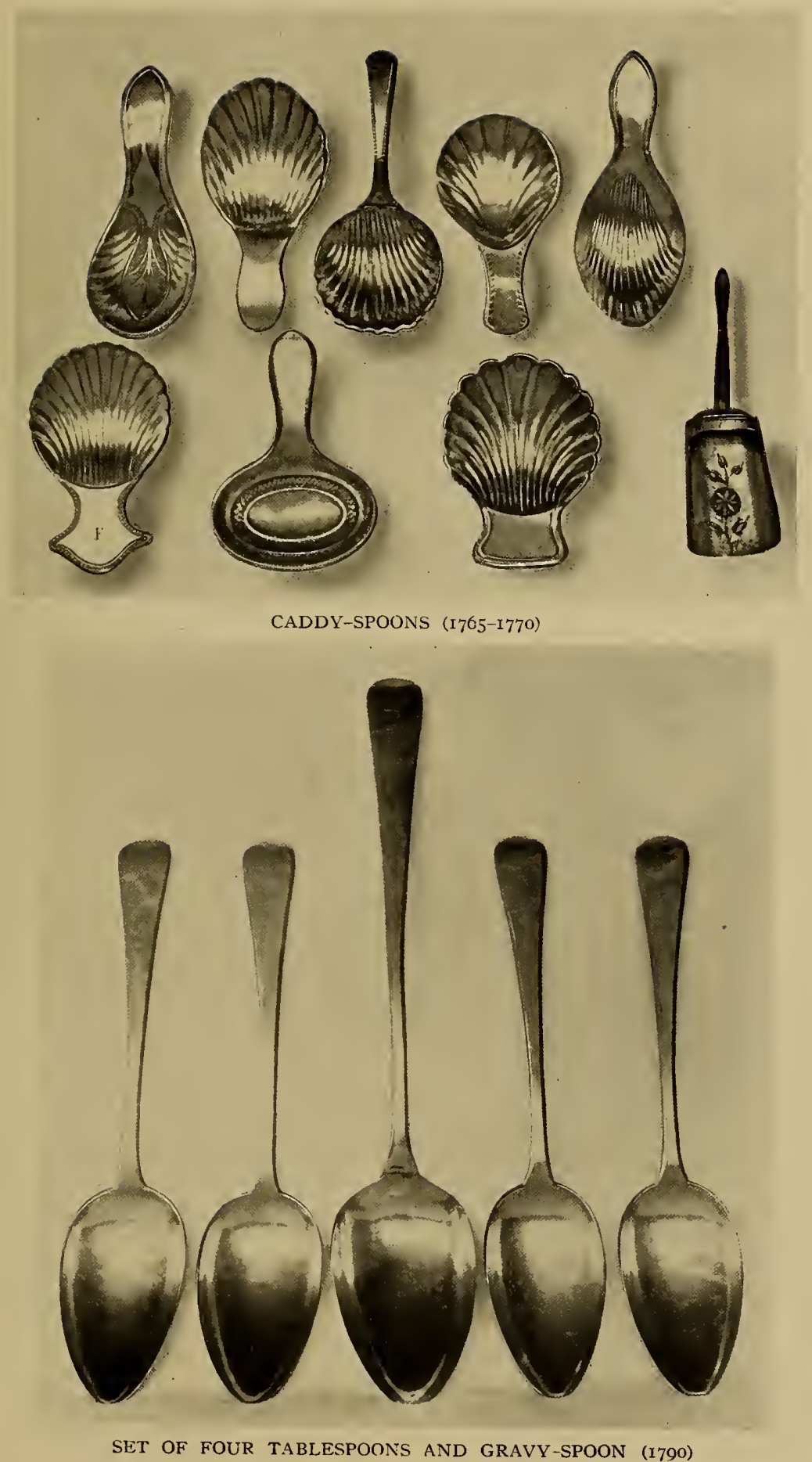

most difficult. However, these were so skilfully done that even in the much-worn specimens it is not too easy to detect how the article has been put together.

Caddy-spoons were the simplest, for they could be stamped in one piece from two sheets of plate placed back to back and soldered together, and most of them were done in that way. Whatever silvering or tinning concealed the copper on the cut edges has long since worn off, though otherwise many of these caddy-spoons are in perfect condition.

The sugar-tongs and the shanks of spoons, ladles, etc., are usually formed of a plated wire, flattened into the right shape and often chased. A white streak down the centre of a worn spoon-handle or on the inside of the tongs shows where the edges of the flat sheet were joined to form the wire. This streak can be seen on almost every specimen.

The three spoons, with their long twisted handles and flat disks for crushing the hard loaf sugar in the toddy-glass, are interesting examples of an article which has become obsolete, owing to the altered habits of a later generation. Sugarcrushers were not infrequently made in silver, but these three are the only ones I have ever happened to see in Sheffield Plate. They are in excellent condition, which is exceptional, for most of the spoons were very flimsy, and it is not surprising that the makers soon turned their attention from such small wares to the larger pieces where the amount of silver saved was sufficient to compensate for the additional labor and skill required in the fashioning.

Ladles and fish slices, being on a larger scale than the forks and spoons, appear to have competed more successfully with the silver ones, for their manufacture evidently continued for a long period. 
They furnish an instructive illustration of both early and late methods used in dealing with the serious problem of concealing the copper edges. At first any edges that could not be turned over, as in the case of buttons, were simply tinned, or perhaps lightly silvered by some one of the processes previously used; but in 1785 a method was invented by which the cut edges were covered by a hollow silver wire soldered on. The bowls of the two plain soup-ladles with ivory handles show this silver-threaded edge, which has recently come to be regarded as such an infallible sign of genuineness that it is now added to many of the fakes.

A later and better method is illustrated by the two plainer fish slices. In this case a solid silver wire was hard-soldered round the cut edge, and the whole slightly bevelled off with the hammer so that no joining was visible. When the blade is slightly tarnished, this strip can be perceived by the slight difference in color. The ends of the asparagus-tongs, which are made of flattened wire like the sugar-tongs, are finished in this manner.

The fluted toddy-ladle with black wooden handle was found in a tiny shop in Rouen. It was the first piece of French Sheffield Plate acquired. Compared with the English ones it is light and flimsy. This is often the case with pieces made in France, where considerable plated ware was produced after the invention had proved successful in England. 
Plate XI

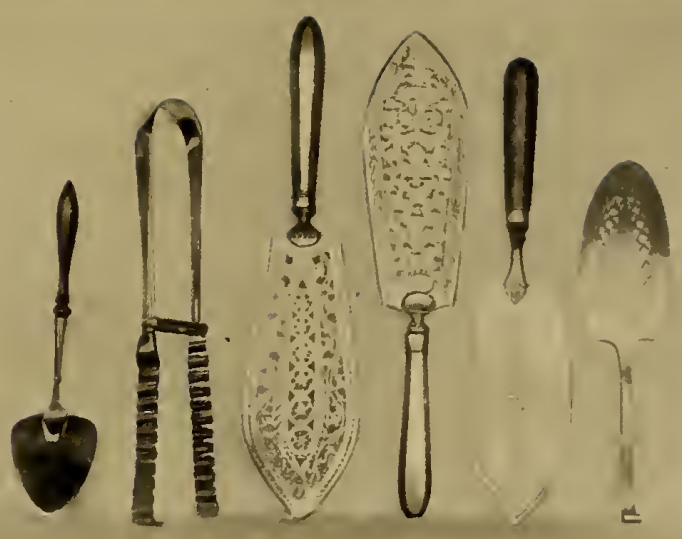

GROUP OF FISH SLICES AND ASPARAGUS-TONGS (I $780-18 \mathrm{CO})$

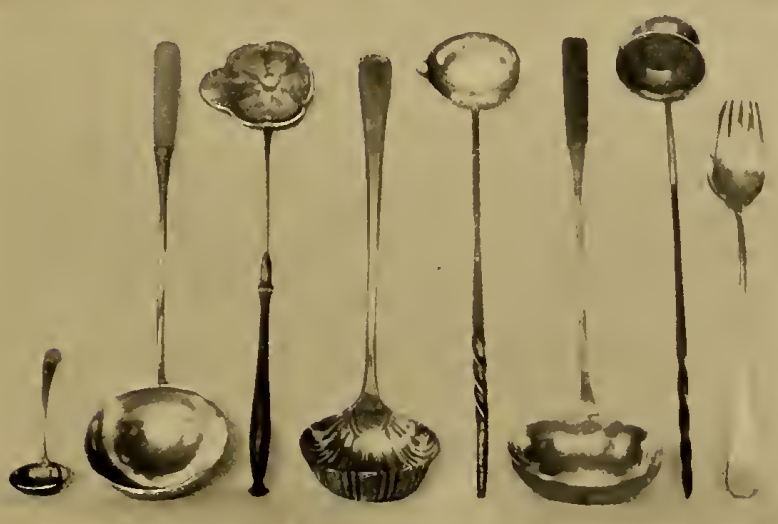

TUM BLER-LADLE (I780)

SOUP-LADLE WITH IVORY HANDLE (I795)

TODDY-LADLE (FRENCH) (I8O0)

SOUP-LADLE WITH FLUTED BOWVL (I784)

By Nathaniel Smith \& Co.

TODDY-LADLE WITH BONE HANDLE (I 780 )

SOUP-LADLE WITH IVORY HANDLE (1795)

TODDY-LADLE WITH BONE HANDLE (I780)

SALAD-FORK (I780) 



\section{IV}

\section{EARLY PIECES OF HOLLOW WARE}

W

HILE Boulsover, who at first kept his process a secret, was very successful with buttons and other small wares, Joseph Hancock appears to have been the first to foresee the advantages of applying the invention to larger articles. His first productions were copper sauce-pans, plated with silver on the inside.

It is still one of our unsatisfied ambitions to possess one of these sauce-pans made by Joseph Hancock. We know of the existence of one or two, and I have a firm belief that a few others have been preserved somewhere. Hancock also made teapots and other articles of tableware and marked them, but we never have come across a piece with his name on it.

It is a curious fact that Boulsover, after making large profits from his buttons, etc., abandoned their manufacture and built a mill where he made saws and various edged tools; and that Hancock also gave up making plated ware and devoted himself exclusively to rolling the plate. This was first done by hand, then by horse and water power, and finally by steam. The fact that Hancock finally owned large rolling mills from which he supplied raw material to the trade shows how rapidly the industry had grown during his time. 
The first really early piece of hollow ware that we succeeded in obtaining was a rather prosaic little tankard. The manner of its purchase was somewhat amusing. Seeing the piece in a small shop window, I at once determined to have it; and with the beginner's enthusiasm for knowing the history of every acquisition, I asked the shopkeeper if he knew where it came from. He replied in a caustic manner that he did not. Not having the requisite amount in my purse, I promised to call for the tankard later, but on doing so was told that the price was double what I had been asked previously, and also that the article was not for sale. The shopkeeper declined to give any reason for his extraordinary conduct or to sell the tankard at any price whatever. I left the place, vainly attempting to cover my disappointment by a show of indifference, and called upon the dealer in an adjoining street who had sold us our first teapot. He undertook to buy the tankard for us, and did so at the advanced price. He discovered that the reason for its withdrawal had been my question where it had been obtained, which was interpreted as a reflection on the honesty of the seller.

Not long afterward we obtained a similar tankard bearing the mark of Daniel Holy, Wilkinson \& Co. with their symbol, a long pipe. Although thousands of these tankards were made, they were usually the property of hotels or inns, and most of them have disappeared as a result of long and exceptionally hard usage. When intended for public use they were exact measures, and were often marked to indicate the quantity contained.

As the tankards illustrate the manner in which from time immemorial hand-wrought articles of hollow ware have been shaped, as well as some of the new problems that con- 
Plate XII

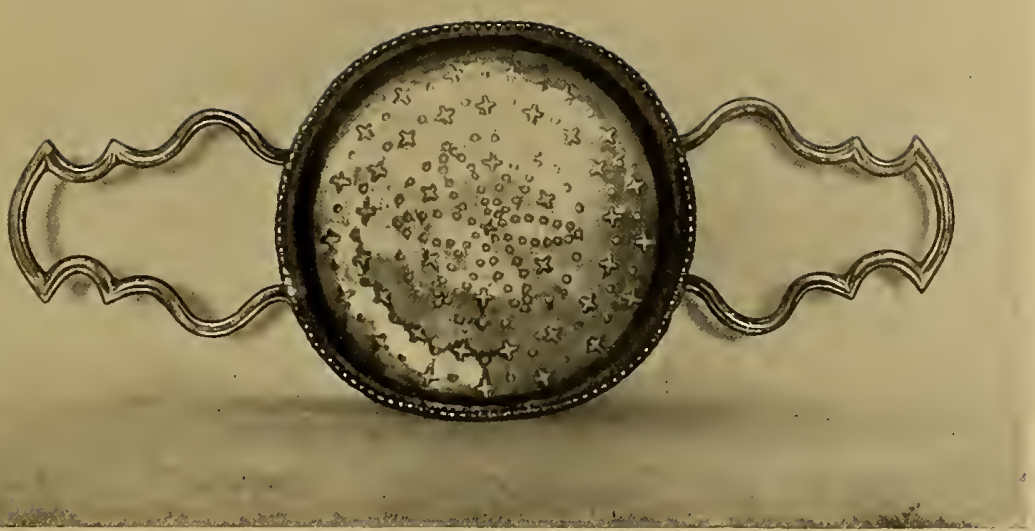

LEMON STRAINER (I760)

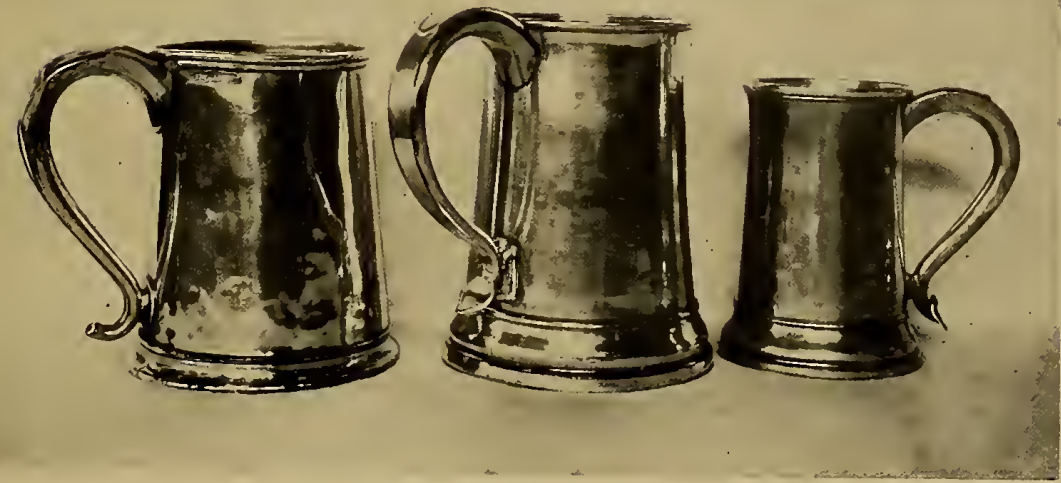

PLAIN PINT TANKARD ( 1780 ), (Marked. See Plate L)

DITTO, UNMARKED (1785) HALF-PINT DITTO (1785) 

fronted the first artisans who essayed to produce them in plated ware, let us examine the process by which the plain covered tankard was evolved.

The workman naturally took his design from the silver ones of the period, and using the same tools, employed as far as possible the same methods. For the shaping or "raising," he had a leather cushion filled with sand, and steel stakes of varying sizes and shapes on which to rest the article as it was being hammered. His tools were wooden mallets and a great variety of polished steel hammers. Resting a flat sheet of the right size on the sand cushion, he would gradually hollow the centre by repeated blows; then, holding it over a round stake, bring up the edges till he had first a shallow bowl, and finally a deep vessel.

For very deep articles it was necessary to join one or more pieces into the form of a tube or cone before raising. This was done with hard solder (silver containing more than the usual amount of alloy). The seams were often dovetailed. After being soldered, they were hammered until all trace of joining had disappeared. This, of course, was far more diffcult with the plated sheet than with the solid silver, as the copper was so easily exposed in the heating.

As this tankard is plated both outside and inside, it was necessary to place two sheets of plated metal back to back. On the outside the dovetailed seam comes under the handlesockets where it is least likely to be seen, but the one on the inside is in a different place, showing that lining and outside were cut out and joined up separately.

After the seams were soldered, the piece was placed on a stake and the whole surface hammered over to harden the metal. Then the article was raised into its final form. The 
hammer marks in regular rows are visible both outside and inside. To form the plain rim, the upper edge is turned back and rolled over a ring of hard metal. The ornamental band round the middle is a separate piece soft-soldered on.

The foot of the tankard, like the lid, is raised from a circular piece, possibly with the aid of a die. The edges are brought over a circular plinth of mahogany which forms the base. The edge of the lid is turned under, and secures the under portion called the bizzle.

The box-handle is a hollow tube hammered into the right shape, and finished at the bottom with a heart-shaped piece made of two sheets placed back to back, the edge of the outer one being turned over.

The hinge and its mount are made from small pieces of the rolled plate, partly with the aid of dies. They are joined with soft solder to the handle, which is fixed to the body of the tankard in the same way. The workman had to be very discriminating in the use of hard and soft solder, for the former requires such great heat to melt it that it cannot be safely used after the article has been hammered into its final form, while the soft solder, being largely composed of lead, will melt at a comparatively low temperature. It is for this reason that one so of ten sees old Sheffield teapots whose spouts or handles have been accidentally melted off.

Our tankard has an interesting mark; the written letters $\mathcal{L} \mathcal{L}$ in a small shield being repeated three times on the lid, in such a way as to resemble the hall-mark used on silver. On the body of the tankard is the additional mark LAW indicating Thomas Law, one of the early Sheffield makers.

The two-handled cups, sometimes called porringers, sometimes tankards, also have marks resembling hall-marks. 
Plate XIII
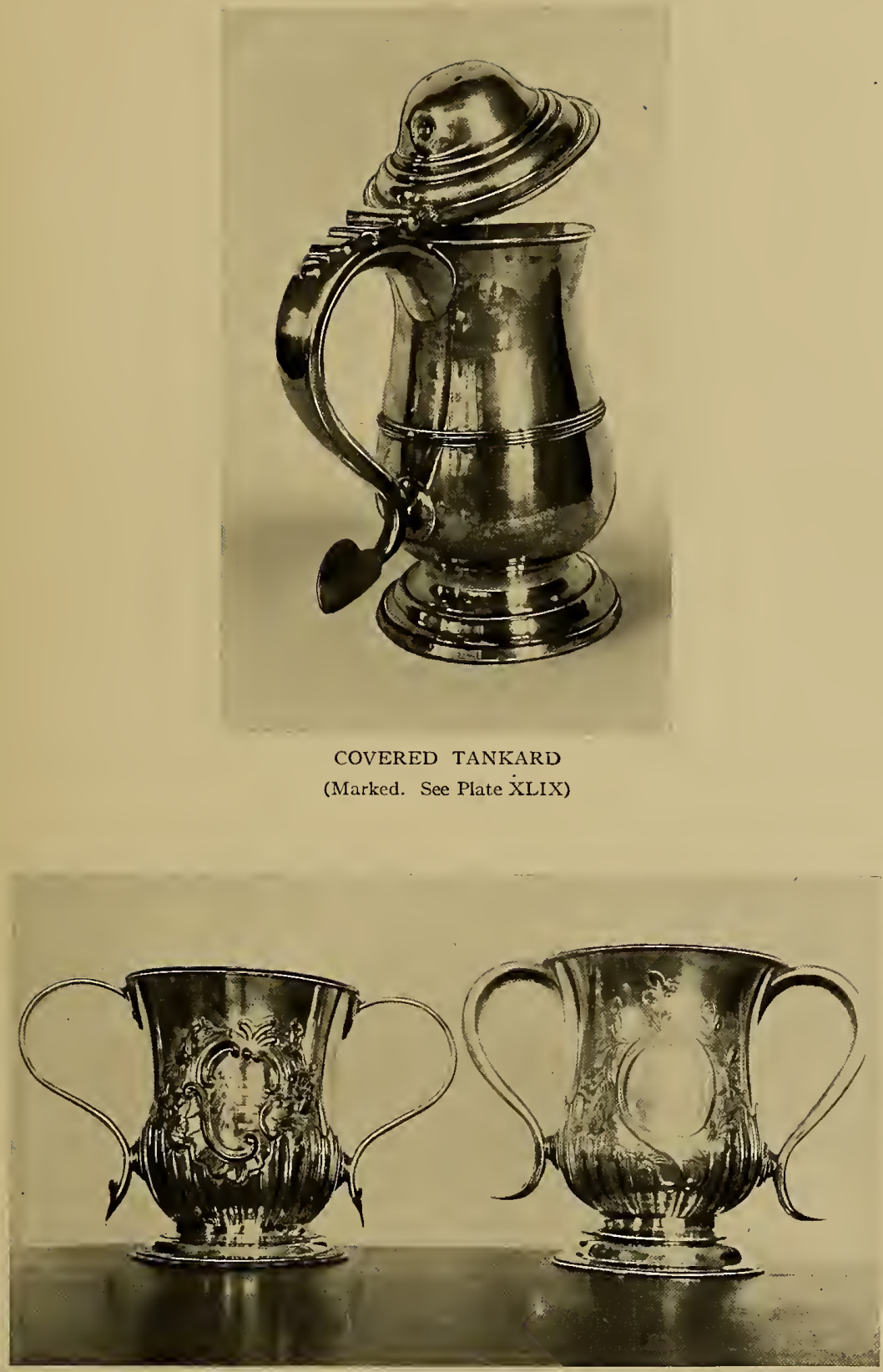

TWO-HANDLED CUPS WITH GEORGE II CHASING (I765) (Marked. See Plate XLIX) 

These two pieces are fine specimens of early workmanship. The method of construction is identical with that of the covered tankard.

One of these has box-handles; those on the other are struck from dies in two pieces, soldered together and filled like knife-handles. The bases are of double metal, and there is no wooden plinth.

The embossing is of a type that became very popular in the time of George II and is often described as "George II chasing." After the design was outlined, the article was held over a narrow steel stake called a snarling-iron, and by repeated blows of a small hammer, while the article was moved over the stake following the lines of the pattern, the design was brought into high relief. Then the whole interior was filled with pitch to give it rigidity, and resting the article on a sand cushion the workman finished it in detail with his chasing tools. Here is another instance where the skill of the workman in rolled plate was severely taxed, for if he allowed the copper to break through the silver surface, his work was ruined.

However, high-relief chasing was a favorite form of decoration for both silver and plated ware, and many of the most characteristic pieces of early Sheffield Plate are decorated with this elaborate George II chasing, which, however, should not be confused with the similar ornamentation of the Victorian period, of which more will be said later.

One of the few specimens that we have purchased in Sheffield is the pitcher or jug of Adam design. Both that and the quaint sauce-boat are excellent examples of early workmanship. The body of the sauce-boat is raised from the flat in one piece, that of the jug is raised in two pieces, 
each with a seam at the back. The dainty ornamental band on the jug answers the double purpose of decoration and concealment of the seam where upper and lower parts are joined. The foot is hand-raised, with the beaded portion die-struck. Handle-sockets and knob are struck in halves from dies. The upper edge of the body is covered with a beaded band, folded over and soldered on. The same method is followed in the case of the gadroon mount which covers the edge of the sauce-boat. The one on the foot is made from the same stamping, simply soldered on to the outside. It has a bit of plain edge left on, which is turned under to secure the flat sheet which forms the bottom. The curious box-handle is finished at the top with a leaf-shaped mount, struck in halves, which are hard-soldered together and then soft-soldered to the handle. The handle-socket is die-struck, and attached to both handle and body with soft solder.

By a curious coincidence, this sauce-boat and the one illustrated in the preceding chapter were purchased in different places the same week. The same is true of the two-handled tankards, one of which we found in London, the other in Liverpool. 
Plate XIV

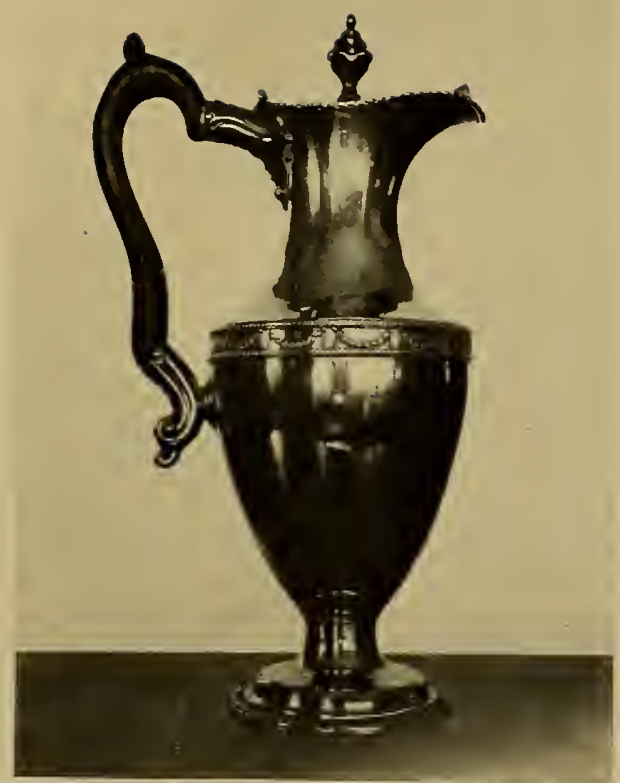

CLARET-JUG IN ADAM STYLE (I777)

By Matthew Fenton

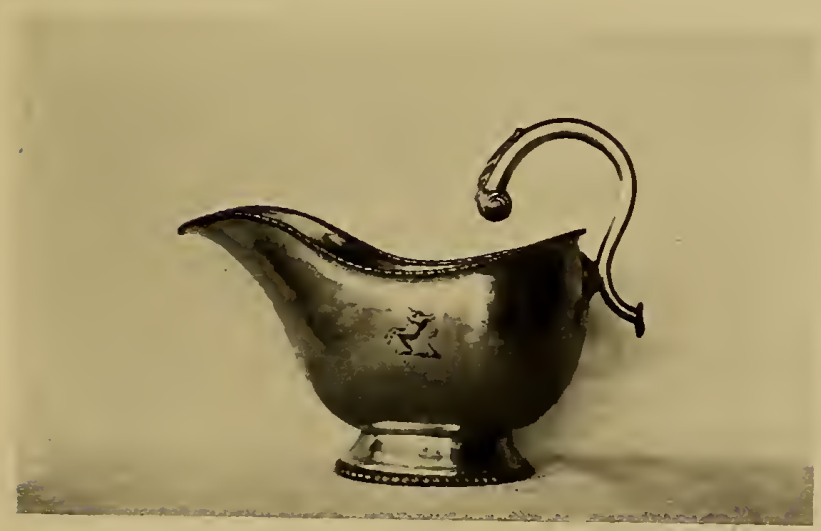

"QUEEN ANNE" SAUCE-BOAT WITH GADROON EDGES OF ROLLED PLATE (NOT SILVER) (1765) 



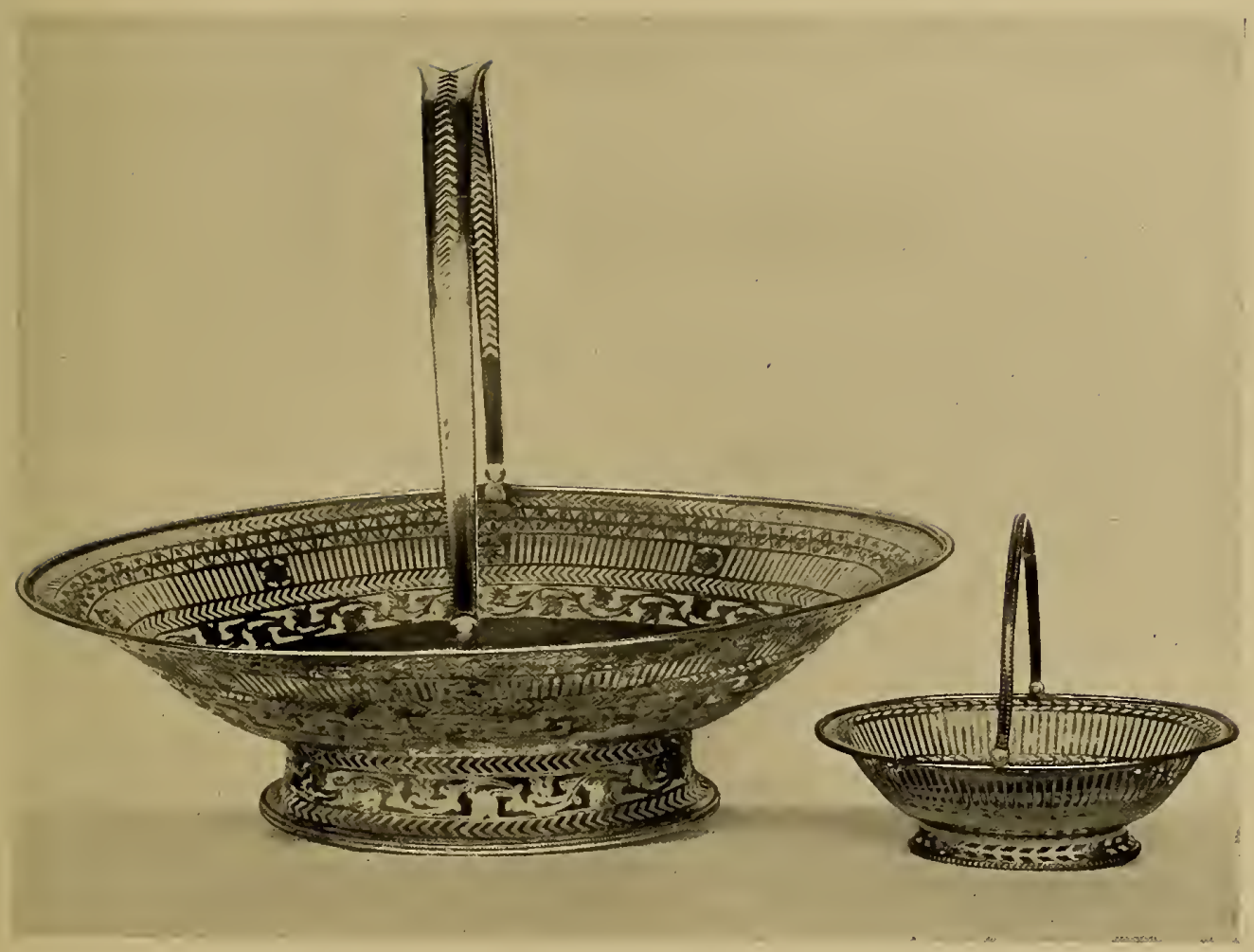

PIERCED AND CHASED CAKE-BASKET (I780). By Nathaniel Smith \& Co. SWEET-BASKET (I783). By J. Young \& Co. 



\section{V \\ A FEW PIERCED AND CHASED PIECES}

$A$ the Sheffield plating industry was carried on for a tinually changing, it followed that the plated ware, like the furniture, was made in a great variety of styles, and the buyer to-day has a wide range of choice in the kind of specimens he may search for, though it may be quite a different matter to find them.

To many collectors the pierced and chased pieces are the most fascinating of all, and I well remember our delight when we acquired our first fine specimen. It was the oval cake-basket shown in the preceding illustration, and I have never seen it excelled anywhere. The price was high, and for that reason the dealer from whom we bought it had had it in stock for some time. He was so greatly pleased with us for choosing it at once that he has never failed to send us on approbation any exceptionally fine pieces that have since come into his possession. One of the treasures which he sent us a year or two later is the tiny sweet-basket which forms such a fitting companion to the other. The miniature baskets are far more rare than fine cake-baskets, but a collector is fortunate indeed to find a specimen of either in good condition. 
For many years before the invention of Sheffield plating, piercing had been used as a form of decoration for silverware, and the beautiful pierced and chased pieces made by Paul Lamerie a quarter of a century earlier must have furnished inspiration to the Sheffield platers; but they had to invent a new method and adapt their designs to it. This they did so well that both method and designs were adopted for silver as well as plated ware, and to this day they have never needed to be improved upon. The process is an ingenious one, and the old machines are still used in Sheffield for punching out open-work designs in modern silver and plated ware. The old silversmiths had always cut out the pattern with a fret saw, but this could not be done in the case of plated metal without exposing the copper on the cut edges. To avoid this a totally different plan was adopted. The reader has doubtless noticed in the case of paper that has been perforated by machinery that the cut edges are curved inwards by the sudden blow. In the same way it was found that by striking a piece of flat fused-plate with a heavy punch the silver was dragged over the copper on the cut edges. By placing underneath the article a bed cut so that the punch exactly fitted into it, it was possible to pierce holes of any desired shape in such a way that the silver on the upper and under surfaces stretched over until they met and completely covered the copper. It will be seen that by repeating the same perforations in different ways, a great variety of patterns could be produced. Sometimes the little chased patterns which accompany the pierced work were stamped in the same machine, giving much lighter blows with tiny punches that resembled the tools used for chasing by hand.

I have referred in the preceding chapter to the chasing in 


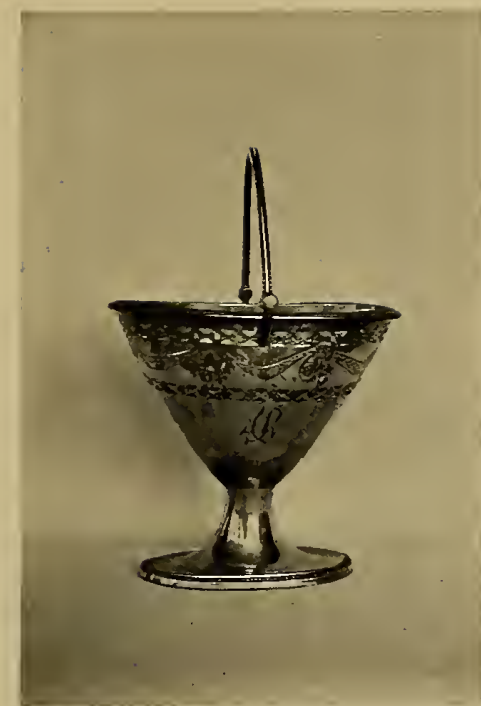

Plate XVI

PIERCED AND CHASED SUGAR-BASKET

WITH BEAD EDGES (I 780 )

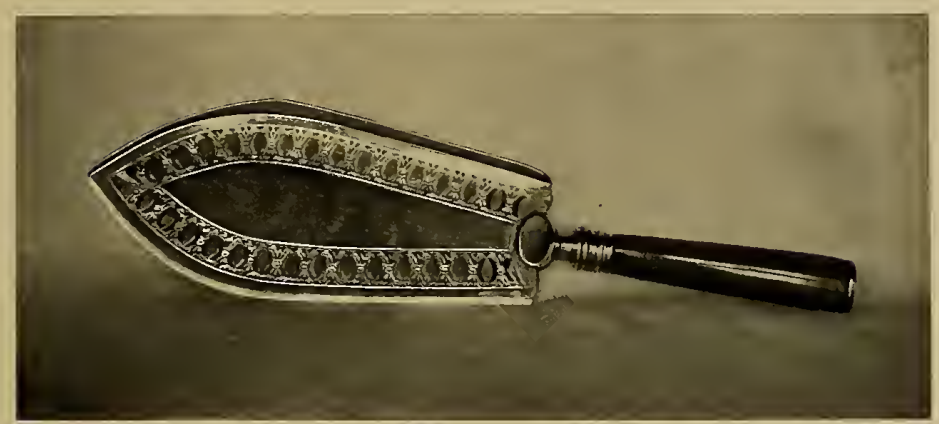

PIERCED AND CHASED FISH-SLICE WITH SILVER EDGES AND IVORY HANDLE (I788)

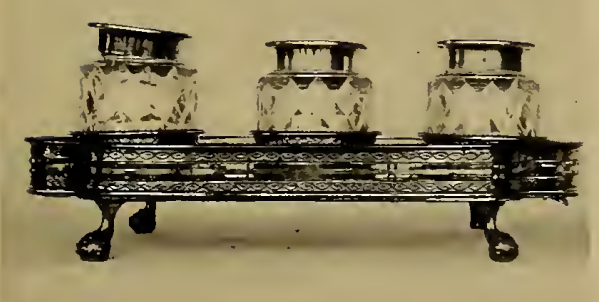

PIERCED AND CHASED INKSTAND WITH CUT-GLASS BOTTLES ( 1785 )

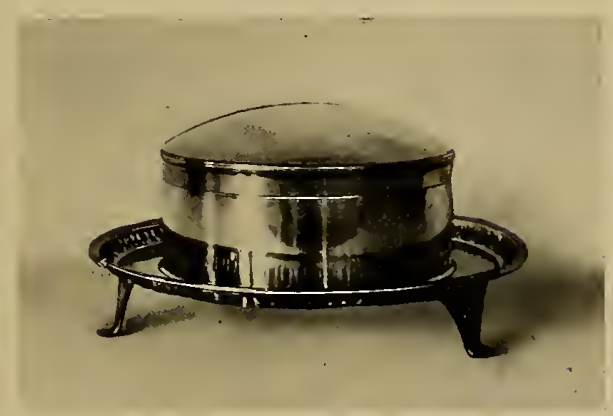

BISCUIT-BOX ON PIERCED AND CHASED STAND (I790) 

A FEW PIERCED AND CHASED PIECES 23

high relief which was a favorite form of decoration during the earlier period. At first the chased or pressed patterns that were combined with piercing were of a somewhat repoussé character, but they gradually became less raised until the form prevalent about 1780 very closely resembled bright engraving.

After the Sheffield platers had found that slight taps of a hammer upon their chasing tools would produce tiny dents which could hardly be distinguished from the cuts made by an engraving tool, but without risk of breaking through the silver surface, it was only another step to combine this process with the piercing in the stamping machine, the same little patterns being indefinitely repeated.

Most specimens of pierced and chased work that have survived the ravages of time are of this character. They would perhaps be more appropriately described as "pierced and pressed" or "pierced and stamped." They have an unmistakable character that is all their own, and their unusual quality is so appealing that they were in great demand from the very first. The invention of a machine for producing these delicate pieces was the means of greatly advancing the plating industry.

Considering their fragile nature it seems wonderful that any specimens of pierced and chased work can be found to-day in good preservation, but the few that remain are well worth the trouble it usually takes to find them. I have never seen a genuine old piece of this description that was not fascinating for its daintiness of both form and decoration. Many a time have we come across the remains of a beautiful piece, hopelessly out of condition, only to add to our despair of ever finding a perfect specimen. 
It was only after a long search that I accidentally discovered this boat-shaped cruet while on a visit in the South of England. On returning home I was greatly surprised to see the oval one which my husband had been lucky enough to secure during my absence. This was another instance of the uncanny way in which so many of our treasures have come to us in pairs, or rather in twos, from widely separated sources.

The two cruets are equally fine examples of the two prevailing types. It will be noticed that while the bodies are quite different in shape the cut-glass bottles are of the same design and could be used interchangeably. Very probably the makers of the two cruets purchased their glassware from the same firm. 


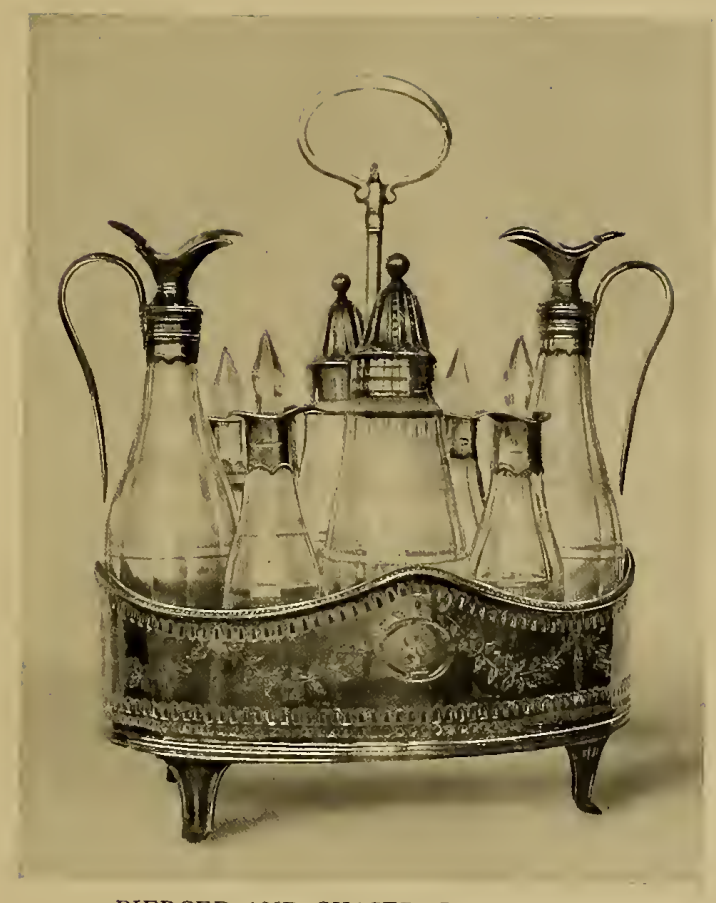

Plate XVII

PIERCED AND CHASED CRUET (1775)

By Daniel Holy, Wilkinson \& Co.

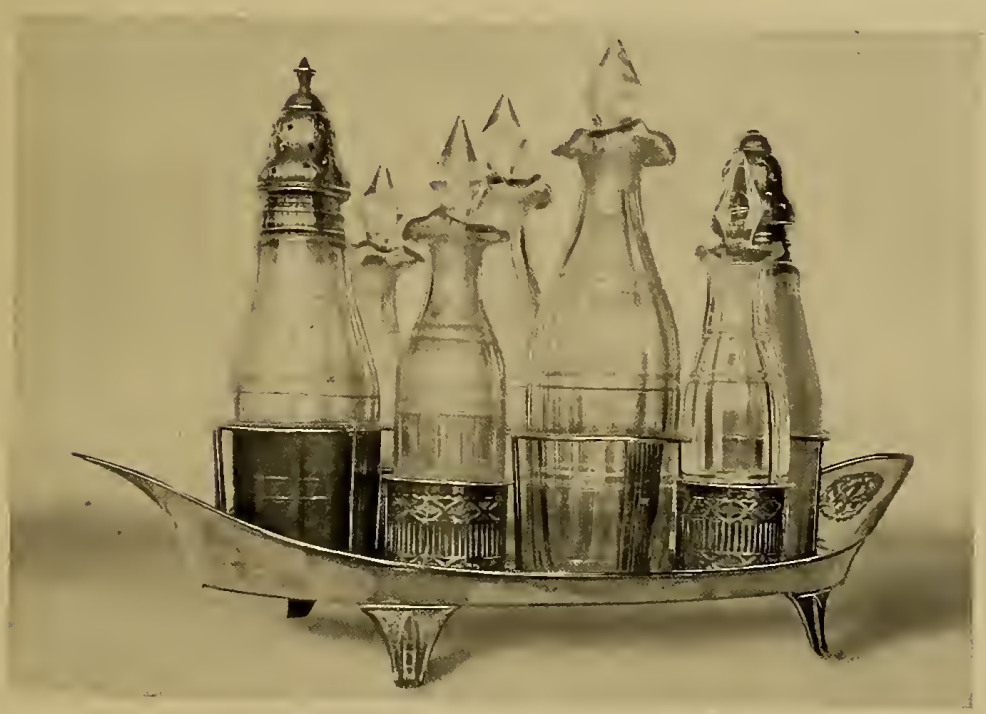

PIERCED AND CHASED CRUET (1780)

By Richard Morton \& Co. 



\section{VI \\ WIRE-WORK}

$\mathrm{O}$

NE might well suppose that when the Sheffield platers had succeeded in imitating so perfectly the pierced and engraved work of the silversmiths, they had finally brought their art to its greatest perfection, but I have still to describe what is said to be the most difficult achievement of all, namely the wire-work. Of course pieces of plated wire of one kind or another had been used from the first for small portions of solid pieces, such as handles, rings, etc., but the term "wire-work" is applied to such articles as baskets, toast-racks or centrepieces made wholly or largely of wire in twisted or interlaced patterns.

Equally delicate in design and construction with the pierced and chased pieces that harmonized so well with the beautiful furniture of the Heppelwhite and Sheraton periods, the wire-work was an equally fitting accompaniment, and the choice between these two styles by those who wished particularly decorative plated ware must have been exceedingly difficult.

The handsomest piece of wire-work in our collection is the large epergne. It is a perfect specimen wholly fashioned of shaped and reeded wire of varying sizes, and is typical of the simply designed but elaborately constructed centre- 
pieces which were considered necessary to every elegant dinner-table in the latter part of the eighteenth century.

The epergne stands thirty inches high, and the baskets may be filled with fruit and sweetmeats as originally intended, or with flowers, which would appeal more to most of us at the present time. Sometimes the baskets had glass liners, but the effect was rather heavy and I fancy most of the wire-work ones never had any.

Light as it appears, this piece is substantially made, and will support considerable weight. As may be seen from the illustration the heavier portions are of thick flat wire, simply decorated with reeding through the centre. The shaped wire used in the base and baskets is flat on the inside and threesided or bevelled on the outside, these bevelled wires varying in size according to the size of the basket or portion of the epergne where they are used. The three feet are from flat stampings and have reeded edges. The outer and inner portions are soldered together and filled.

Wire-work, like pierced and chased work, owed its great popularity to an invention of the platers which made it possible to produce the goods at a reasonable price. There were several methods invented for making plated wire. The first was patented in $\mathrm{I} 768$ by a Birmingham plater named Whateley. He made copper wire plated with silver, silver wire plated with gold, and he finally plated gold on copper wire that had already been silver-plated. The various methods differed in detail, but they all started with a round bar previously plated. This was drawn through whortles of the desired shape, graduated from larger to smaller, till it acquired the right degree of thinness. These wires were round, square, hexagonal, flat, or reeded, for the purposes 
Plate XVIII

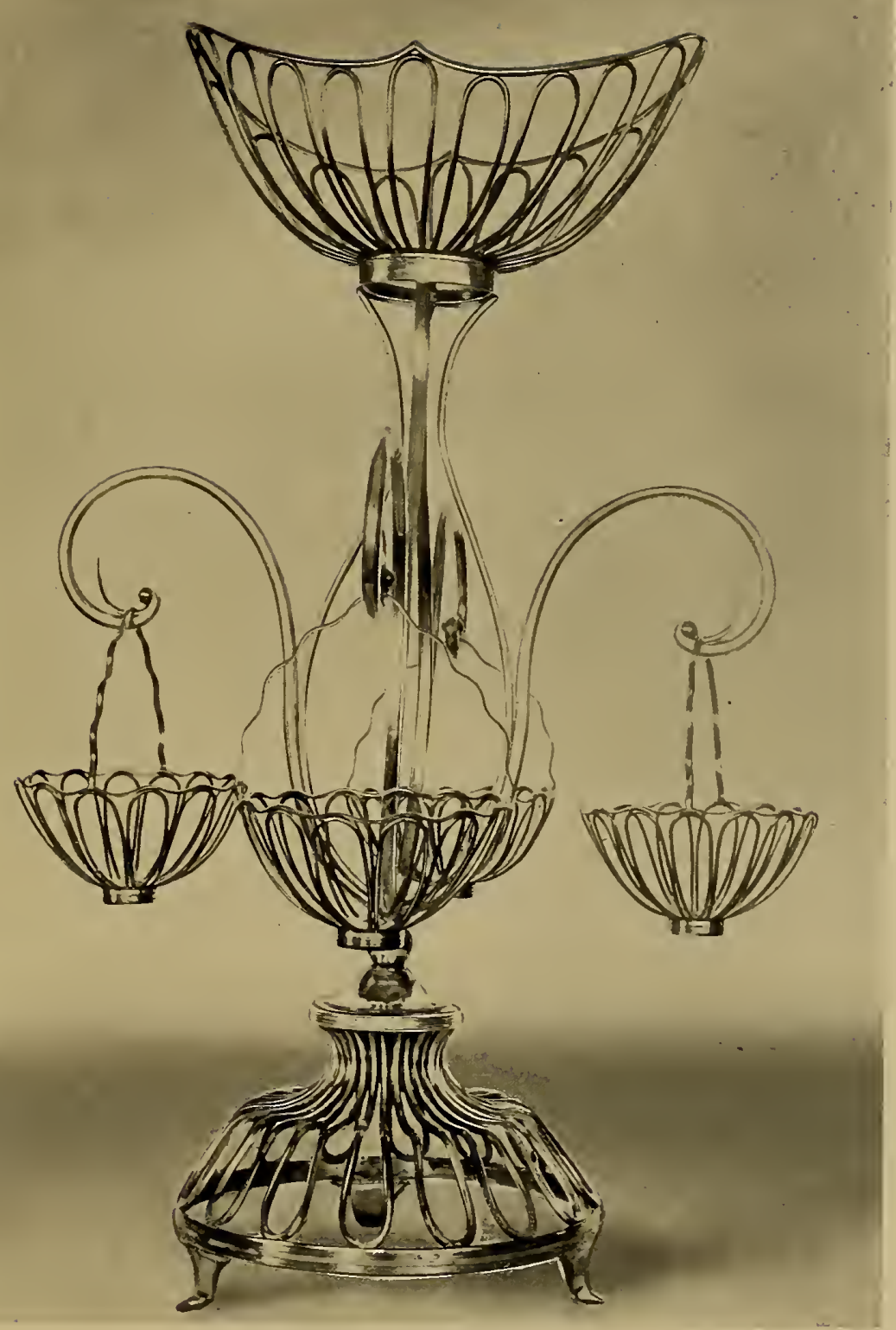

WIRE-WORK EPERGNE (I790)

Height 25 inches 

of the Sheffield Plate makers. By the same process gold and silver plated wire were drawn to fine threads for weaving, and extensively used for lace, fringe, and tinsel.

Old wire-work was always characterized by fine workmanship, and the platers executed many original and attractive designs in this fascinating material. Possibly some of these wire-work pieces may have furnished the inspiration for the cream-colored Wedgwood ware in which similar designs were carried out during the same period.

The expanding toast-rack is marked "R. C. \& Co. Patent," indicating Roberts, Cadman \& Co., who were also the originators of the silver wire edge. This Samuel Roberts patented numerous devices, some of which were important improvements upon previous methods.

Sometimes wire-work was combined with plain metal or pierced work with a pleasing result. The cake-basket (Plate XIX) is one of the best examples. The plain portion is raised, the seams where the two pieces are joined being plainly visible just under the handle-sockets when the basket is slightly tarnished. (This can be seen in the illustration.) The bent wires are hard-soldered to this body, and softsoldered at the bottom between two plates. The inner one is domed and gilt and its edges are covered with a hollow wire, as in the case of the bowls of soup-ladles previously described. The handle is a large twisted wire. The gadroon edges, shell mounts, and circular rivet-heads are all delicate stampings of silver. The gadroon edge is slightly turned under on the outside to conceal the copper.

The tiny basket is of finely reeded wire. It has a flat handle chased with the feather-edge border which was a popular form of decoration for spoons and small wares 
about 1780 . For reasons of utility many pieces of wirework were fitted with liners of blue, ruby, or plain glass. Later on the glass became the more important item, and simple wire-work supports and holders were made to fit the elaborate cut-glass dishes.

The charming little sweet-dish holder is a beautiful specimen made throughout of reeded wire. The original dish may have been plain or cut glass, but when we bought the piece it had a very ugly boat-shaped one which was evidently not the original. The present one was made to fit, and being quite plain, with the right lines, it shows the beautiful curves of the wire-work to perfection.

We found in our search for specimens with colored glass liners that this is a favorite field for the producer of "modern reproductions," for these can easily be worked together in copper wire, and all defects of soldering and finish covered by the electro-plating process. Of course these copies (some of which are better than others) will not stand close scrutiny as regards workmanship, and the designs are usually far inferior to those of the carefully constructed old work. We saw many faked or doctored-up sugar-baskets before we discovered the really fine one illustrated. It has its original liner of blue glass, which in those days was colored with copper and not with cobalt. Copper-blue glass is dichroic, having a greenish cast when looked at in one direction, and a purple tinge in another.

The other piece, similarly constructed, has a blue glass liner and a fitted cover. The little lid at the top is also removable and there is a small tube through which a wick or tape may be passed. Originally a spirit lamp, it was offered to us as a sugar-basin. 


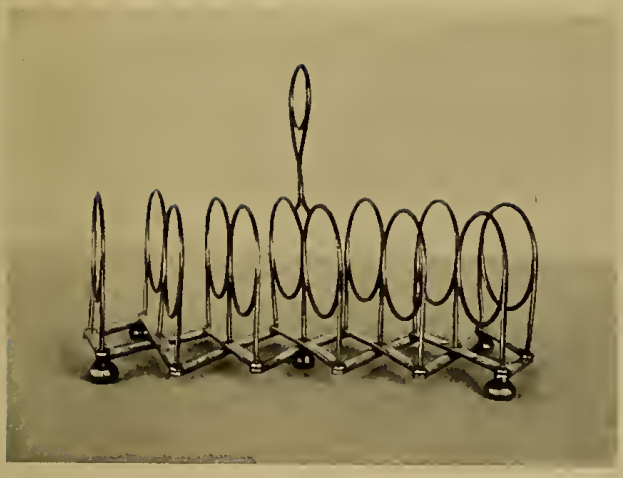

Upen

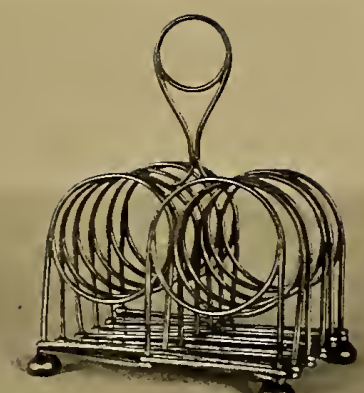

Closed

(See Mark, Plate L)

By Roberts, Cadman \& Co.

R. C. \& Co. Patent

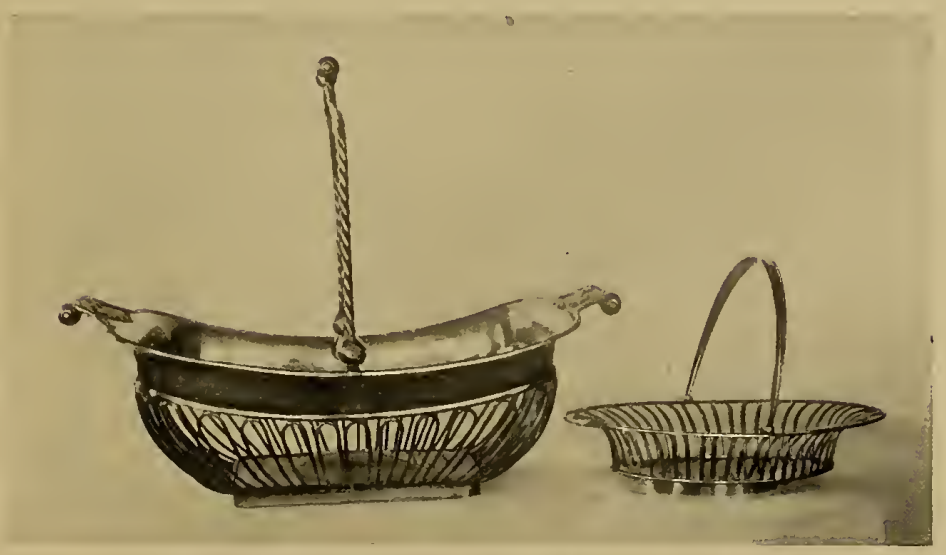

WIRE BASKET IVITII GILT DOMED BOTTOM (I800)

WIRE SWEET-BASKET WITH CHASED HANDLE (1790) 



\section{Plate XX}

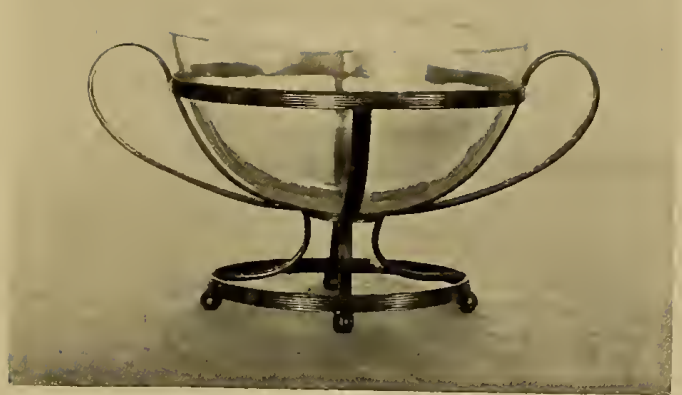

WIRE-WORK SIVEET-DISH HOLDER WITH GLASS DISH (I790)

PIPE-LIGHTER WITH BLUE GLASS LINER (I790)

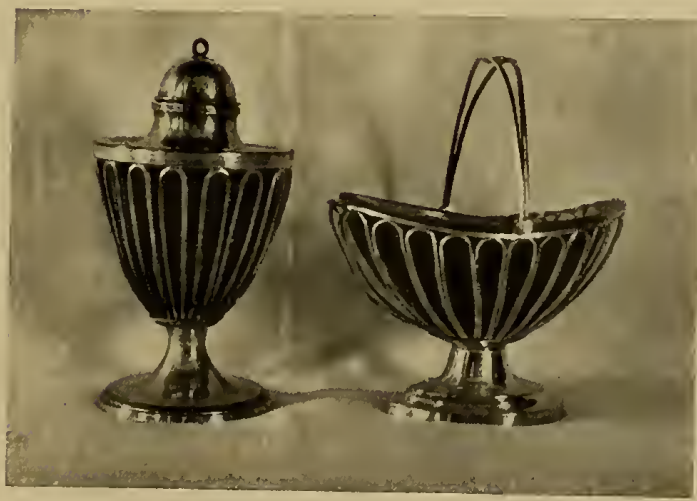

WIRE-IVORK

SUGAR-BASIN IVITH BLUE GLASS LINER (I790) 

The second epergne, of later date than the other, is perhaps more interesting to us on account of its history than for any special quality in the piece itself.

It marks one of the most memorable days in the whole history of our collecting. We seldom trouble ourselves over sales at old houses, for it frequently transpires that the valuable old furnishings have been previously disposed of and other goods substituted, or that arrangements have been made whereby the heirs to the estate "buy in" whatever is worth while. Moreover, if desirable antiques are actually offered at these big house sales, they are usually knocked down to one of the dealers in the "ring," and it is from the one who bids highest in the "knock-out" that they must be bought afterwards.

On this occasion we were told, by a friendly dealer, of a sale in North Wales where we should find something worth the journey. I shall never forget that house and its contents. It had belonged to an old lady who had lived in it during a lifetime of over ninety years. The house must have been originally furnished about 1780 , and some things had been added about twenty years later. From that time it had remained practically as we saw it, all carefully preserved in beautiful order. We had previously seen old houses that had been kept as show places, but here was one just as it had been lived in for nearly a century.

I will not try to describe the furniture. Our feelings were divided between a desire to possess some of the rare treasures, and regret that such a home should have to be dismantled.

Of the Sheffield Plate the thing that we wanted for our collection was the epergne, which we commissioned a dealer to buy for us. 
The glass dishes were missing, but we afterwards learned that the centre one had been sold separately. The buyer afterwards offered it to us, but we had already decided to have dishes made for the epergne to match a set of dessert plates that had just been made to our order. This, for collectors, was somewhat sacrilegious when we might have had the one original dish and the others cut to match, but as the new dishes are of the same shape as the original and quite as beautiful, we consoled ourselves. The epergne as it is makes a handsome centrepiece and completes an effective dessert service.

We were disappointed that our agent failed to obtain for us a dainty pair of sugar-tongs at this sale, but that circumstance proved fortunate in the end, for he introduced another dealer who said he had a similar pair in his establishment. This silversmith proved to be one of the most enthusiastically appreciative admirers of Sheffield Plate whom I have ever known "in the trade," and from him we have since purchased some of the finest specimens in our collection.

The heavy cut-glass basin with wire-work stand containing rings for a dozen spoons is an example of plated ware made in England to be sold in France. It is probable that a considerable part of the Sheffield Plate used in France was made in England, although as I have said before, a certain quantity was manufactured there. None of the Continental workmen, however, ever attained the degree of skill that was reached in England. The workmanship alone shows this piece to be of English make. 


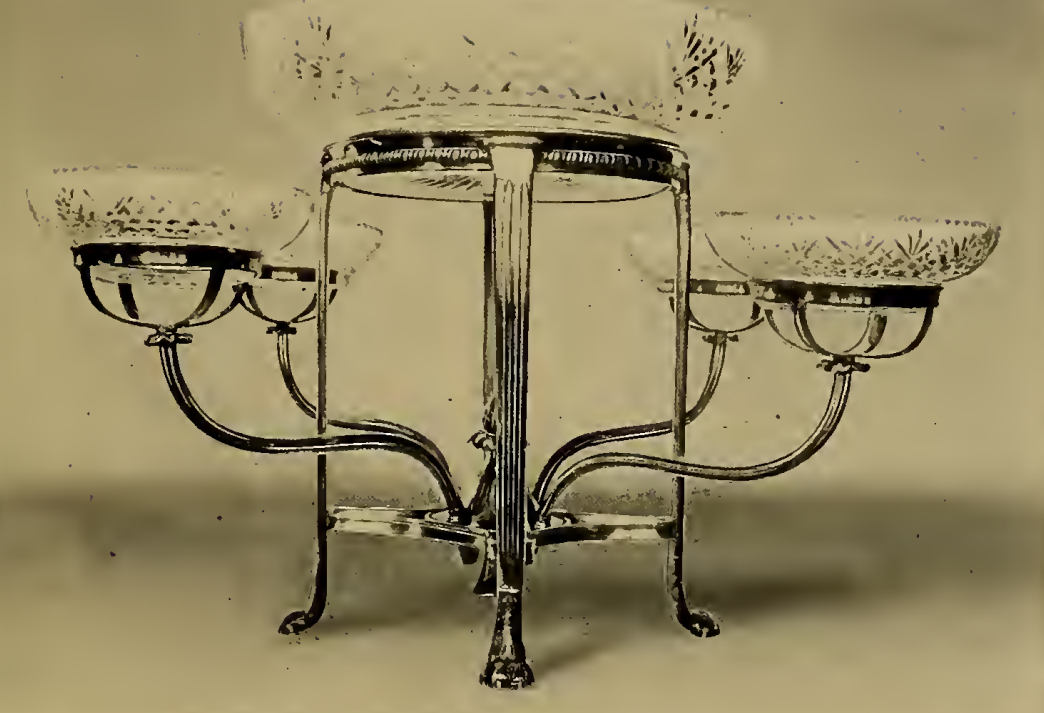

EPERGNE WITH CUT-GLASS DISHES (I810)

The dishes are not original 



\section{VII \\ SILVER BANDS AND SHIELDS FOR ENGRAVING}

A $\mathrm{S}$ it was the universal custom for family silver to be the plated ware had to bear the same devices, for Sheffield Plate was used extensively by the most distinguished, even the King, George III.

I have a catalogue of the sale by auction in 1848 of the contents of Stowe House, one of the seats of the Duke of Buckingham. This sale lasted thirty-seven days, and included the following in Sheffield-plated ware: twenty pairs of dish-covers, sixteen circular dishes, forty hot-water plates, four oval, four square, and three round heaters, four pairs ice-pails with stands, numerous vegetable dishes, souptureens, wine-waggons, venison dishes, decanter stands, sets of candlesticks, tea-urns, cruets, sauce-tureens, salt-cellars, etc., to the number of about four hundred pieces. This may give some idea of the quantities of Sheffield Plate supplied in that day to the nobility, and nearly every piece was adorned with a coat of arms or crest.

For the engraver to cut into the metal, as he must do, without exposing the copper was a very difficult task, even when the article was extra heavily plated. However it was 
frequently done, with the result that now after years of wear, one of ten sees the initials or monogram drawn in copper on a silver surface. A good example is the engraved turtle on the little tureen, where the only copper visible is the beautifully drawn turtle, the small portion of silver left by the engraver having worn off while the rest of the surface remains in perfect condition.

In order to provide for the engraving of a small device the whole article had to be more heavily plated than was otherwise necessary, and although the engravers adopted what became known as the "side-stroke" method, by which they cut only lightly into the surface, it became evident that a more satisfactory way must be found, for there was a demand for crests and monograms on the cheaper and less heavily plated articles, and the manufacturers were continually forced by competition to lighten the weight of the silver used in the rolled plate.

About 1790 bright engraving became fashionable as a mode of decoration, and occasionally trays and other articles where a large surface was to be engraved were made throughout of very heavy plate for the purpose, but where only a small portion was to be engraved, a band or shield of silver was sometimes soldered on in the same way as the thread borders and other mounts. The teapots illustrated opposite page 36 furnish good examples where engraved silver bands are used solely for decoration.

I once saw a coffee-pot with an engraved silver band round its middle and below this a round silver shield with a handsome monogram. The rest of the coffee-pot was polished copper and the effect was not unpleasing. It had been a Sheffield Plate article like the teapots, but made of rather 
Plate XXII

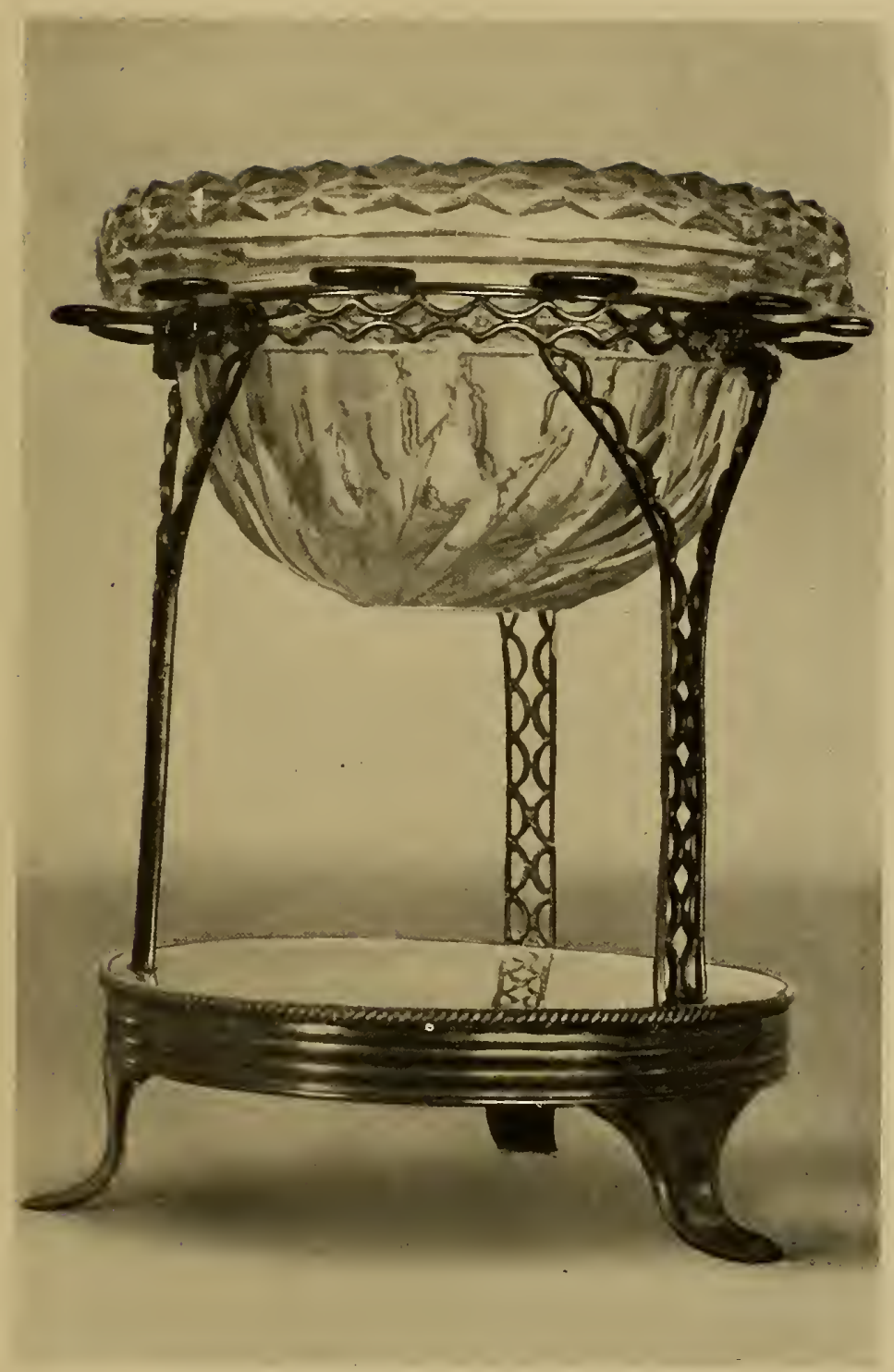

CUT-GLASS SUGAR-BASIN IN WIRE-WORK STAND

WITH RINGS TO HOLD TWELVE SPOONS (1810) 



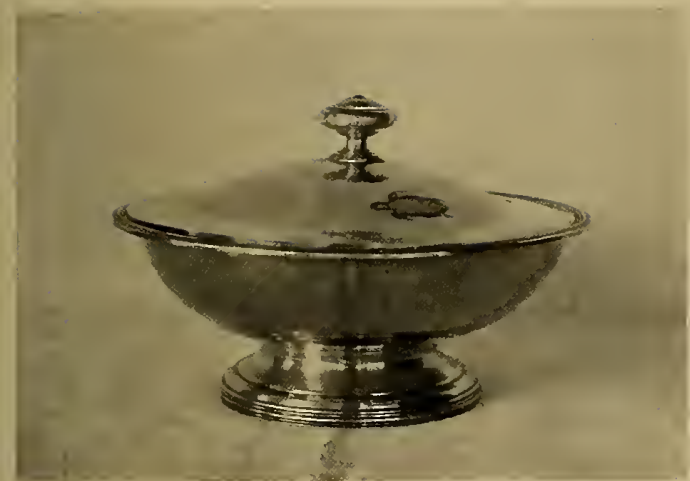

SMALL TUREEN FOR TURTLE SOUP (I790)

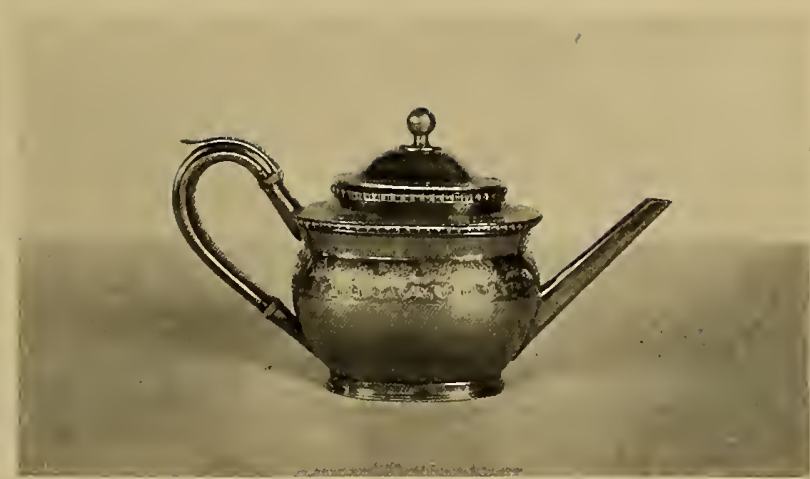

HALF-PINT TEAPOT WITH SILVER GADROON EDGES AND ENGRAVED SILVER BAND (I8co)

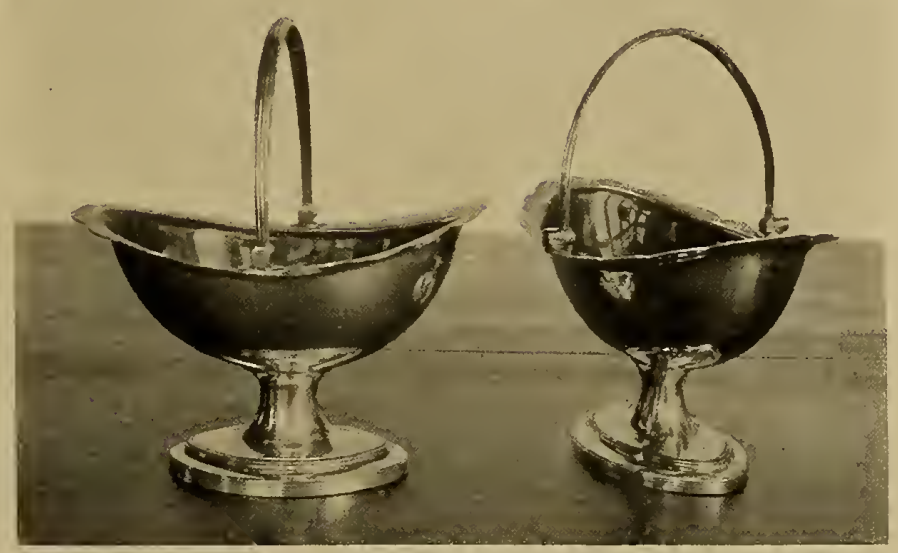

PAIR OF BASKETS MOUNTED WITH SCALLOPED BANDS OF ENGRAVED SILVER (I795) 

lightly-plated metal. With constant use and cleaning every vestige of its silver coating was gone except the band and shield. Many of the prettiest tea- and coffee-pots have these beautifully engraved bands.

The tiny teapot must have belonged to a set, for $\mathrm{Mr}$. Bradbury ${ }^{1}$ says that single teapots were never made with all metal handles. I should be very glad to find the sugarbasin and cream-jug belonging to this one. It is the smallest Sheffield Plate teapot I have ever seen.

Engraved bands were occasionally used as mounts for finishing the edges. Those on the rather distinctive pair of baskets are raised from the flat surface of the turned-back margins and the scalloped edges are slightly turned under to form a finish. The effect is decorative and unusual. I cannot guess why one of these baskets is gilt and the other silver-plated on the inside. Otherwise they are alike and they match one of the cream-jugs in the group shown in Plate LIII. This cream-jug was undoubtedly the work of the same maker.

The shield on the claret-jug (Plate XXIV) is an elaborate example of an applied coat of arms. Such a shield consists of a flat piece of silver cut to the shape of the engraved design. The edges are turned back at right angles for about one sixteenth of an inch so that the shield forms a raised mount. It is fixed to the surface of the article with soft solder.

While shields soldered on the outside were very satisfactory for certain pieces, the fact that they were raised above the surface made them unsuitable for others. If the buyer of a flat tray, for instance, wished to have his monogram engraved in the centre, he naturally demanded that the

1 Frederick Bradbury, History of Old Sheffield Plate. 
tray when finished should look like a silver one where the engraver had cut into the metal as deeply as he chose. Here was another problem to tax the ingenuity of the Sheffield artisan, but he was never found wanting.

The pair of oval trays illustrates a method by which a piece of rolled plate, much more heavily silver-plated, was "let in" in such a way as to leave the surface quite flat. A piece exactly the size and shape of the shield to be let in was cut out of the body of the tray and the shield carefully hard-soldered into its place. The article was then annealed and hammered until the joining became practically invisible. When the engraving was done, a tiny ornamental border was chased around the edges to conceal any traces that might remain of the seam where the shield was let in. It is plainly visible on the back of the tray, which is shown reversed in the photograph.

These let-in shields were only applied to well made articles, and in the old catalogues prices were quoted with or without a soldered-in shield, the extra charge varying from five to twenty-five shillings.

From the beginning of the industry the Sheffield platers had made use in emergencies of a process already well known as French plating. This was done in the following manner when by any accident the copper became uncovered in a piece that was partly finished. Sometimes an article was exposed to intense heat and became blistered. While it was still hot the workman punctured the blister and tried to replace the loosened silver with his burnisher; failing this he removed the loose bit and thoroughly cleaned the copper surface. Then he applied a thin leaf of pure silver which had been heated in a flame, and rubbed it with his burnisher 


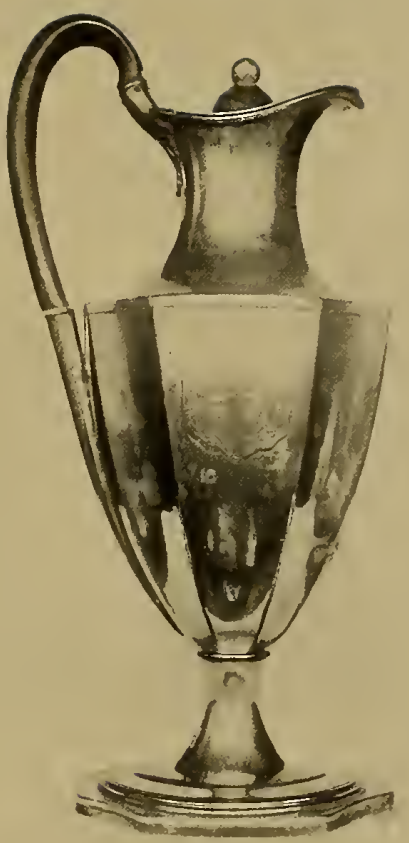

CLARET-JUG WITH SOLDERED-ON SILVER SHIELD (I795)

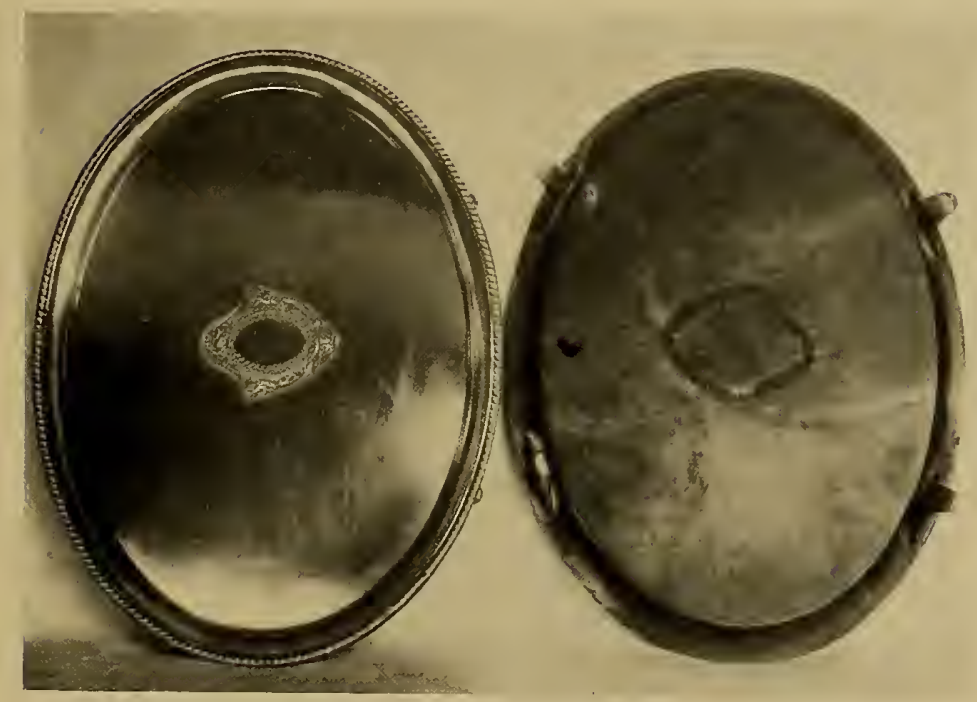

PAIR OF OVAL TRAYS WITH SOLDERED-IN SHIELDS (I789) The one at the right is reversed to show appearance of shield at the bacl: 

till it adhered. Other layers were added in the same way till the surface was evenly plated as before. The little square tea-caddy (Plate XXV) shows such patches all over its four sides. The blistering must have occurred when the piece was nearly finished, or it would not have been worth while to repair it. When the surface is clean these patches cannot be seen, but since the alloyed silver used for the fused plate tarnishes more readily than the pure metal in the patches, they are quite conspicuous when the article has been long exposed to the air without cleaning.

The process of French plating was also applied to the insides of hollow ware, especially small portions like spouts and lids, in the early days when the rolled plate was silvered only on the one side.

No doubt it was French plating that suggested the most ingenious of all methods of dealing with the portion intended for monograms or initials, the "rubbed-in" silver shield, which like the patches is quite invisible when the article is perfectly clean. The little oblong snuffer-tray and the large dish-cover have shields of this description, which contrary to the popular impression are not a sign of superior quality, but show that the article was made of more thinly plated metal than would otherwise be used. Be it remembered that the sole object in adding these shields was to cheapen the production of the finished article. They are usually found on pieces of only medium quality plate, though they are always associated with good workmanship. The method was as follows, and it will readily be seen that the process required considerable skill. The shield was usually applied before the article was made up. It consisted of a flat piece of silver which was slightly heated and the edges 
bevelled off with a hammer till they were as thin as possible. The shield and the smooth surface to which it was to be applied were then thoroughly cleaned and rubbed with fine brick-dust, then the shield was fastened in place with a wire and the article heated. When a certain degree of heat was reached, the shield began to adhere to the surface and could then be burnished down in the same manner as the leaf silver used in French plating. After the whole was carefully annealed and hammered, the shield had become a part of the plated surface. Although the description would make it appear simple, the actual performance was a very difficult one. However, some of the old workmen attained great proficiency, and rubbed-in shields were extensively used from about I8Io. 



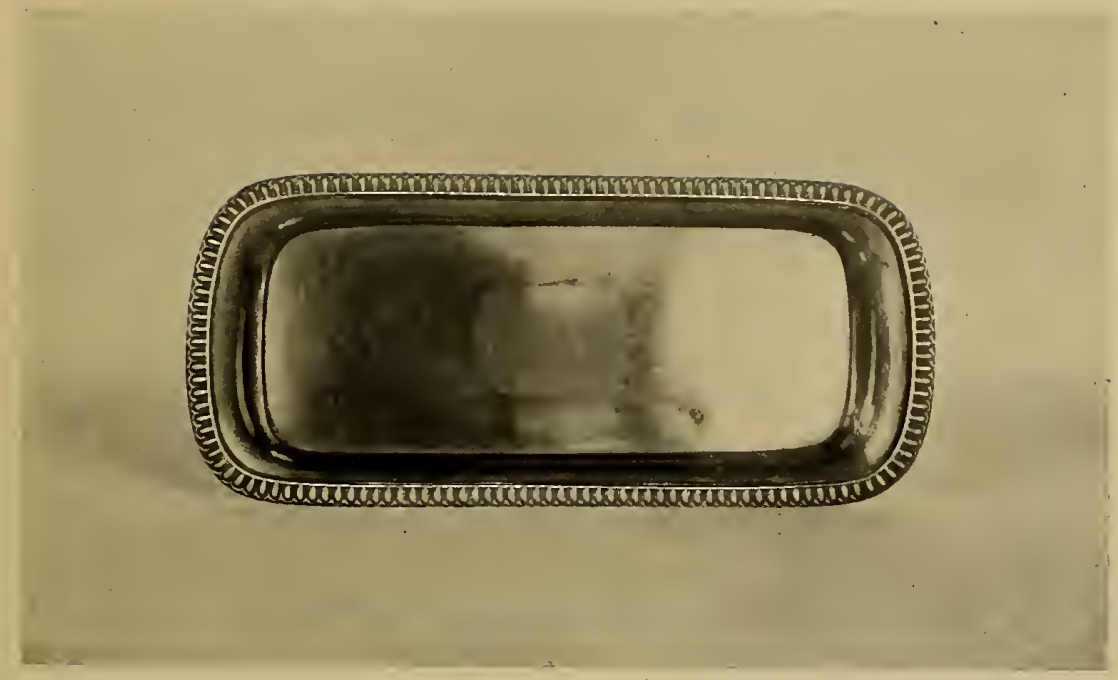

SNUFFER-TRAY, TARNISHED TO SHOW RUEEED-IN SIIIELD (I800)

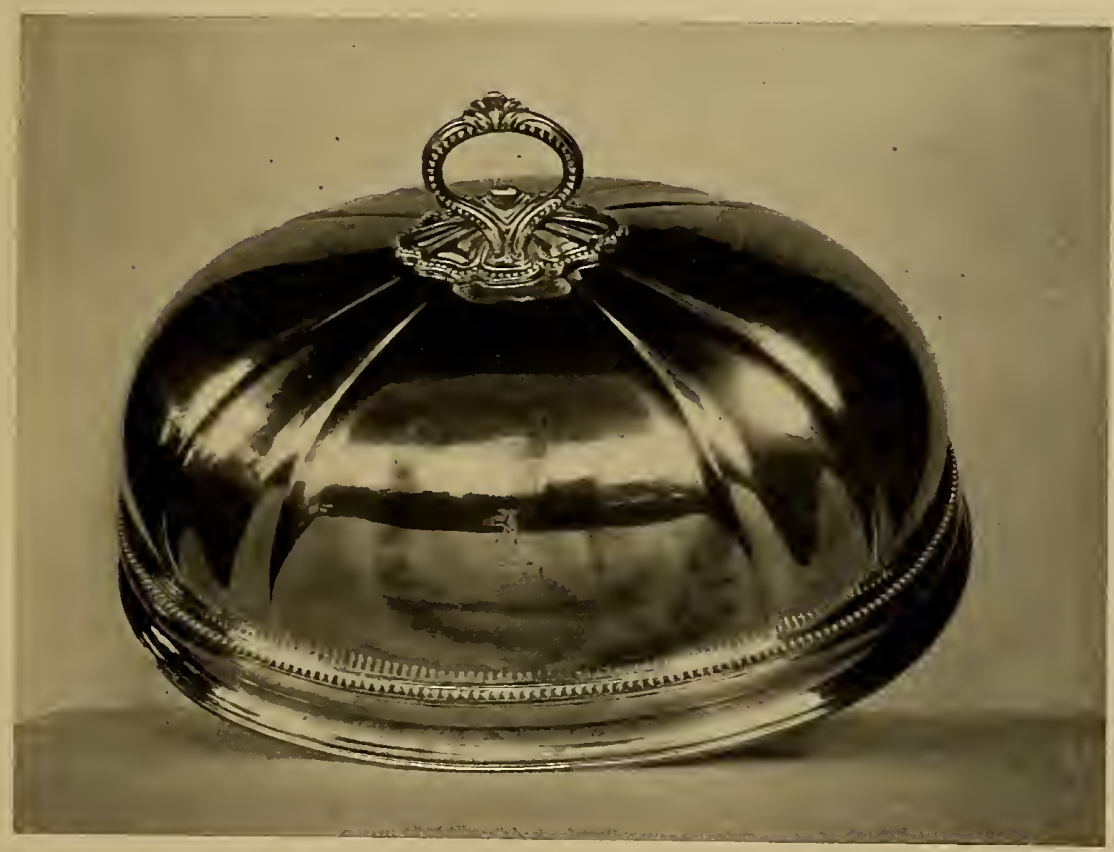

DISH-COVER, ONE OF THE SET SHOWN IN PLATE XLVIII. TARNISHED TO SHOW RUBBED-IN SHIELD (I830) 



\section{VIII}

\section{CANDLESTICKS}

$\neg \mathrm{HE}$ subject of candlesticks is of such universal interest

1 that it is difficult to decide where to begin, and perhaps more so to know when to stop. It would be pleasant to trace the history of these suggestive objects from very early times, and to follow the story of their evolution in varying materials, for the candlestick in some form is as old as civilization.

When and how the first primitive candles were evolved I have never heard, but we do know that until comparatively recent times a candle has been an expensive luxury, and we may infer that it was no less so in ancient times. It was fitting that the container for such a precious light-giver should be a worthy receptacle, and like other costly articles of elaborate workmanship, the candlestick of the ancients was doubtless used for purely ecclesiastical purposes.

We may well believe that the seven-branched candelabrum in the temple of Jerusalem represented the climax of the maker's art, for we know that the metal workers of those days possessed most wonderful skill, and they were not hampered for want of either time or material. When we think of the colossal statues and pillars of solid gold wrought 
in ancient times, we may well wonder how it ever became necessary to make anything with a gilded or silvered outside. However, while precious metals were so lavishly used for works of art which represented the patriotism or the religion of a whole community, it does not appear that candlesticks made of precious metals were often the property of individuals. In modern times, however, the metal candlestick of more or less ornamental pattern acquired an almost unique place among household furnishings, until it came about that even the dwellers in the humblest cottage aspired to at least this outward symbol of luxury. In some form or other it still has a place on almost every living-room mantelpiece, and the old-fashioned bedroom candlestick is still an article of daily use in many homes, pretentious or otherwise. What wonder that if only for sentiment's sake we still cling to these pleasant reminders of the simple life of our forefathers; and what more attractive souvenir of the past than a fine set of eighteenth-century candlesticks? If they have actually come down from a past generation, so much the better; but if not, there is certainly much pleasure to be derived from the possession of a few good copies.

As to material, it seems to me that a modern candlestick in plated ware has no excuse for being; for silver is now comparatively cheap, and fairly durable articles of solid silver are made at a moderate price, to say nothing of the tremendous quantities now produced whose silver substance is of paper thinness. Very different conditions existed a century and a half ago when Sheffield Plate came into its great popularity. In those days not only was silver dear, but the method employed for making silver candlesticks was to cast them in moulds and then finish by hand. This required 


\section{Plate XXVII}

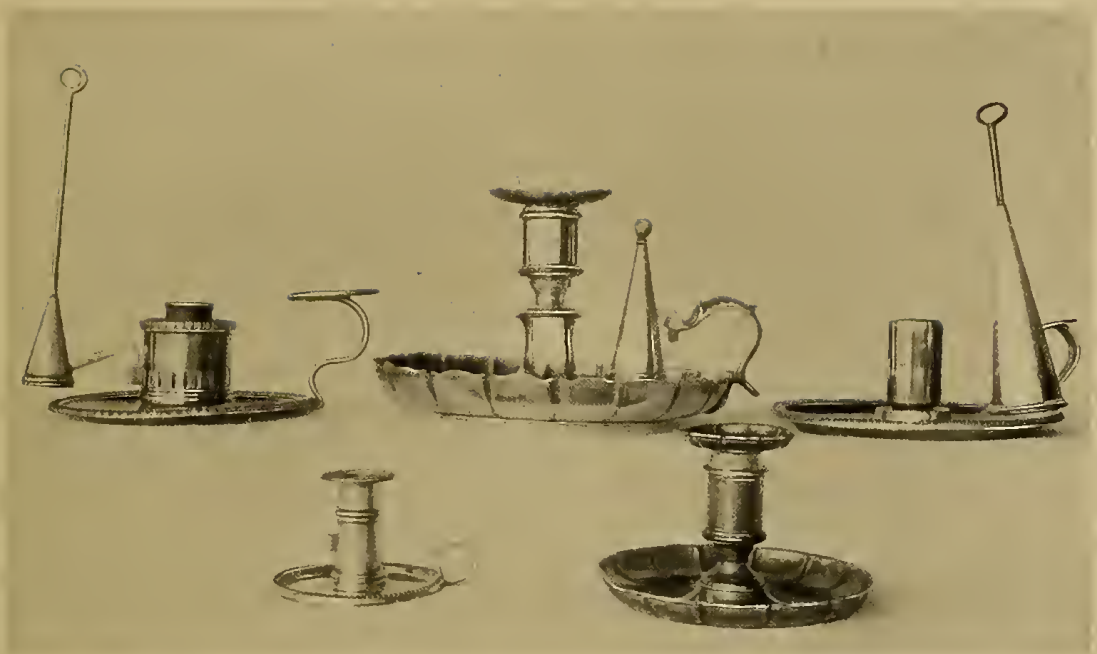

CHAMBER CANDLESTICK WITH HOLDER FOR GLASS GLOBE (I800)

DITTO, WITH SPACE UNDER CANDLE TO HOLD SNUFFERS (I795)

This candlestick and the taper-stick below it have silver edges hard-soldered on

They are by Matthew Boulton. (Marked. See page 68)

CHAMBER CANDLESTICK WITH GADROON MOUNT (I8IO)

BEAD-MOUNT TAPER-STICK II INCH HIGH (I785)

DITTO TO MATCH CANDLESTICK (I795)

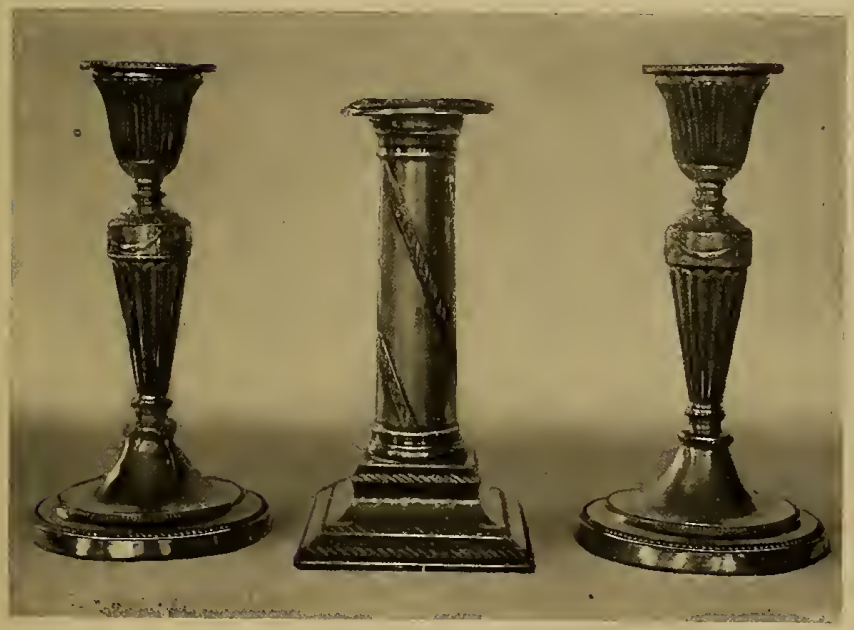

PAIR OF FINELY FLUTED ROUND CANDLESTICKS (1785) SINGLE SEVEN-INCH CANDI.ESTICK (I780)

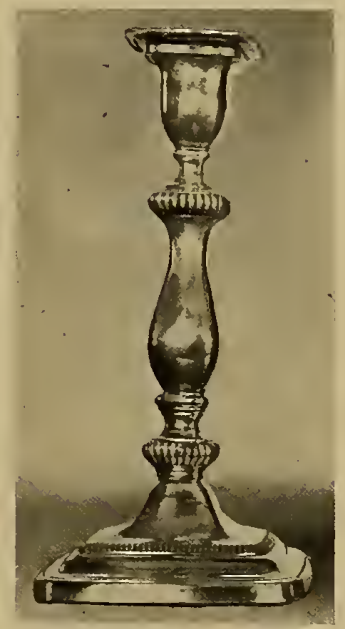

GADROON MOUNT OBLONG CANDLESTICK (I808)

Ry A. Goodman \& Cu.

(Marked. See Plate LI) 

a large quantity of the precious metal and rendered the finished article very expensive, and any method by which a good and durable imitation could be produced was bound to be a commercial success.

To copy the old silver candlesticks in plated ware presented a difficult problem, and it is only natural that the first attempts were somewhat crude. Let us imagine one of these early artisans with his sheet of rolled plate before him. Suppose he wished to make a stick like the one illustrated in the following Plate, which is the most simply constructed one in our collection. The model from which he copied had been cast in two moulds, the base and the halves of the upright portion. Obviously the moulds would not help him to fashion his rolled plate. He must cut out an oval piece for the base and gradually raise it to the right shape by means of hammers and swages, then from two strips he might form the halves of the pillar portion in the same way; but the task of shaping the parts and making them fit symmetrically would be extremely difficult, and he would find that he had lost as much in time as he had gained in material, so he must find some mechanical device for gaining accuracy and saving time. Now steel dies had already been used for stamping spoon-bowls, teapot spouts, etc., and the same method naturally suggested itself for the candlesticks. For this one he would need only two dies, shaped like the moulds for casting the silver one. These steel dies required most skilful cutting by a trained die-sinker, but many candlesticks could be made from the same set of dies, and the new method proved such a success that silver ones were soon made in this way. Thus the method employed for the imitation was imitated for producing the original, and the process of making silver 
candlesticks by casting was abandoned almost immediately.

It was due to this innovation in the method of making silver candlesticks that Sheffield began the manufacture of solid silverware as well as plated goods on a large scale. Their silver and plated candlesticks became extremely popular and have remained so, for the manufacture of silver candlesticks from the old dies still goes on in Sheffield.

The hollow stick is made rigid by an iron rod through the centre, and the whole is filled with a resinous mixture, which is poured in hot and becomes very hard when cold. The early Sheffield-plated candlesticks had bottoms of rolled plate, but these were soon superseded by wooden ones which are usually covered with green baize.

Next in simplicity of plan to the little oval stick are the square ones with round columns. The bases and capitals were four stampings soldered together, and the column was made from a flat sheet with the flutings and other ornamentations struck in a die before it was joined together to form a tube. Columns in square section were struck in four pieces; the urn-shaped capitals were sometimes in two pieces and sometimes in four. Colletts and necks were at first hand-wrought, but afterwards die-struck. Nozzles were added about the middle of the eighteenth century.

Until the introduction of silver stampings for mounts, etc., plated candlesticks were made entirely from the rolled plate, but as the styles grew more ornate and elaborate, silver stampings (lead filled) were added to such an extent that finally there was very little of the plated portion left.

To the simple table candlestick modelled after the classic pillar new devices were frequently added, and there were all sorts of patent contrivances. There were a number of 


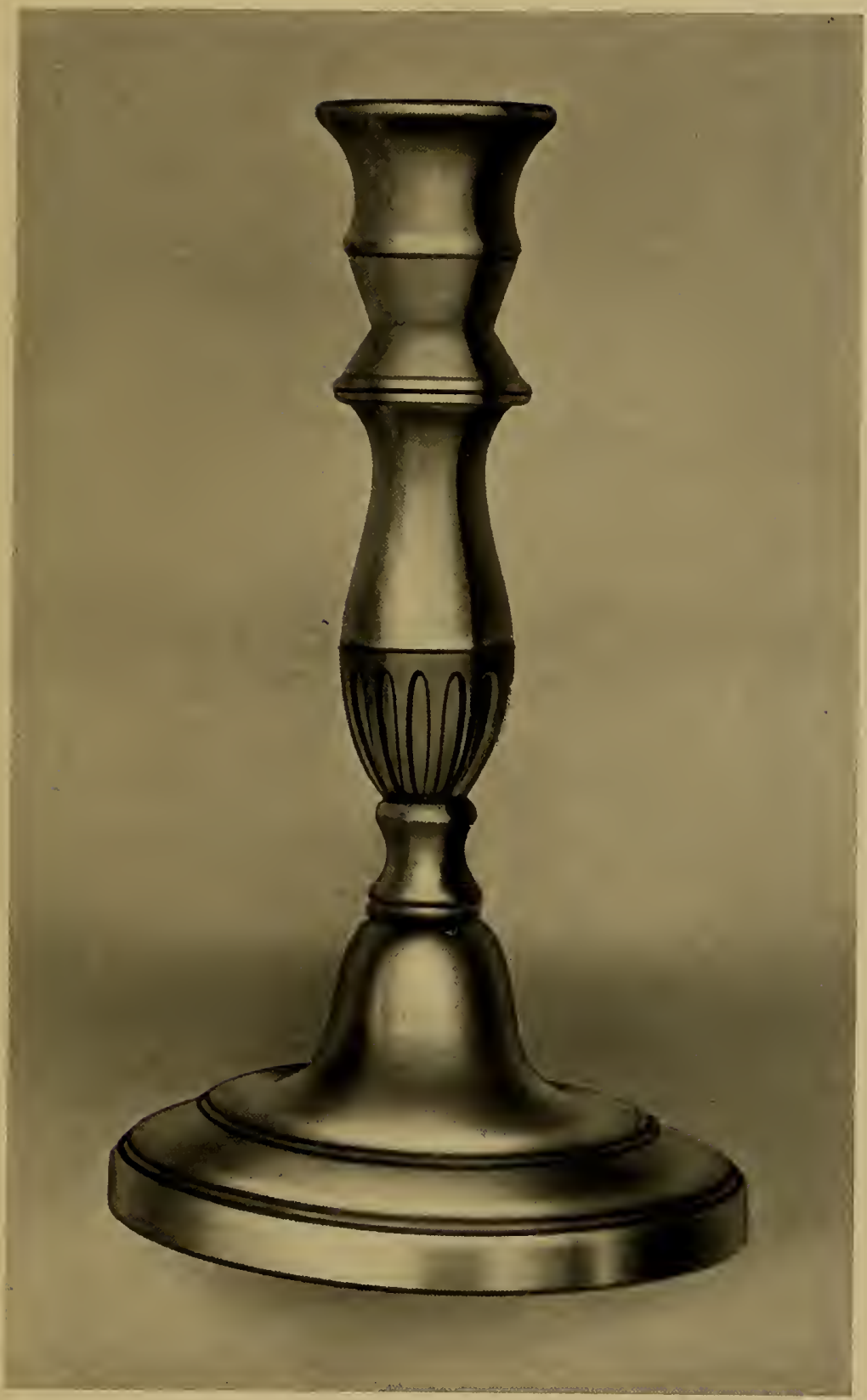

OVAL CANDLESTICK STRUCK IN THREE SECTIONS FROM TWO DIES (I790) 

patents for telescope sticks which could be made higher or lower at will. This would seem to us rather a useless device, but when we consider that our ancestors depended upon candlelight for seeing, it becomes apparent that the position of the candle was an important matter. The telescope candlesticks seem to have supplied a want, for they became very popular and large quantities were made about $\mathrm{I} 800$.

There were also the branch candlesticks of which these spirally fluted ones shown in Plate XXIX are typical. They can be used as a pair of three-light candelabra, or as a fivelight candelabrum and a tall table stick. There were sometimes devices by which the branches could be folded back or extended, and during the later period there were many interchangeable candelabra and epergnes. They were often too heavy and elaborate to be beautiful.

Branches were often made and sold separately to be used with sticks already in use. It is partly for this reason that one often sees candlesticks with branches that do not match, though of course they have sometimes become mixed in other ways.

It can readily be seen what a number of dies would be necessary for the production of a candelabrum like those illustrated, and the cost of a set of candlestick dies ranged from $£_{20}$ to $£_{50}$. It was therefore necessary that a great many articles should be made from the same set in order to pay for the die-cutting; but the parts were sometimes combined in different ways, so that candlesticks varying somewhat in size and shape could be made from the same dies.

To the great popularity of candlesticks in the days of Sheffield plating we owe the fact that it is now fairly easy for the collector to find beautiful specimens in good condi- 
tion, though out of the vast number that were manufactured a comparatively small number have survived.

If content to take them singly, one may even now get together a really interesting collection of Sheffield Plate candlesticks for a moderate outlay. For any one wishing to collect old plated ware in a comparatively small way it would be difficult to choose anything more decorative and fascinating than a well-selected group of these survivals from old-time customs. A dozen typical specimens might form a fairly complete nucleus for a collection which could be extended indefinitely.

It would be interesting to supplement such a collection with a few taper-winders, bougie-boxes, and snuffers, all of which helped to complete the household lighting arrangements before the days of gas and electricity. 
Plate XXix

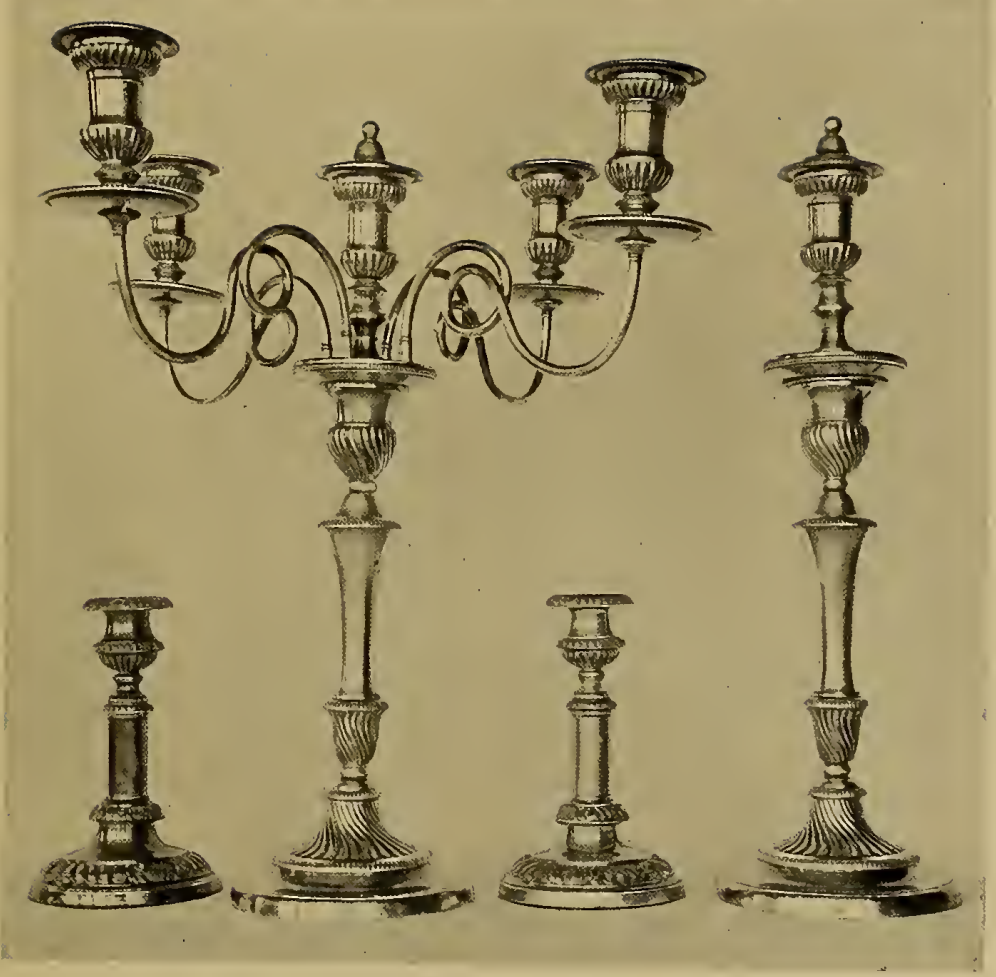

FLUTED CANDELABRUM FOR FIVE CANDLES WITH TALL TABLE CANDLESTICK TO MATCH (I800)

TELESCOPE CANDLESTICKS SHOWN ON FOLLOWING PAGE. (Closed)

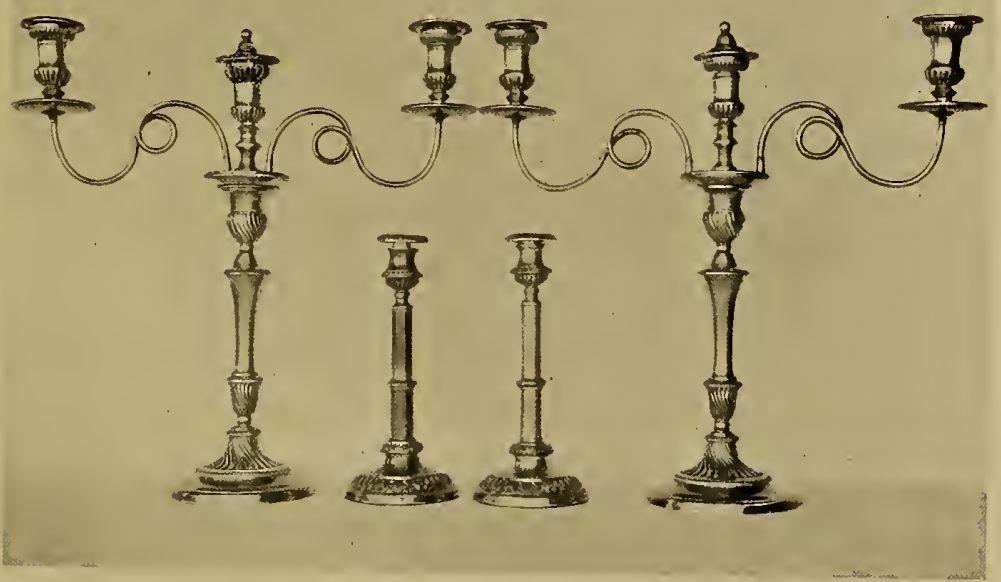

SAME AS ABOVE ARRANGED AS A PAIR OF THREE-LIGHT CANDELABRA TELESCOPE CANDLESTICKS. (Open) 

Plate XXX

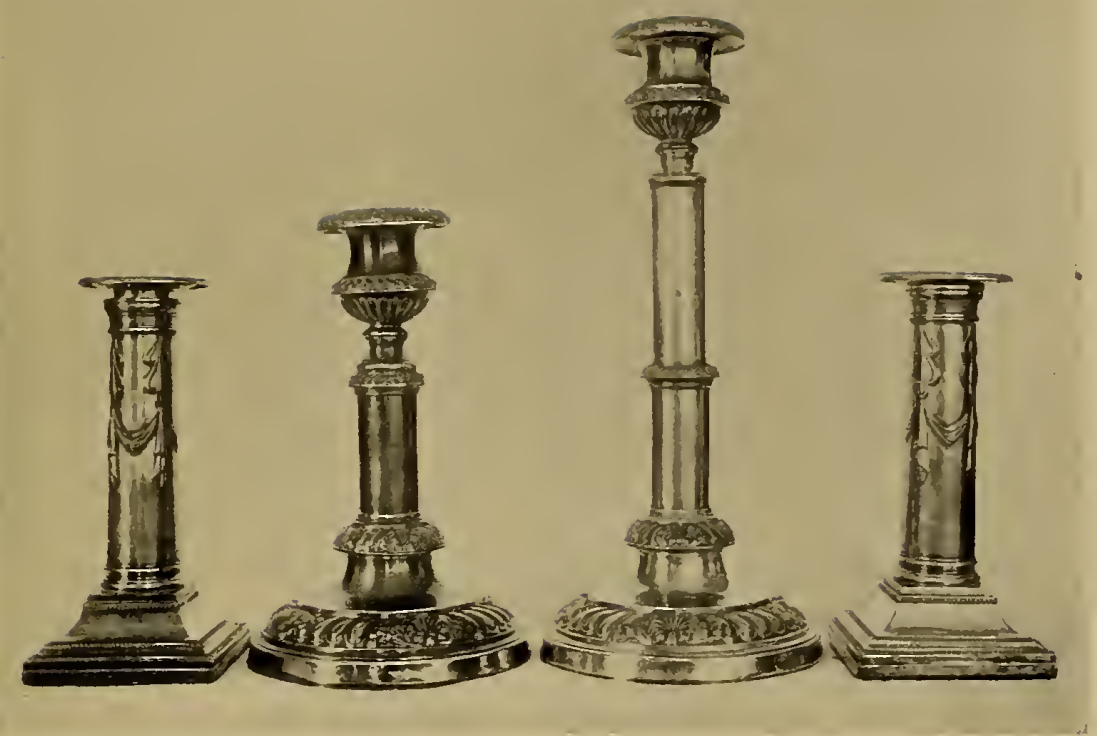

PAIR OF ADAM CANDLESTICKS ( 1780 )

PAIR OF FLUTED TELESCOPE CANDLESTICKS (1800)

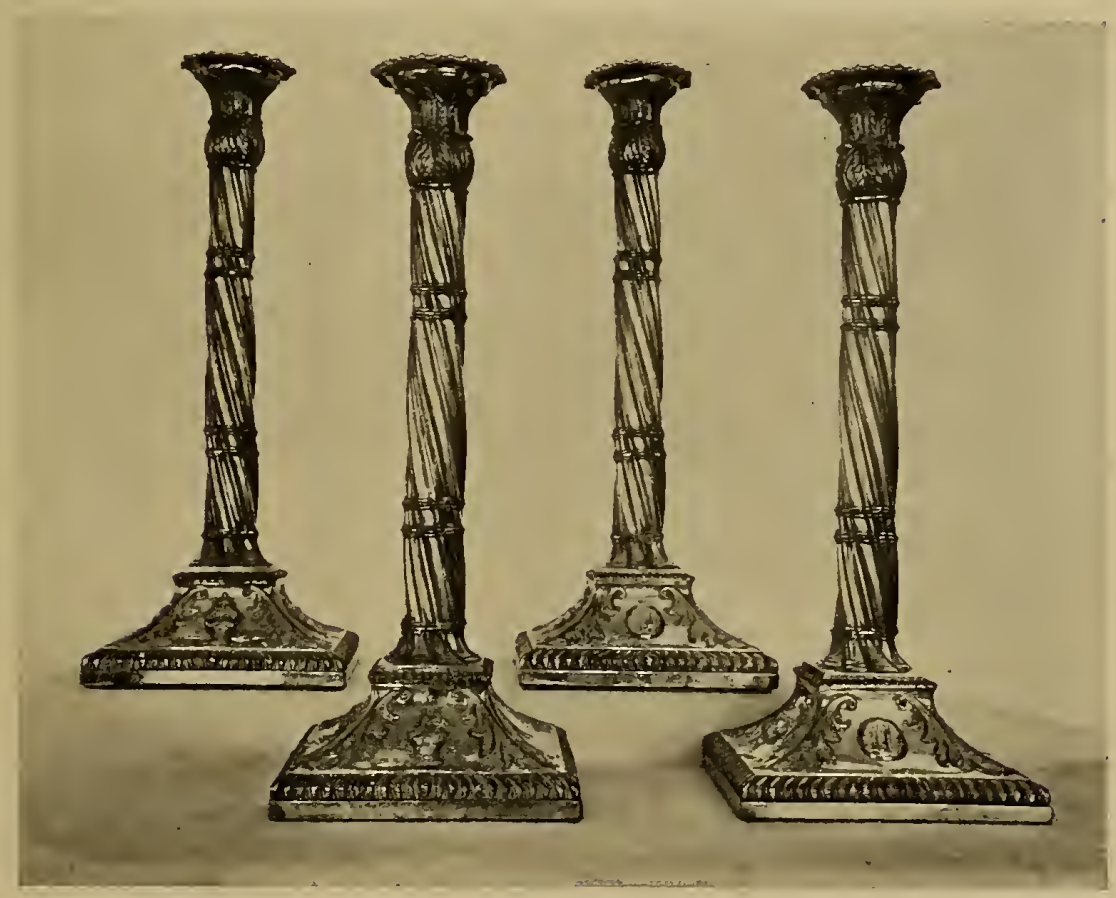

SET OF FOUR TALL TIVISTED-COLUMN CANDLESTICKS (I773)

By Thomas Law

A silver candlestick of identical pattern, hall-marked 1773 , may be seen at New College, Oxford 



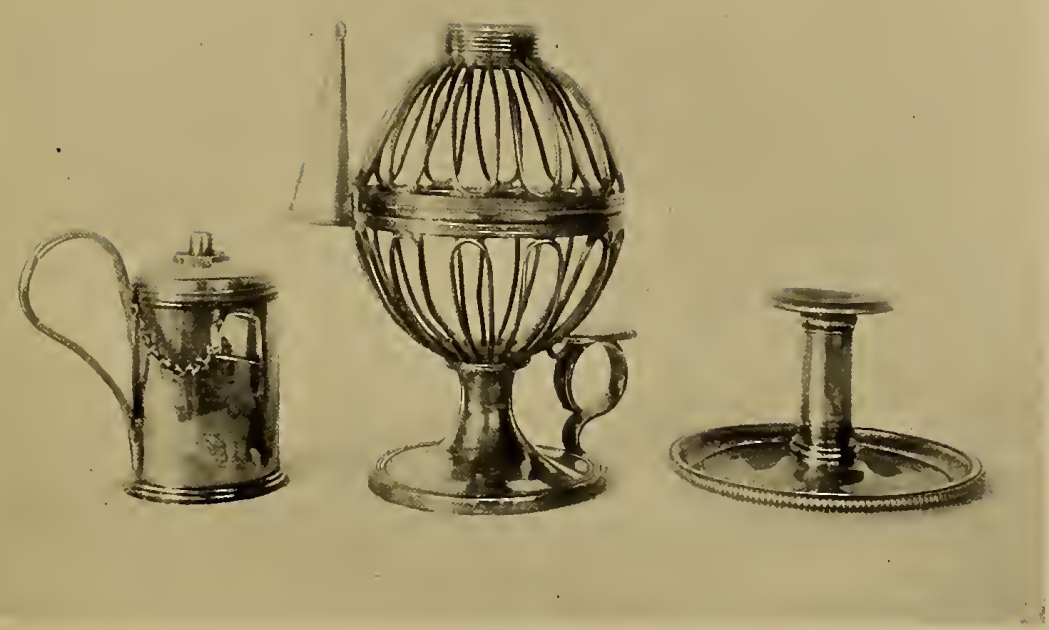

BOUGIE BOX (I790)

WIRE-WORK WAX-WINDER (I790)

ROUND TAPER-STICK WITH GADROON MOUNT (I800)

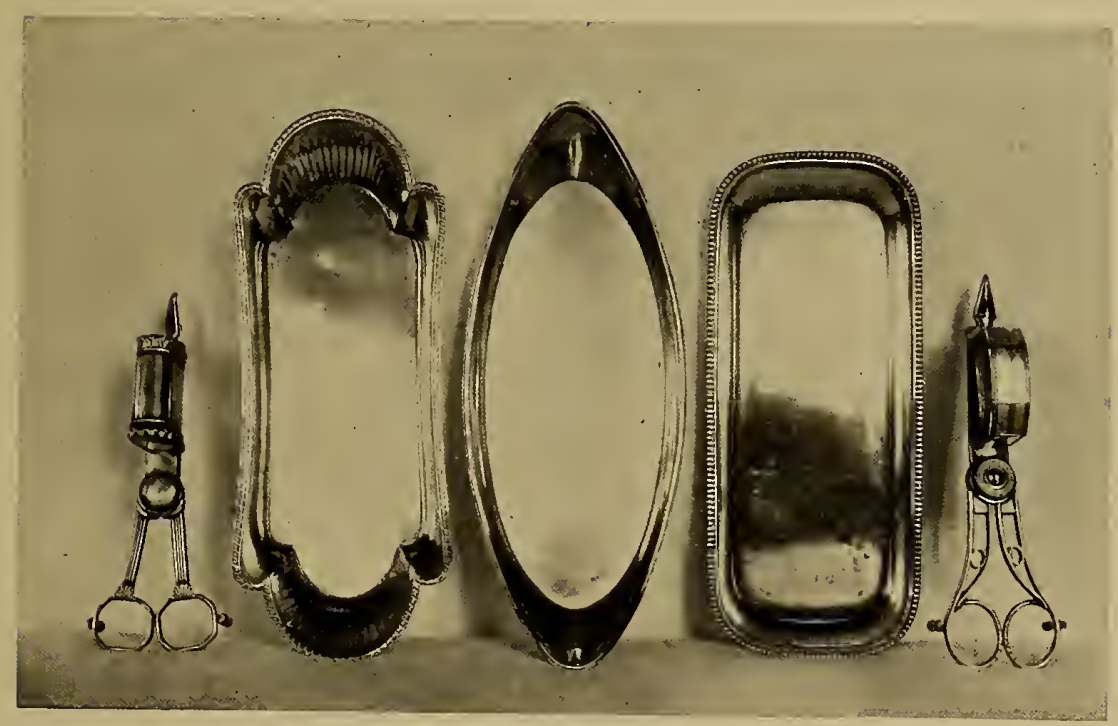

SNUFFERS $\Lambda$ ND SNUFFER-TRAYS (1790-I800) 

Plate XXXII

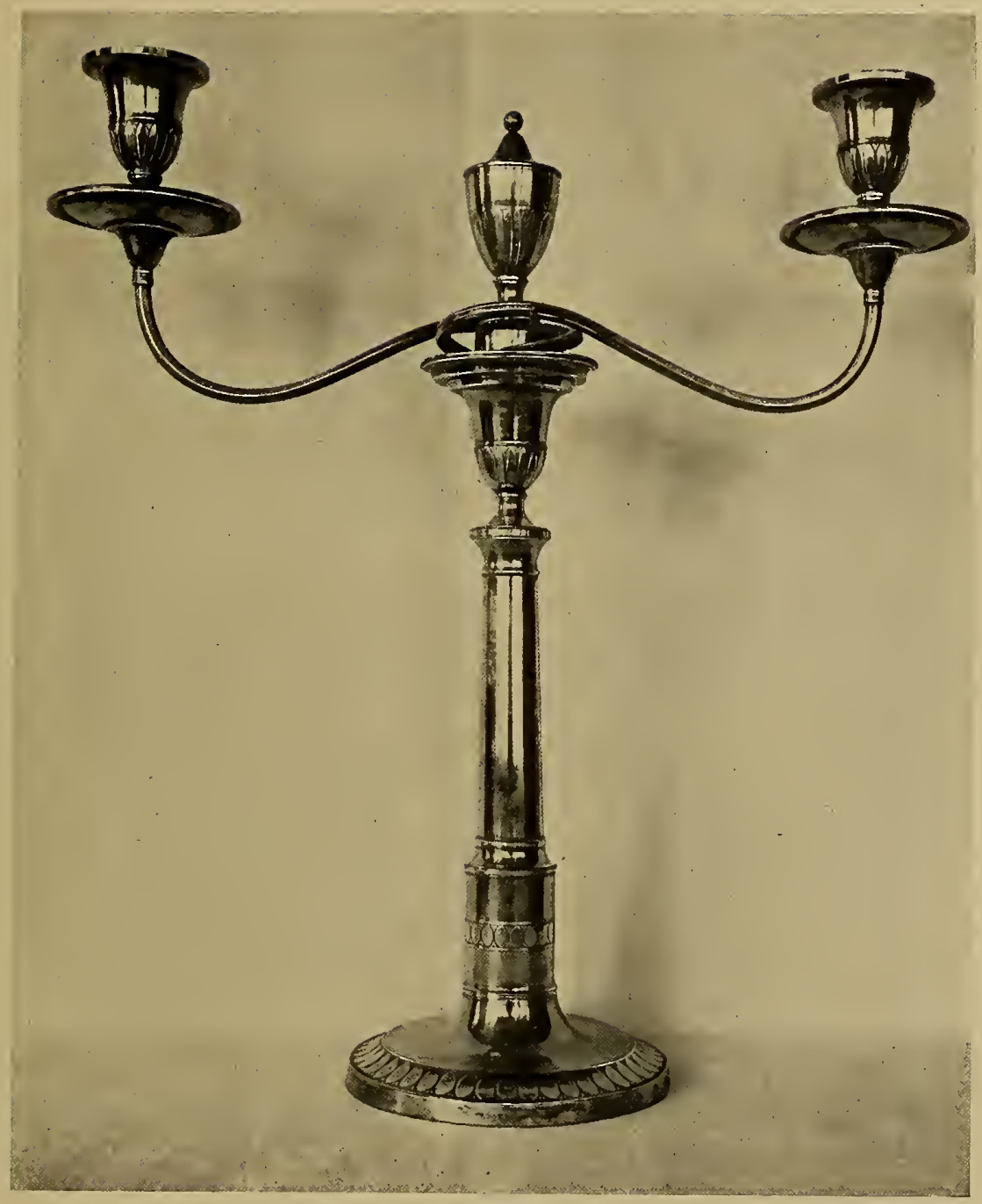

FLAT-FLUTED CANDELABRUM (I792) 



\section{IX}

\section{A VISIT TO SHEFFIELD}

A $\mathrm{S}$ the plating industry grew with marvellous rapidity other English towns, notably Birmingham and London, and also to some extent on the Continent; but the historic interest pertaining to it will always remain centred in Sheffield, where the process had been invented and where by far the greater portion of the goods was produced.

It is not unnatural that there is little Sheffield Plate for sale nowadays in its original home, for the residents of the town have learned to prize whatever pieces they may possess, and any specimens that find their way into the shops have usually been purchased elsewhere. Nevertheless we have been lucky enough to find a number of interesting specimens for sale there, and the fact that we purchased them in Sheffield gives them a little added interest.

A Sheffield dealer once told me that during the preceding ten or fifteen years he had sold hundreds of the old saltcellars to American tourists. As he had found them readily salable, both on account of their attractiveness and portability, he had made a special effort to find them whenever he visited the neighboring country. 
On our first visit to Sheffield my husband and I were shown over several factories where the old plate had been made, and where the descendants of the original owners now manufacture large quantities of silver and modern plated ware.

We had with us the large claret-jug which is a marked piece by one of these firms, and it proved to be the occasion of several interesting discoveries. First, it had been made in 1850 and sold to the original buyer for five pounds (exactly what we had paid for it). Now electro-plating had been introduced in 1840 , and was so much more easily and cheaply accomplished that in the end it quite supplanted the old method, but we were told that since many of the firms had quantities of the rolled plate on hand, they went on using it for some years in goods of better quality. The body of the claret-jug is of extra heavy plate on copper, and the floral design is engraved, not chased, which is very unusual in Sheffield Plate. The handle and lid are of silver rolled on white metal (commonly known as " nickel silver" or "German silver"). As this alloy was much less conspicuous when the article became worn and being harder could better resist wear, it gradually superseded copper as a foundation metal for rolled plate after 1830. However, the designs had now become heavier and less graceful, and one seldom finds specimens made during this period which are of much interest to the collector. This jug is somewhat exceptional, being far more pleasing than most of the late pieces, whose ugliness is partially redeemed by their beautiful quality.

On leaving the office to go over the factory, we noticed that the door was held open by something on the floor resembling a brick. It was one of the old ingots that had never 
Plate XXXIII

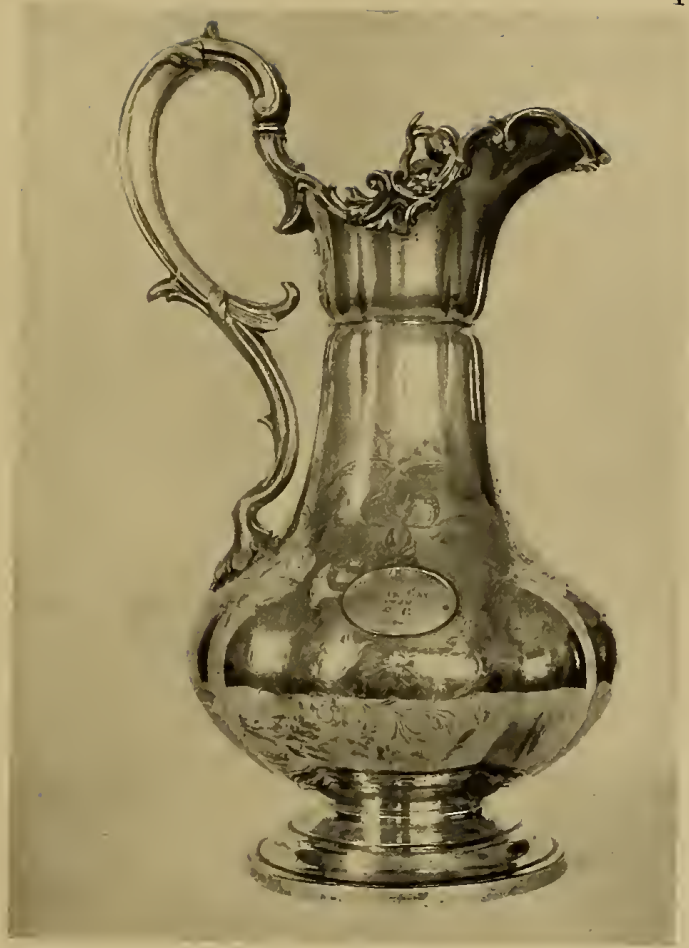

CLARET-JUG (I850)

By Smith, Sissons \& Co.

(Marked. See page 67)

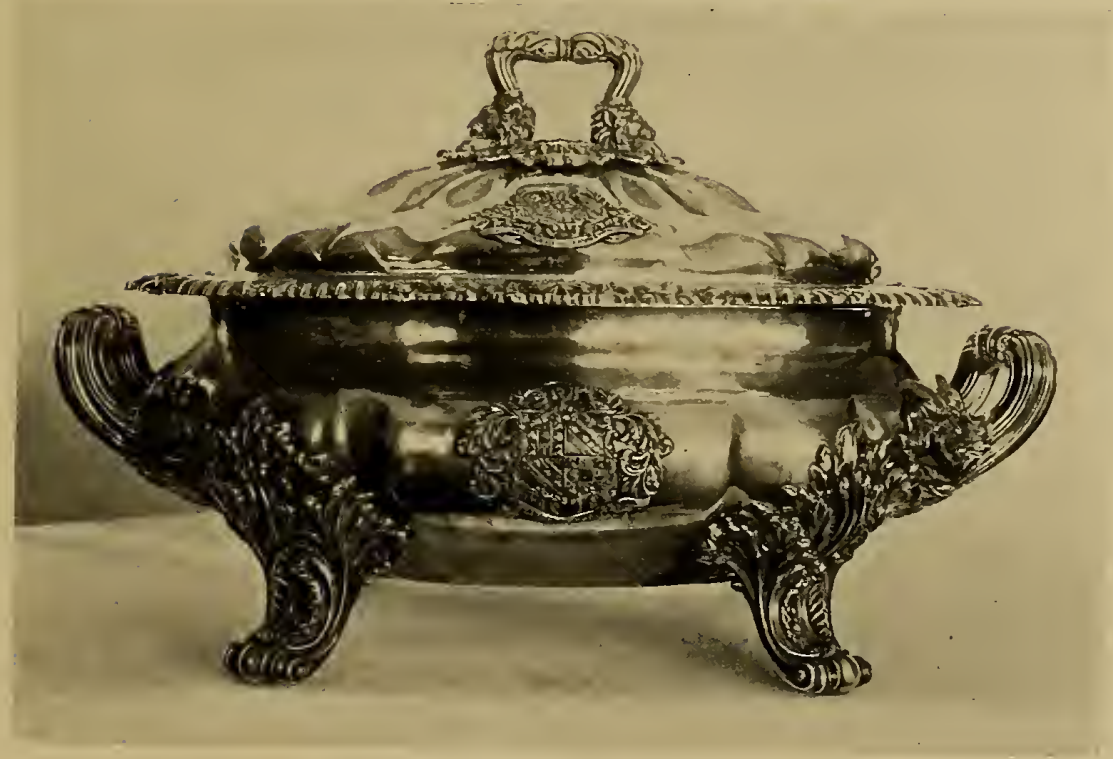

SOUP-TUREEN (1830)

By T.\& J. Creswick

(Marked. See page 67) 

been rolled, and is now preserved as a curiosity. The copper bar is about two inches thick and the layer of silver on the top about one-eighth of an inch. The whole ingot would have made a sheet about as thick as a silver dinner plate.

Another marked piece which proved of interest was the soup-tureen of which we had a photograph. The owner of the works said he could show us the very dies from which the handles and mounts had been struck, for although the firm that made them had gone out of existence years ago, many of their dies had been preserved and were now in the cellar below where we were standing.

Going down the winding stone stairs into the underground portions of these old factories is like descending into the dungeon of some ancient castle. Many of the rooms are without daylight; both floors and walls are of stone. The former are necessarily very solid to help form sufficient foundation for the heavy machinery. In one of these dark rooms we saw bundles of heavy dies arranged on shelves and floor. There were long narrow ones for the stamping of strips to form the delicate thread and bead edges, curiously shaped ones for handles and all sorts of spouts and mounts, also large heavy ones for the bodies of entrée-dishes and other forms too difficult to raise symmetrically by hand. Most of these dies were about a century old, and among them were many that had belonged to the firm whose mark identified them as the makers of the soup-tureen. We were delighted to find, as promised, the identical dies used for both handles and feet of the tureen.

In all these late pieces the small stampings, as I have previously stated, were in silver. We now learned that after the introduction of electro-plating, as the mounts became 
heavier and more ornate, they were cast in German silver, and the steel dies which had been so carefully cut at great expense fell into disuse. It was believed that those belonging to the earlier periods would never be wanted again, and they were nearly all sold to be melted down, but many belonging to the period between I8Io and 1850 were kept and are still used in the production of modern silver and sometimes plated ware.

One article that has preserved its popularity in the original form for a hundred years is the entrée-dish with cover, to be used as a pair of similar dishes when the handle is detached. We saw numerous old dies for shaping bodies, handles and mounts for such dishes, which continue to be among the most important appurtenances of the dinner table.

Leaving the dies reluctantly, we passed into another subterranean chamber where heavy stamping machines with the dies fixed in them were monotonously delivering heavy blows upon the parts which, after being trimmed off, were to be assembled further on. Then they would be soldered together and sent upstairs for the final process of filing down, cleaning, and burnishing. There were also the stamping machines already referred to with the small punches for piercing. A straight strip about two inches wide had just been pierced with an elaborate design to form the body of a coaster. In the hammering room one workman was flathammering a partially finished tray to get the surface perfectly smooth and hard, another was raising a circular sheet of silver into a bowl. The process of hand-raising has been so largely superseded in modern times by spinning and stamping that we were much pleased to be able to see a piece of 


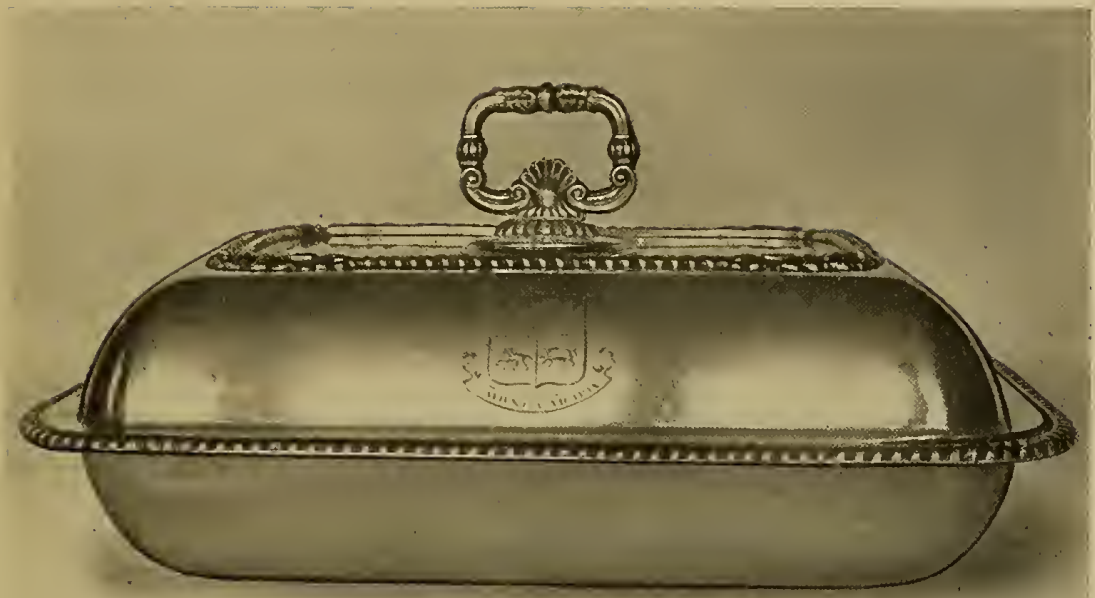

GADROON MOUNTED ENTRÉE-DISH WITH REMOVABLE HANDLE AND COVER WHICH MAY BE USED AS A SEPARATE DISH (I8I5)

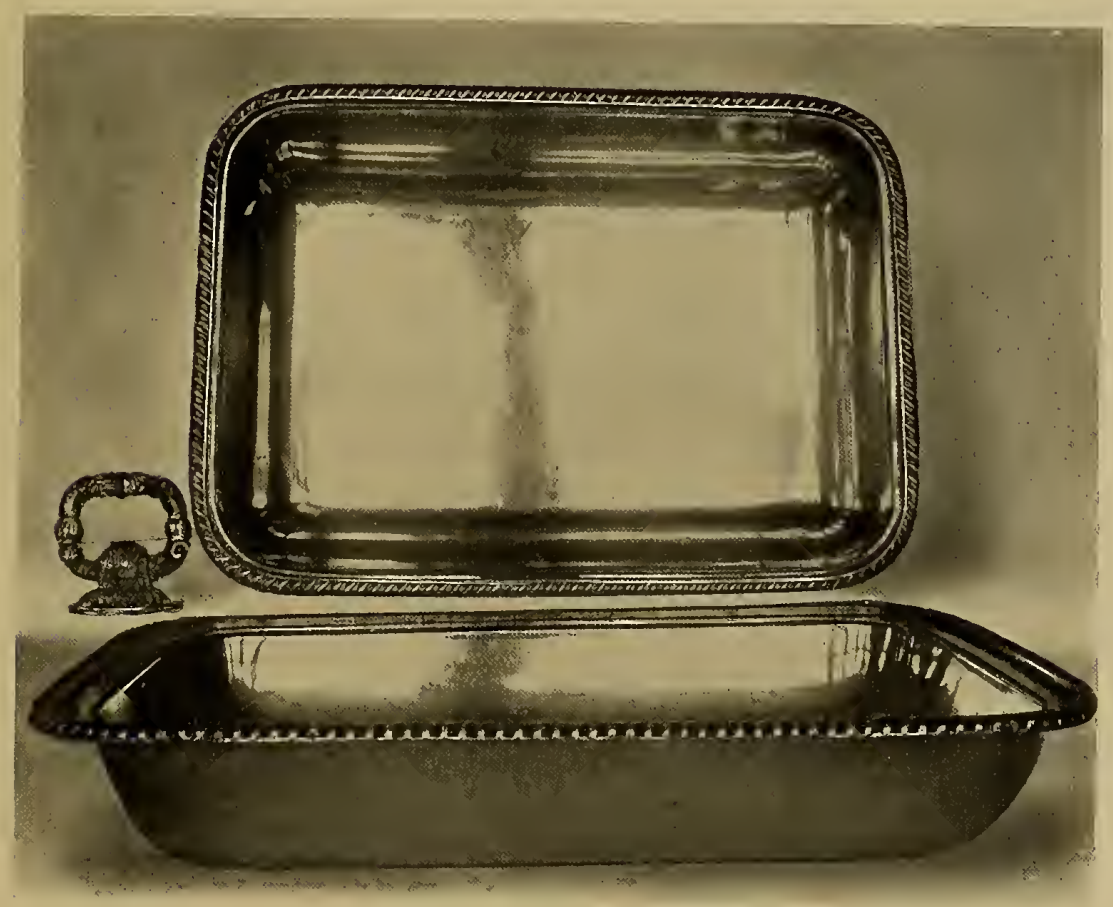

THE SAME WITH COVER AND HANDLE REMOVED 

silver in the actual process of being raised into a huge bowl.

We next came to the swages for shaping up the sides of trays, dishes, etc. The swaging tool or swage was a sort of press with an arm which exactly fitted the shaped bed. Such articles as dish covers, being too large to be formed by means of dies, were raised by hand, and the mouldings were shaped in a swage cut to the same curve as the profile of the moulding. The swaging was done by holding the edge of the article on the bed of the tool while the arm was brought down with repeated blows. At each blow the work was moved along very slightly.

We were interested to learn that a few plated articles had been recently produced by the old method. We saw a teatray of copper-rolled-plate with heavy silver mounts in process of construction. Pieces of this kind are much more easily reproduced than some of the earlier ones would be, but even this was not quite so skilfully done as the old one from which it was being very carefully copied. The makers said that it cost them nearly as much as if it had been made of solid silver, and that modern workmen would need years of training if they were to acquire anything like the proficiency of their predecessors in the very delicate manipulation required.

We were invited to look over a number of the old designbooks that are now highly prized by the firms that have preserved them, and we found the patterns from which a number of our pieces had been made. In a book containing designs by Richard Morton we found the exact illustration of our sugar and cream baskets, the proud possession of which we owe to the fact that my husband happened into a certain exchange club at the right moment to see them 
arrive. Even singly such baskets in good condition are rare, and a pair (the smaller intended for the cream, to be served with a ladle) is most exceptional. The finding of these was not beginner's luck, but a bit of the good fortune that is sure to follow a collector who looks for the best and persists until he finds it. 
Plate XXXV

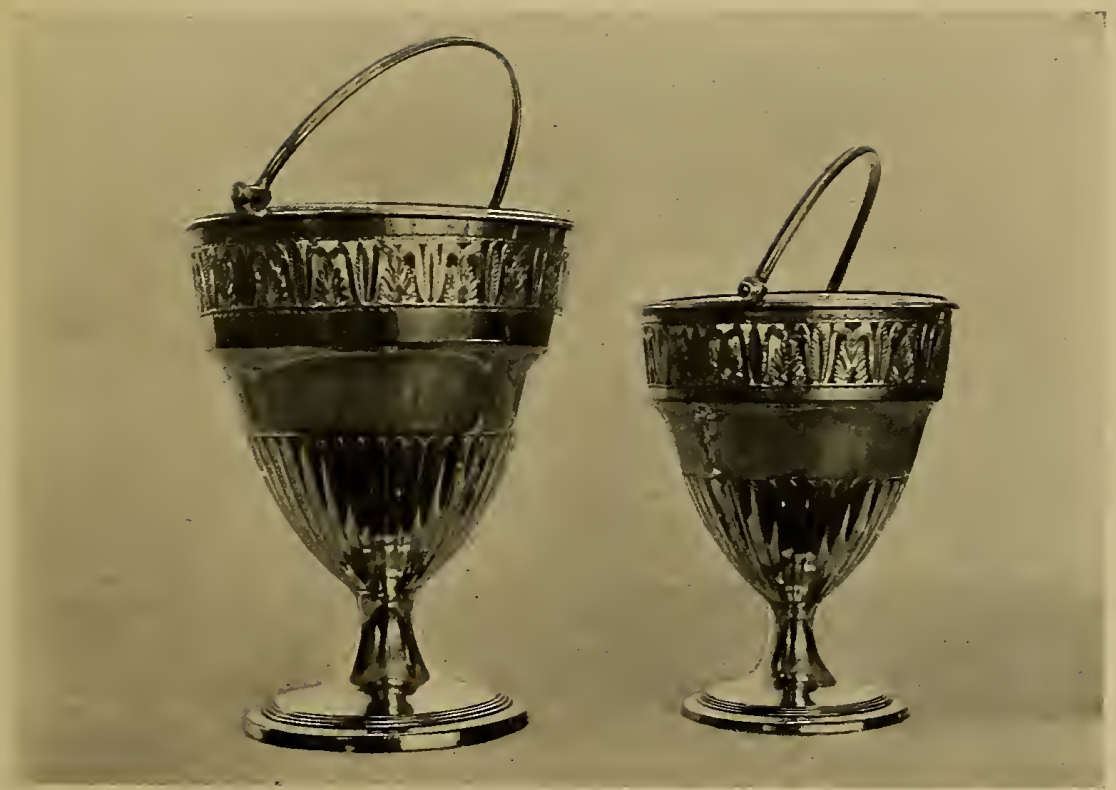

PAIR OF PIERCED AND CHASED SUGAR AND CREAM PAILS WITH BLUE GLASS LINERS (I785)

By Richard Morton 

Plate XXXVI

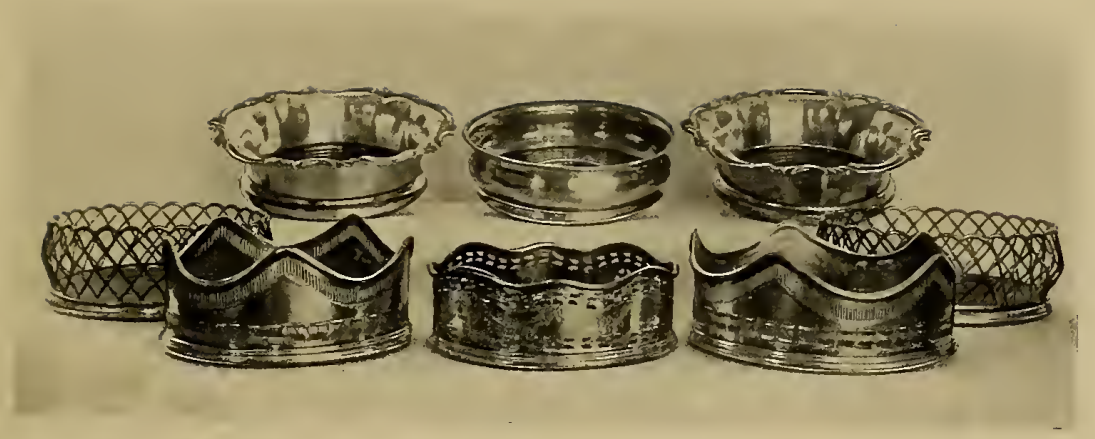

GROUP OF COASTERS OR DECANTER-STANDS (I780-I820)

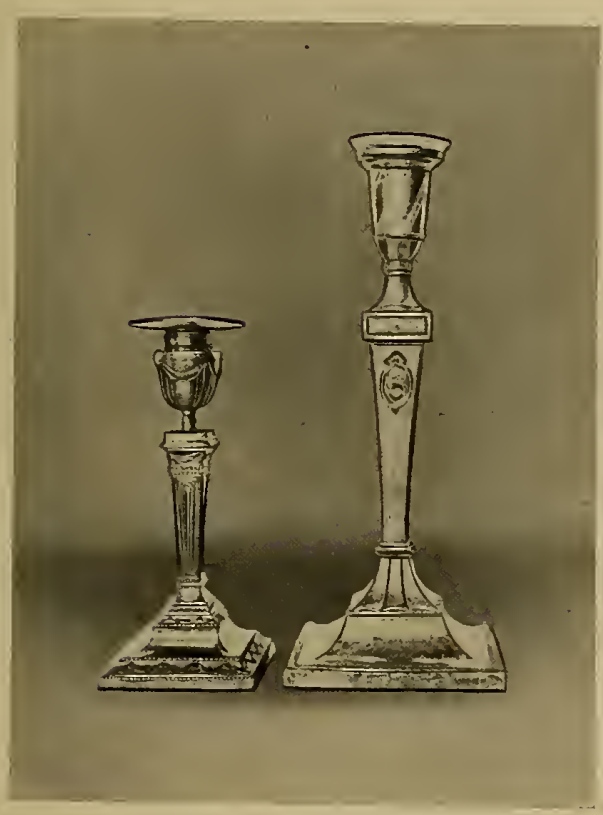

TWO ADAM CANDLESTICKS (I785)

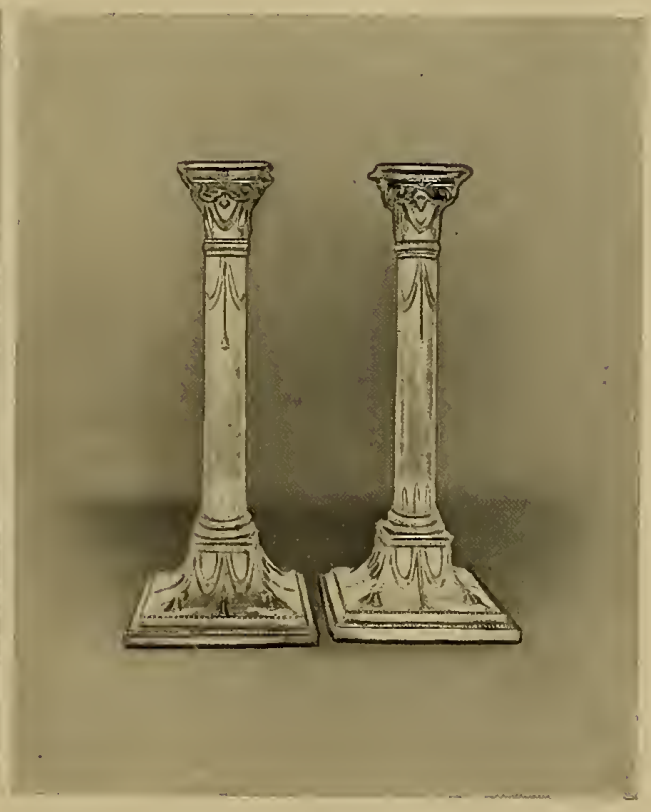

PAIR OF ADAM CANDLESTICKS (I779) 



\section{$\mathrm{X}$ \\ PERIODS AND STYLES}

7 HERE are so many current phrases relating to "period 1 furniture" and "periods" in almost everything, that the reader may naturally expect to be told of similar epochs named after great designers in silver and Sheffield Plate; but with the exception of Paul Lamerie, who died before the Sheffield-plating industry was really started, I know of no great silversmith whose originality of design or excellence of workmanship ever set the fashion in tableware, as Chippendale and Robert Adam set the fashions in furniture.

The best known and the most prolific of the French goldsmiths who went to England after the Revocation of the Edict of Nantes, and added much grace and refinement to the fine workmanship of the English craftsmen, Lamerie stands first in his influence upon the silverware of the eighteenth century in England. He was many years in business, made a great variety of articles with his own hands, and it is said that he never duplicated his best pieces. His work was copied long after his death, and it was probably his designs that furnished much of the inspiration for the work that helped to make Sheffield famous toward the end of the eighteenth century.

The first platers naturally copied such contemporary silver- 
ware as most easily lent itself to the new process. Later, as the plating industry became more important, it was the designs of the platers that set the pace for the silversmiths. This was especially true in the case of candlesticks, both as to design and method. The dies were cut for plated ware and then used to a less extent for solid silver.

The designers of plated ware had to consider in every instance the limitations prescribed by the use of the two metals, and it is interesting to see how the designs followed the development of the process and altered with each improvement in the art of manipulating. Of course it is conversely true that the styles already in fashion furnished the necessity and inspiration for the new methods.

To summarize in a general way, we may say that when Sheffield Plate was invented, the styles first adopted were the rather plain hand-raised bodies with small mounts struck from dies and hand-finished. Chasing of the George II type was the most common decoration.

Gadroon and bead edges, stamped in rolled plate from the dies already in use for silver, were a favorite form of decoration on early pieces. After 1785 these stampings were made of thin silver.

Pierced and chased decorations were popular from 1765 to about I795.

Wire-work was most in vogue from about 1790 to I810.

Any one familiar with the carved rams-heads, urns, swags and husks of classic origin on furniture designed by Robert Adam will at once recognize the Adam influence in Sheffield Plate. This was most conspicuous from I780 to I790, the period when perhaps the greatest number of beautiful pieces were produced. 


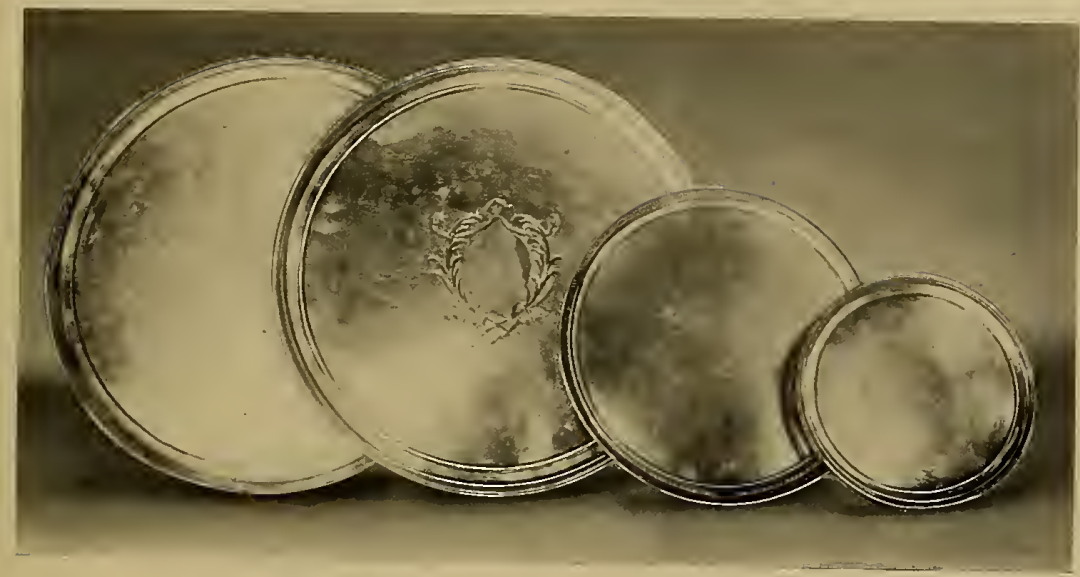

FOUR SALVERS WITH EARLY BEAD EDGES (I775)

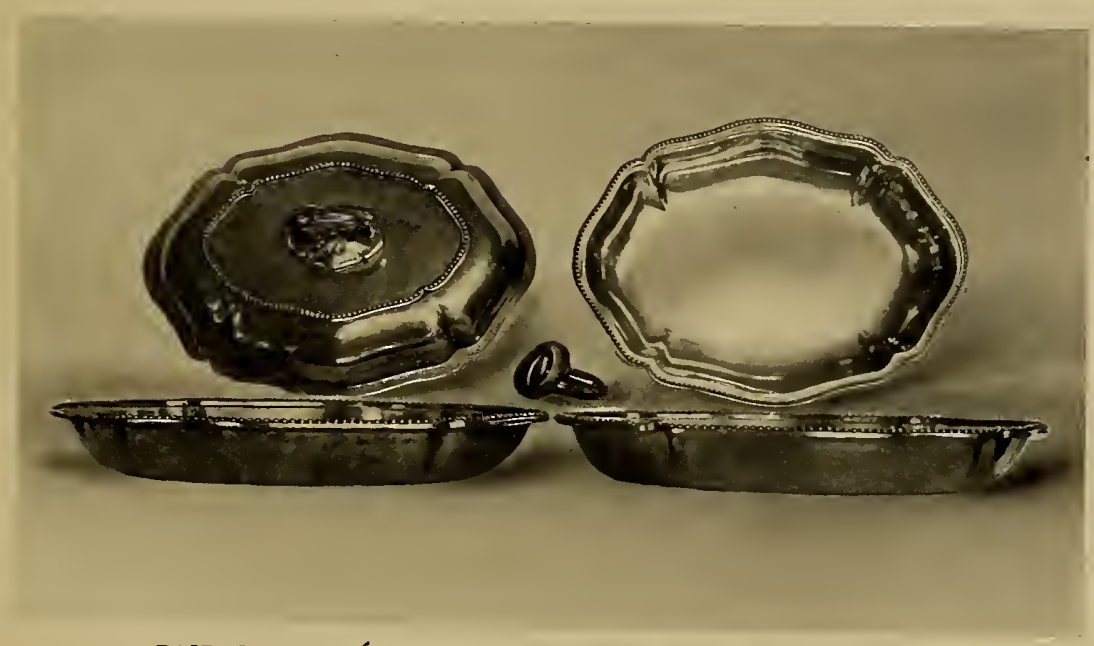

PAIR OF ENTRÉE-DISHES WITH LATE BEAD EDGES (I825) 

From the first, candlesticks were modelled on classic lines, the pillar forms being naturally suggested by classic architecture.

About I 800 , with the reversion to large forms relying more on fine lines than on ornament for their decorative qualities, piercing was revived in rather larger patterns and without the chasing that accompanied it in the earlier pieces.

Later still, bead edges and gadroons were again extensively used, but they were also on a much larger scale, and need never be confused with the early ones.

After silver stampings for mounts and borders became general, the designs grew more elaborate. First came the shells, leaves, and scrolls, introduced at intervals in conjunction with the heavy gadroons, then more elaborate and intricate festoons of fruit and flowers with large masks, etc., till in the Victorian period there seemed to be no fantastic combination of plants and animals too grotesque to be worked into the design. ' One of the most popular subjects for these heavy borders and mounts is the combination of grapes and vine leaves which is not always unpleasing. Fortunately for Sheffield Plate the worst of the over-ornate designs came into vogue after the invention of electro-plating, and our interest in the decline of good design ceases with that of the Sheffield Plate industry.

In determining the dates of Sheffield Plate specimens there are two good guides. One is the silverware of the period, the other is the record of improvements in the process. Even with these helps it is often difficult to say exactly when a piece was made, but it is more from a study of the articles with regard to the mode of manufacture than by their general style that we can estimate their date. 
Mr. Frederick Bradbury has spent many years collecting evidence as to the dates and probable makers of various pieces of Sheffield Plate. He has compared them with silver articles made in Sheffield, on which of course the hall-marks indicate both date and maker, and to his careful investigations we owe the greater part of our present knowledge on this subject.

Here are two coffee-pots which at first sight might appear to be contemporaneous, but a study of the workmanship shows them to be of quite different periods. The chased one is made like all the very earliest pieces, as its general style and George II chasing would suggest. It is wholly of copperrolled-plate, and the edges of lid and foot are simply turned under as in the case of the covered tankard previously described. Mr. Bradbury has identified a coffee-pot like this as having been made by M. Fenton \& Co. in I765. The plainer coffee-pot, while its more slender foot and ivory handle (which, by the way, is rare) would suggest a later date, was evidently copied from an earlier pattern, and may have been described as of "antique design." The silver edges on rim and lid show that it could not have been made before $I 785$.

I have given with each illustration what seems the most probable date of manufacture. In some cases this is undoubtedly exact, in others it is only approximate, but a study of all together should give a general idea by which the reader could place most articles of Sheffield Plate with a fair degree of correctness.

I repeat a few statements which will show the earliest possible dates when certain pieces could have been made.

Silver edges were first introduced in 1785 , and four years later other mounts began to be struck in thin silver. 
Plate XXXVili

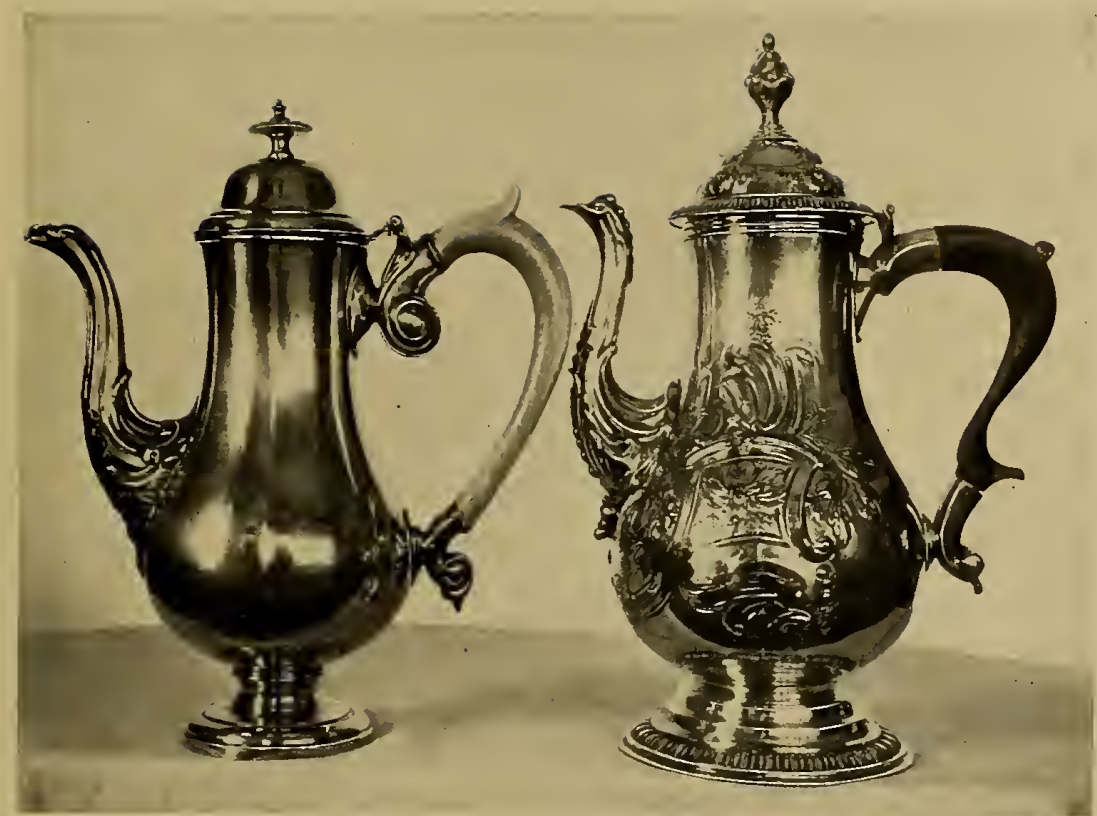

COFFEE-POT WITH IYORY HANDLE (I800)

DITTO WITH WOODEN HANDLE, CHASED IN THE GEORGE II STYLE (1765) (Marked. See Plate XLIX)

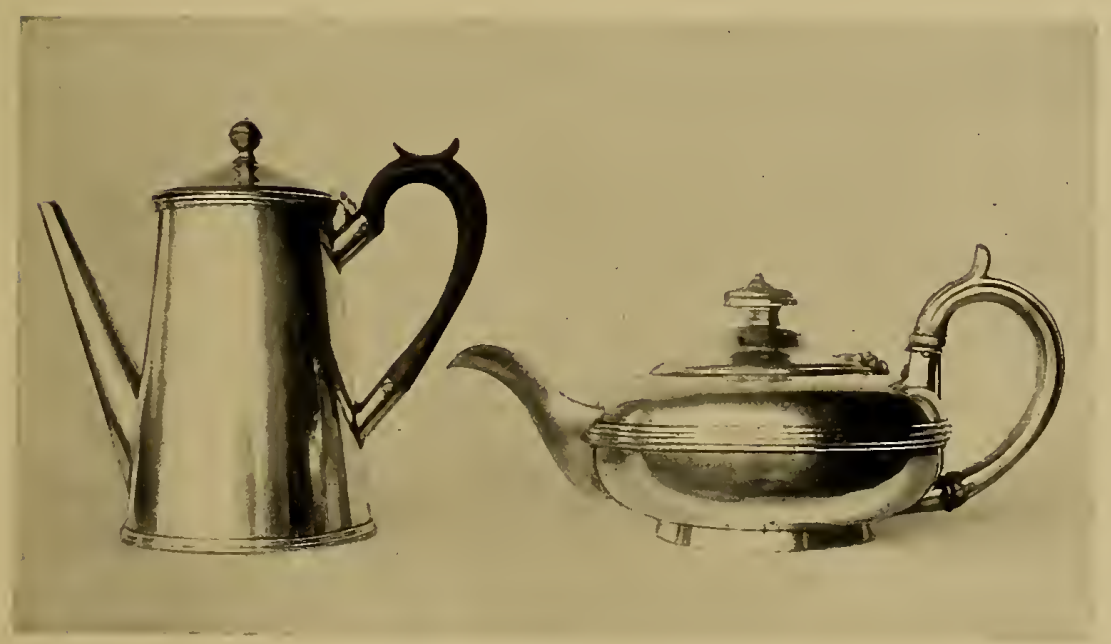

PLAIN COFFEE-POT (I8Oo)

"ROMAN LAMP" TEAPOT (I800). (See page 68)

By Matthew Boulton 

Engraved silver bands were first used as decoration in I 789 .

Shields of heavier plate for the engraving of coats of arms were "let in" in 1789.

"Rubbed-in" shields were not applied until about I8Io.

Teapots with ball-feet were not made before $\mathbf{I} 800$.

The first patent for telescope candlesticks was taken out in 1797.

The first folding toast-rack was patented in 1807 .

Silver edges were done away with in I824 when Samuel Roberts invented a method of applying the silver mounts in such a way as to give the appearance of a solid silver article.

German silver began to be used as a substitute for copper in fused plate about 1830 .

Electro-plating was invented in 1840 and had practically superseded Sheffield-plating by 1850 . 


\section{$\mathrm{XI}$}

GILDING AND CLOSE-PLATING

$A S$ gilding was always used more or less in connection A with silverware, so it was applied to Sheffield-plated articles. The insides of sugar-basins, cream-jugs, small trays, drinking-cups, etc., were often gilt.

The process used was an old one known as mercurial or fire-gilding. As a full description may be found in any good encyclopedia, I will only state briefly that it was done by means of an amalgam containing gold and quicksilver. The copper or silver surface to be gilt was treated with a nitrate of mercury solution, then rubbed over with the gold amalgam which was thick like paste. The article was then subjected to heat, which caused the gold to adhere and the mercury to evaporate.

Nowadays gilding is done by immersing the article in the electric bath, but previously to the invention of electroplating fire-gilding was the only method. On silver-plated articles the portion to be gilt was usually done directly on the copper. Quantities of small articles were gilt all over by this process with a result far more durable than by the modern method. 


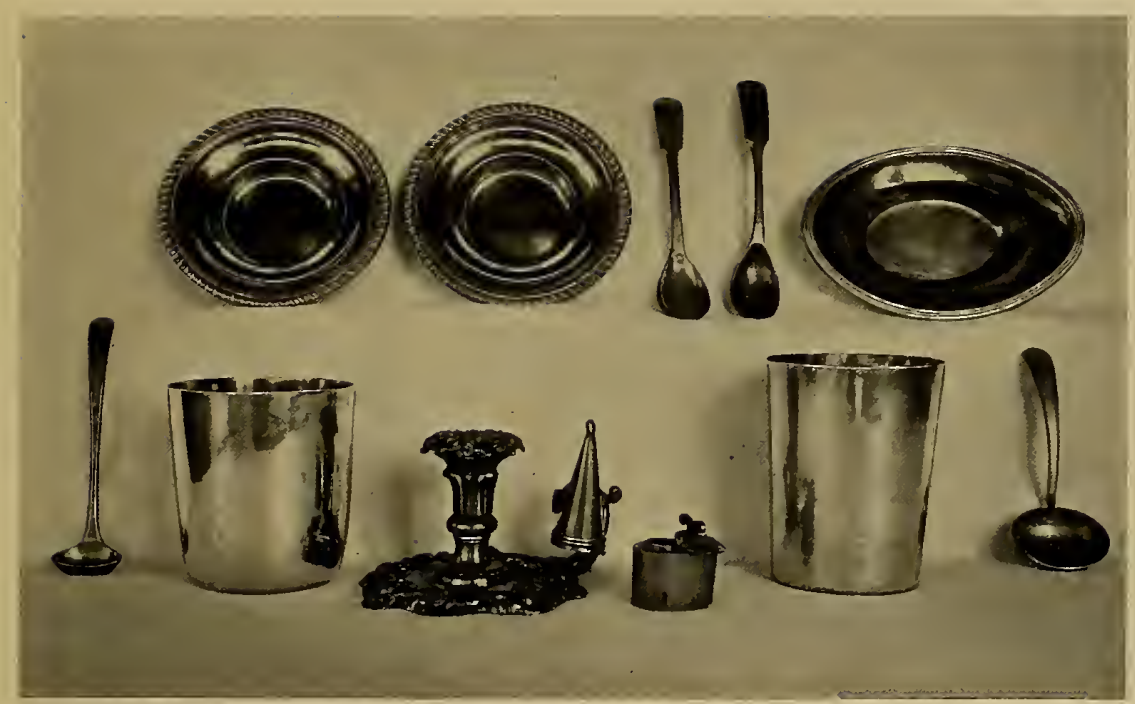

PAIR OF GILT-LINED GADROON MOUNT SWEET-DISHES (I820)

TWO GILT-ON-COPPER SALT-SPOONS (I800) (The larger one is marked. See Mark, Plate LI) GILT-LINED SWEET-DISH WITH SILVER THREAD EDGE (1790) GILT-ON-COPPER MUSTARD-SPOON (I800) GILT-LINED TUMBLER (I800) TAPER-STICK, GILT-ON-COPPER, WITH THE EXCEPTION OF BOTTOM OF STICK AND INSIDE OF EXTINGUISHER, WHICH ARE SHEFFIELD-PLATED (I830) INK-POT, GILT-ON-COPPER
GILT-LINED TUMBLER ( $\mathrm{I}_{7} 80$ )
LADLE WITH GILT-LINED BOWL (I790) 

I read in a book by an American writer dealing with the subject that Sheffield-plated ware is spoken of in England as "close-plated." It is difficult to see how such a blunder could have been made by any one who had investigated the matter in the slightest degree. Sheffield-plating and closeplating are two radically different processes. By the one silver is plated on copper before the article is made up, by the other an article is made of steel and silver-plated afterwards.

\& Close-plating, like gilding, was often done in connection with Sheffield-plating. It was used for articles or parts of articles that were better made of steel on account of its greater strength and hardness. I hope I have already made it clear that in the case of rolled plate the silver and copper are joined by fusion, the melting process being carried just far enough for the two metals to become one where their surfaces meet. This is made possible by the fact that the melting-points of silver and copper are not very different; but in the case of steel, which has a much higher melting point, plating by this process would be quite impossible.

Sheffield from its earliest days had been famous for its cutlery, and long before the invention of rolled plate the process of close-plating was applied to knife-handles, bridlebits, and other small articles. It was simply an ingenious method of soldering, and is essentially the same as that by which thousands of steel knives are silver-plated to-day in the United States. The article, or part to be plated, is filed very smooth and very thinly tinned by dipping in melted solder. Then a piece of silver-foil is fitted on and rubbed or hammered until it adheres. Now a hot soldering-iron is rubbed over the surface to melt the solder and make the 
union more perfect, and finally powdered rosin is sprinkled on the surface and the whole article heated over a charcoal fire to flux the tin. This, in a general way, is the manner in which an article is close-plated and made ready for the various processes of smoothing and finishing.

I have given a few illustrations of such articles as were made in close-plated ware a century or so ago. In cases like those of snuffers, the blade portion was sometimes of closeplated steel and the handles of Sheffield Plate. More frequently snuffers were made throughout of the former, and occasionally one finds a pair made entirely of rolled plate.

Nowadays close-plating is confined to a small class of articles including harness-fittings and silver-plated knives.

Although close-plated articles were and are still made in Sheffield as well as Birmingham and other English towns, it is never called Sheffield Plate, a term that is applied only to the old rolled plate and (unfortunately) to imitations thereof. 


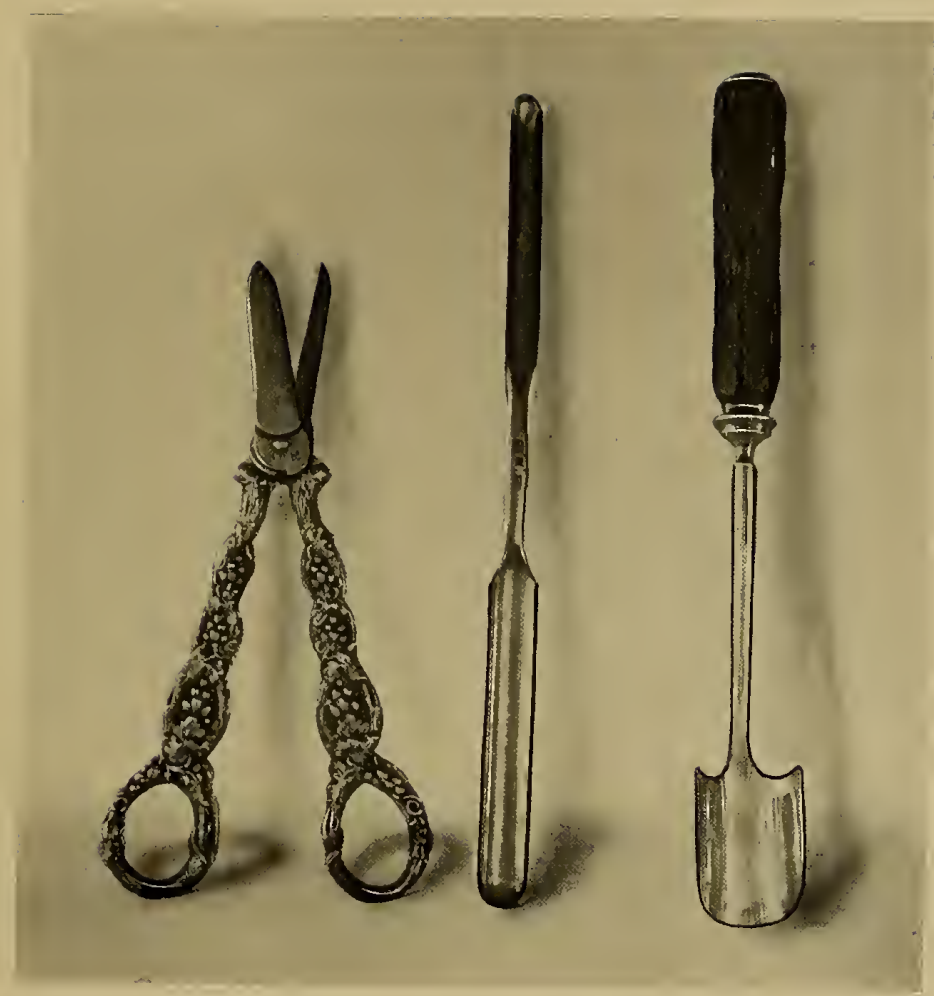

Plate XL

CLOSE-PLATED GRAPE-SCISSORS (I825). (Marked)

By Gilbert, a Close-Plater of Sheffield

CLOSE-PLATED MARROW-SCOOP (I8I5). Also by Gilbert

CLOSE-PLATED CHEESE-SCOOP (1830)

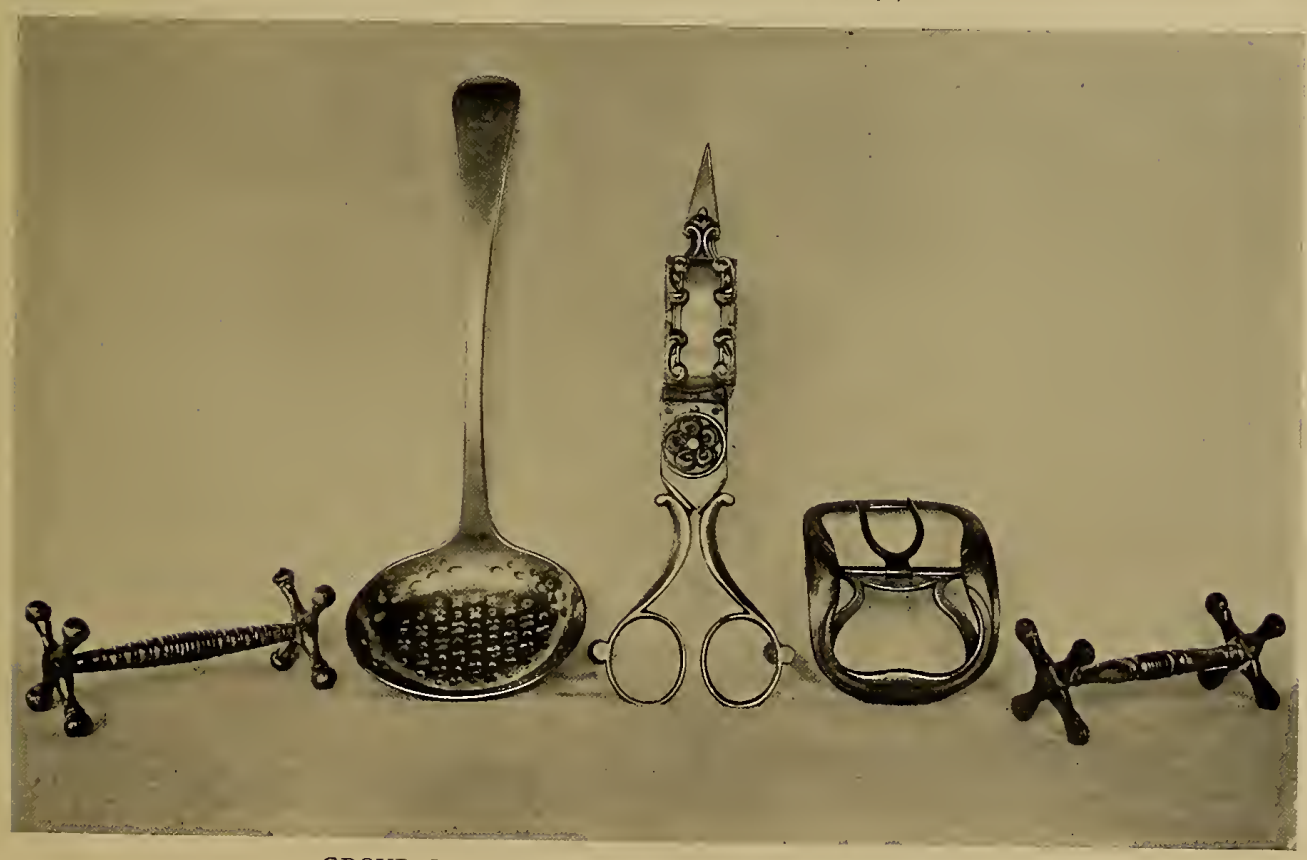

GROÜP OF CLOSE-PLATED ARTICLES (about I800) 

Plate Xli

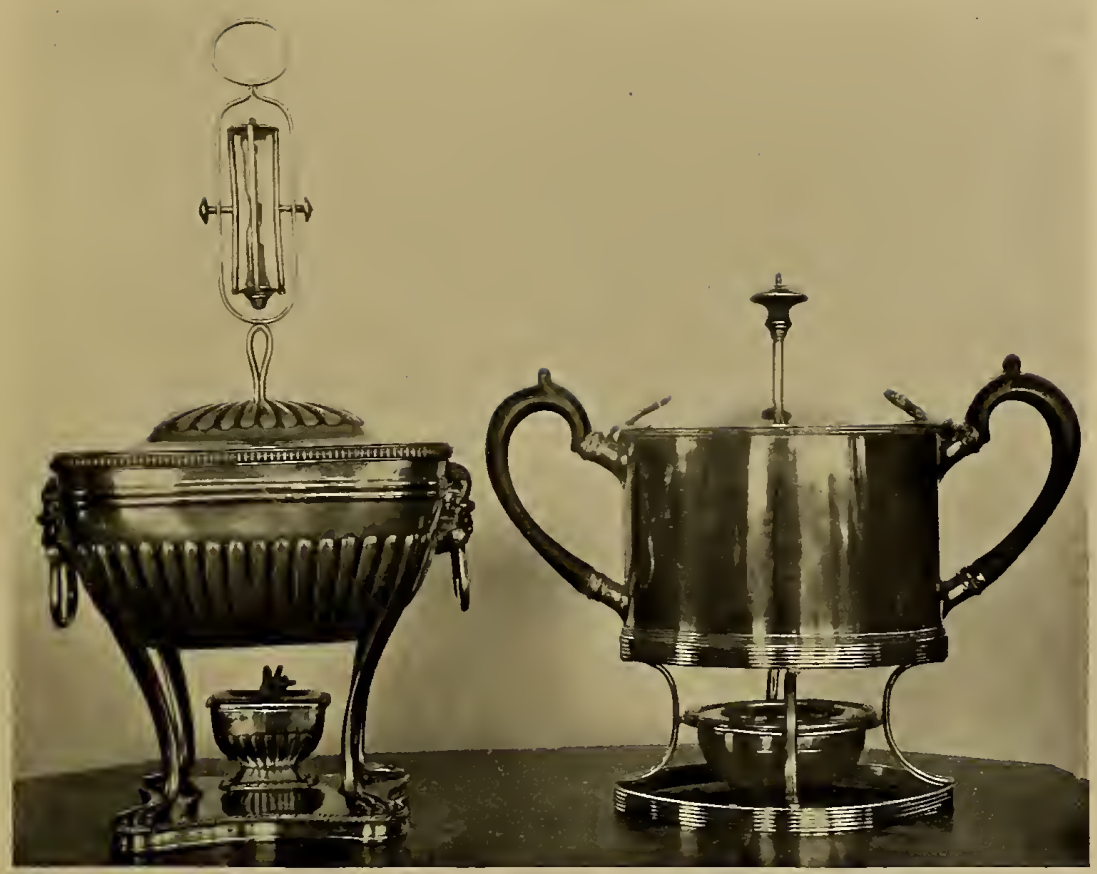

EGG-COOKER WITH SPIRIT-LAMP AND SAND-GLASS (I8IG) EGG-COOKER WITH SPIRIT-LAMIP (I800)

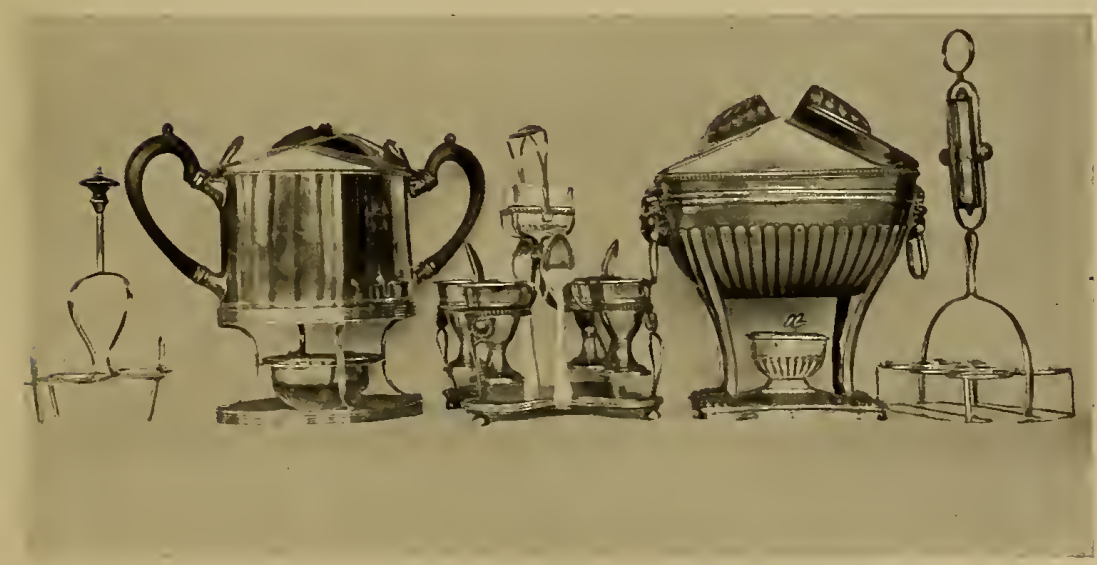

THE SAME COOKERS OPEN, WITH EGG-FRAMES REMIOVED STAND CONTAINING FOUR EGG-CUPS, GLASS SALT-CELLAR AND RINGS FOR FOUR SPOONS (I8IO) 



\section{XII}

SOME CURIOUS PIECES FOR SPECIAL PURPOSES

FTER reading some old lists of articles made by cer-
tain firms, I decided that our collection, to be complete, must contain a specimen of each article manufactured. This ambition was effectually curbed when I realized that such a collection must include such pieces as a huge supper service that apparently wanted only the animals to make it a merry-go-round, a barber's dish, coach lamp, presentation trowel and mace, ear-trumpets, bridle-bits, spurs, stirrups, etc., and even counterfeit money. We are now content to know that the manufacturer's lists included a marvellously varied number of objects, and to acquire such pieces as appeal to us by their beauty and associations, or represent interesting developments in the industry.

I have been surprised to learn that many of the things I had regarded as distinctly modern, such as the pieces with spirit lamps, were in frequent use in Sheffield Plate days.

What could be more up-to-date than the egg-cookers that were made a century ago? Unless one wishes to substitute an electric contrivance for the alcohol lamp, there is no better arrangement to-day for boiling eggs on the breakfast table. The frame with egg-cups, glass salt-cellar in the centre, and rings for the spoons, is also as useful to-day as it ever was, provided the eggs are eaten in the English way. 
The coffee-biggin with its spirit-lamp is another example of an old article that seems very modern. There is a ring on the inside near the top of most biggins to hold a muslin bag, but some of them actually had metal percolators.

Although I never saw one that I cared to possess, kettles with stands containing spirit-lamps were made in Sheffield Plate as early as I795, but they do not seem to have been very common, and the later ones are often of unattractive design. Small compact ones were occasionally made for use when travelling.

Chafing-dishes in old plated ware are unusual, and we were more than pleased to find this pair in excellent condition. Their former owners were evidently less inclined than myself to tempt Providence by trying to find the limit of their cooking possibilities. We first tried such things as Welsh rarebit, and found the results so satisfactory that I was constantly tempted to try things that require greater and longer heat, with the result one day that tiny beads of solder appeared around the edges of the mounts. I extinguished the flame in time to prevent any real damage, and now confine myself to less ambitious performances which can be accomplished without risk. I have never seen chafing-dishes included in any manufacturer's list, and I should be glad to know just what use was made of these by their original possessors. I have seen an illustration of a Sheffield Plate dish-warmer which is almost identical in pattern with these chafing-dishes. The heater in that case may be a removable iron one, or possibly an arrangement for heating by means of charcoal. These dishes furnish an excellent example of the beautiful workmanship which makes some of the late pieces so deservedly popular. 
Plate XliI
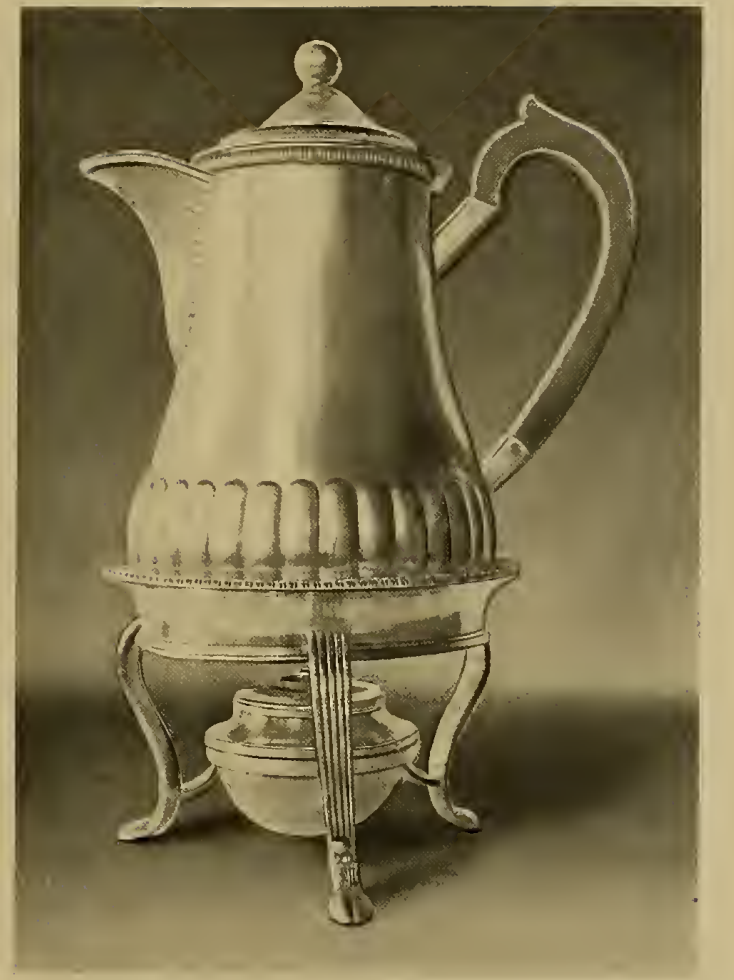

COFFEE-BIGGIN WITH SPIRIT-LAMP (I800)

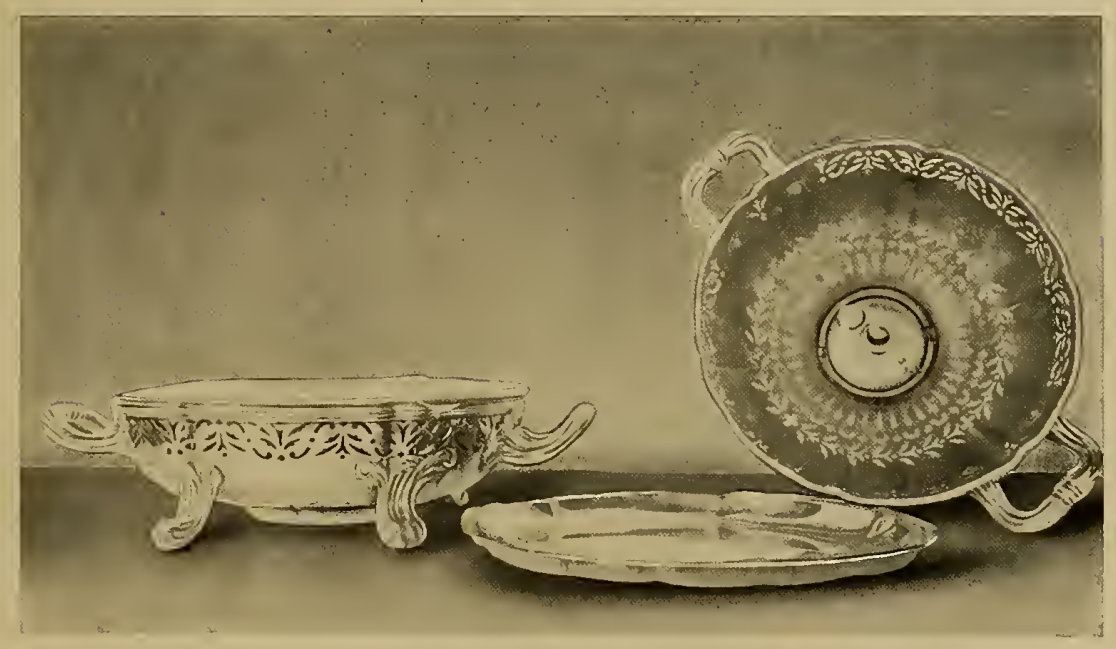

PAIR OF PIERCED CHAFING-DISHES WITH REMOVABLE SPIRIT-LAMPS (I830) 

Cheese-toasters seem to have become quite obsolete, but they were in great demand in the earlier part of the last century. The one shown in the following illustration represents what was probably the best pattern. The main body of the dish is a closed compartment for hot water which is poured in through the hollow handle after the wooden portion has been unscrewed. There are six little square dishes which exactly fit in the upper portion of the toaster, and pieces of toast covered with cheese are placed in these. The lid is held open by the chain attached to the handle and the dish is held in front of the fire till the cheese is toasted. The bright lid, reflecting the heat downwards, helps to accomplish the quick and even toasting. Cheese-toasters were sometimes shaped like entrée-dishes with the handles:at the ends, but these could not have been so convenient, either in cooking or serving the savory.

The pair of beautiful little tureens with heaters represents a method commonly used for keeping food hot in entrée, breakfast, and supper dishes. The heaters were sometimes filled with hot water or sand, but more frequently the inside, which was tinned, contained a metal framework holding a removable bar of iron which was heated in the fire. The perforated top fitted tightly and the tureen or dish containing the food was placed upon it. Wooden feet usually protected the table from the heat.

Similar contrivances were used in tea-urns. An upright hollow. cylinder was fastened into the bottom of the urn, and an iron heater with a hook or ring at the top fitted into it. Occasionally the water in tea-urns was kept hot by means of charcoal, but very rarely were Sheffield-plated urns fitted with alcohol lamps. 
Dish-crosses, or stands, were very popular as early as I 770 . The legs slide back and forth over the square rods, and the arms of the cross may be extended at any angle so that the stand may be adjusted to fit any dish, food being kept hot by the spirit lamp in the centre.

It is popularly supposed that the very few Old Sheffield dish-rings in existence were produced, like the silver ones, in Ireland; but it is now believed by those best informed that none of the old plated ware was ever made in Ireland, but that, as the English factories produced articles in the French style for export to France, so they copied the Irish silver in plated ware to be sent to Ireland.

The dish-ring (often incorrectly called a potato-ring) was purely an Irish institution. Usually made in silver, and handsomely wrought, it constituted the pièce-de-résistance on a gentleman's dinner table. Upon it was placed the earthenware broth-bowl, then in turn the wooden potato-bowl, glass fruit dish and silver punch-bowl. They were elaborately embossed, pierced and sometimes gilt. They are of fairly uniform shape and size, standing about seven inches high.

The dish-ring illustrated must have had an eventful history. It had evidently fallen into the hands of people who knew nothing of it, for it was sold in the London market twenty years ago for ten shillings, the seller suggesting that it be cut in two and made into a pair of coasters! Fifteen years later the lucky buyer offered it for sale, and we were glad to buy it for sixty times the former price, a welldeserved profit for the knowing lady who had rescued such a rare and beautiful specimen from imminent destruction.

The inkstands of a century ago were not unlike those of the present day in general appearance, despite the fact that the 


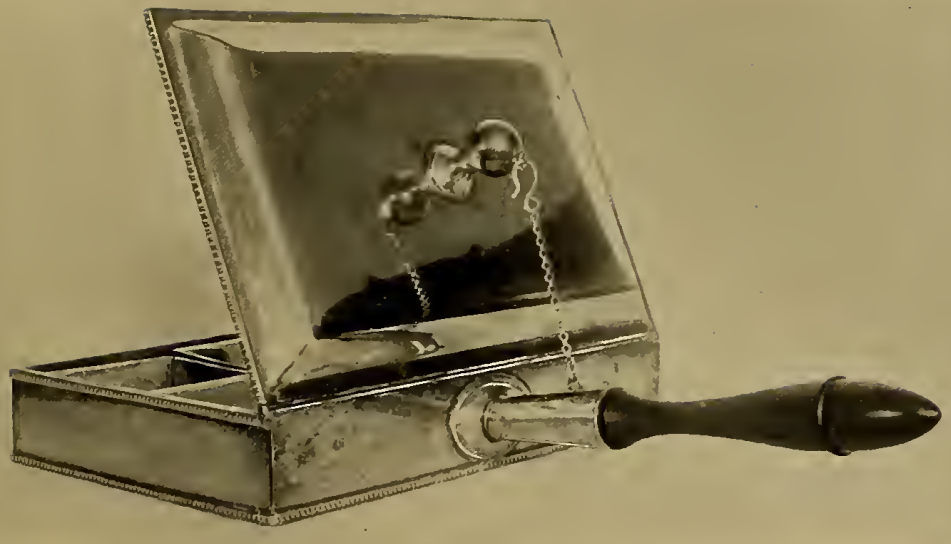

CHEESE-TOASTER WITH GADROON MIOUNT (I800)

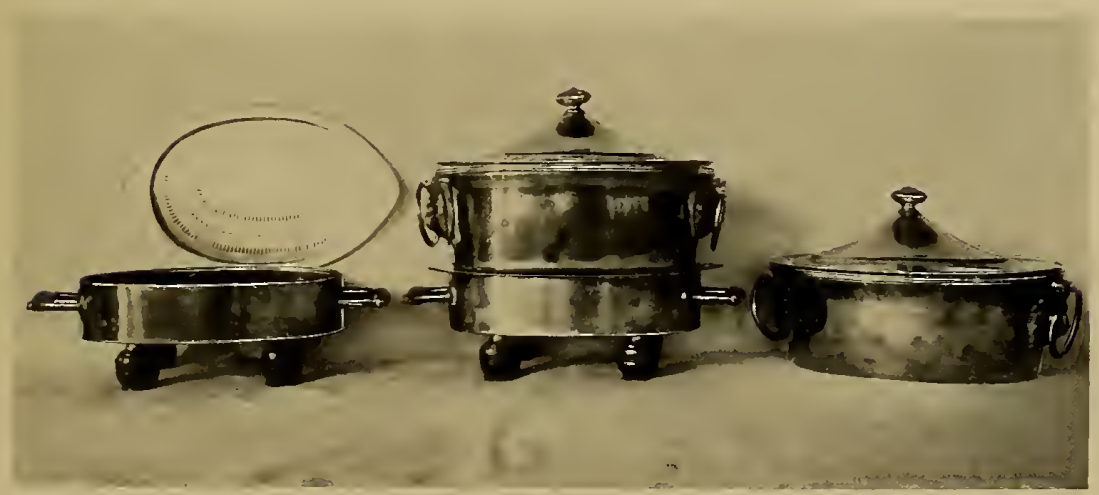

PAIR OF SAUCE-TUREENS IVITH HEATERS HAVING PERFORATED COVERS (I810) 


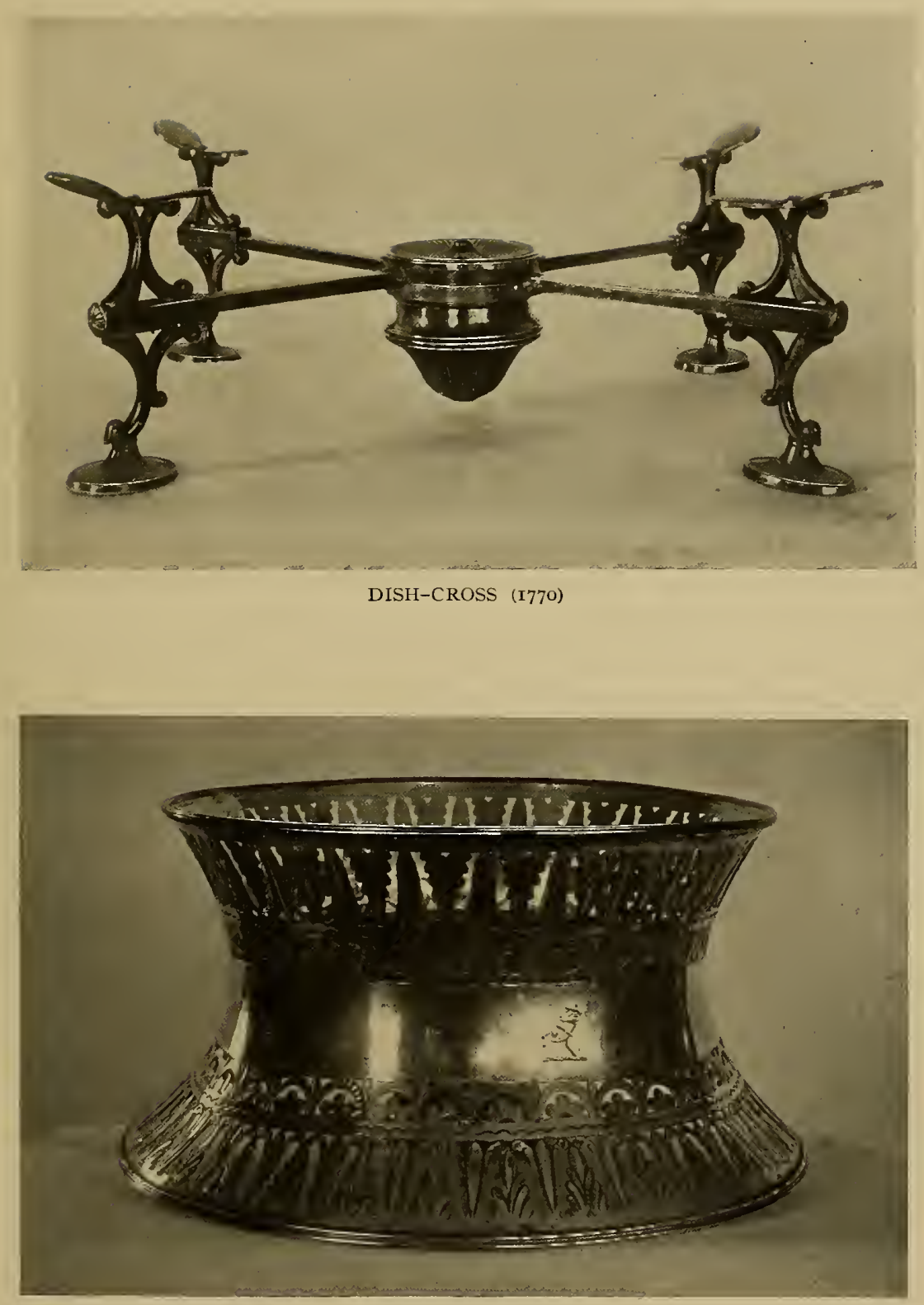

DISH-RING ( 1780$)$

By Richard Morton 

ink is the only appurtenance that remains the same. Taperstick, wafer-box, and sand-bottle have disappeared with the quill pen, but the old boxes and bottles are readily adaptable to modern needs, and complete specimens of these old inkstands are not only pleasant reminders of the ways and means employed by our grandparents when they wrote the delightful epistles now tucked away in the old secretary drawers, but they are desirable possessions from the point of view of utility.

The little stand with wafer-box in the centre, surmounted by a taper-stick, is a usual type. Sand from one of the bottles was sprinkled on the page to dry the superfluous ink, and the tiny wafers sealed the envelope long before blotting paper and "gummed edges" were thought of.

The soy-frame is another article that has now become obsolete. The words "soy," "kyan," anchovy, lemon, "garlick," ketchup, sometimes found on the labels, show how tastes have altered. "Soy" was the prime sauce in those days. It was made from the soy bean, a native of China, and resembled ketchup.

The little soy-frame illustrated opposite the next page has its old bottles of copper-blue glass, and it retains four out of five of its labels.

The one shown in Plate LX is perhaps a little less interesting. Its bottles of clear cut glass are attractive, however, and the wire-work frame is well designed. It has rings to hold the stoppers while the bottles are in use.

Soy-frames were made with from two to six bottles, and are suitable little cruets for modern use. Not being in great demand, they are comparatively cheap.

It seemed an important matter a hundred years ago that 
food and drink should be served at the right temperature, and while many devices were invented for keeping things hot, the wine at least had to be kept cold.

The Sheffield Plate wine-cooler or ice-pail first made its appearance about $\mathbf{I} 780$, but only a few of them were made until the nineteenth century. The first ones seem to have been adapted from the decanter stands or coasters, the main difference being that the ice-pail was larger and provided with an inside lining round which ice could be packed.

The pair illustrated are of this early type. They are finished with green baize at the bottom and were intended to slide along the table like the coasters, some of which were provided with wheels.

In the nineteenth century the wine-coolers became more imposing. They were much larger, and were usually made in handsome vase or urn shapes, to be kept on the sideboard, where they occupied the place of honor formerly held by the mahogany knife-boxes of the Georgian period. Beautifully shaped and heavily mounted, some of these late wine-coolers represent the very climax of the Sheffield plater's art, both for elaborate design and workmanship. The most ambitious productions I have ever heard of in Sheffield Plate are winecoolers made about 1830 in the form of the famous Warwick Vase. Some day we hope to possess at least one of them. 
Plate XLV

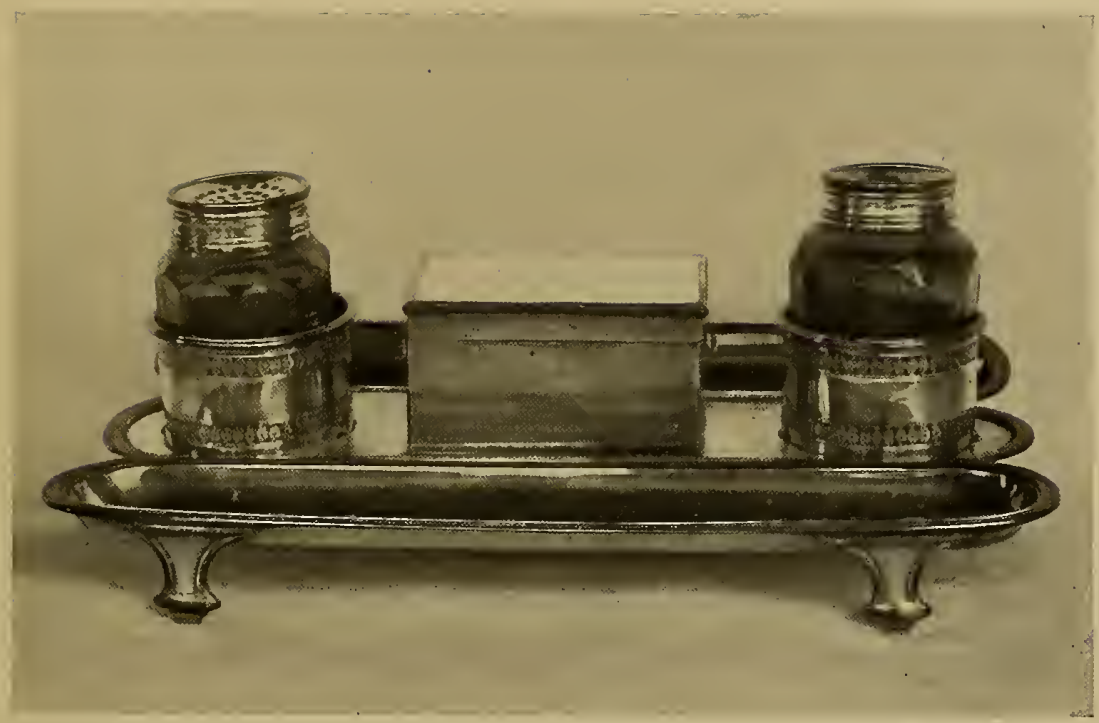

INKSTAND WITH TWO PEN-TRAYS, PIERCED AND CHASED BOTTLEHOLDERS, AND PLAIN WAFER-BOX (I790)

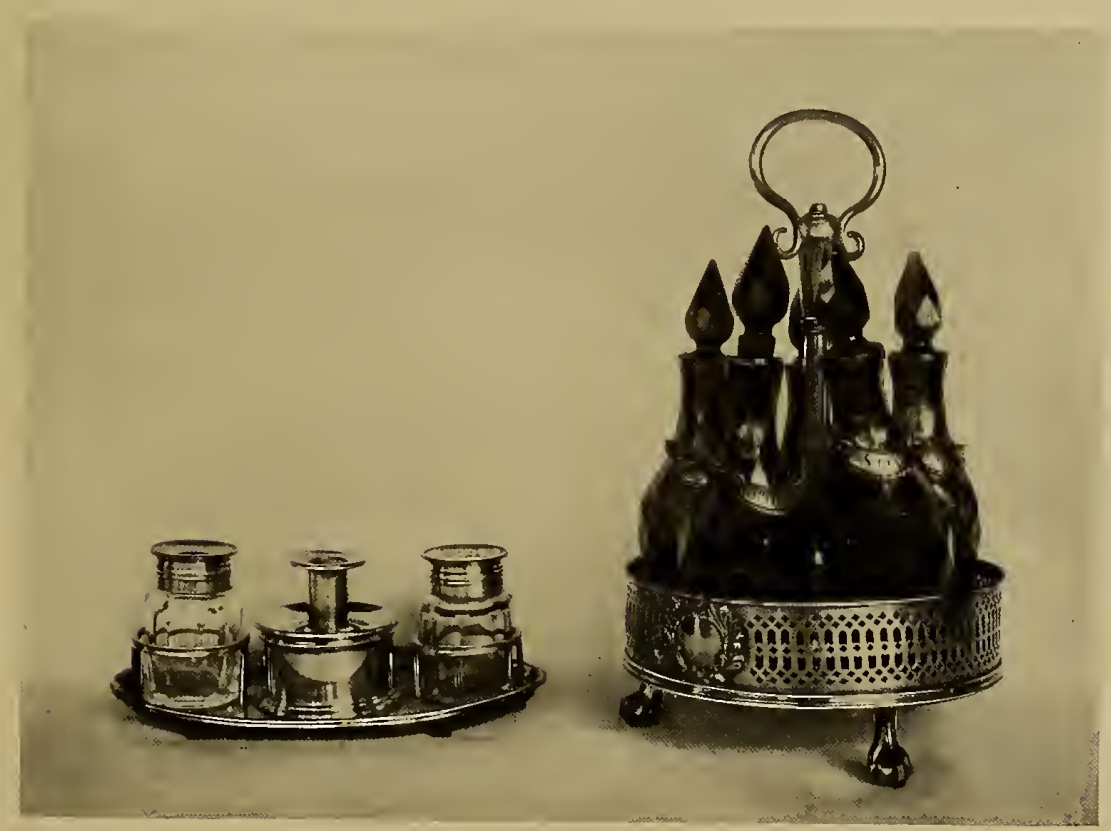

SMALL INKSTAND WITH CUT-GLASS BOTTLES (I8Q0) SOY-FRAME (1776). By Richard Morton 



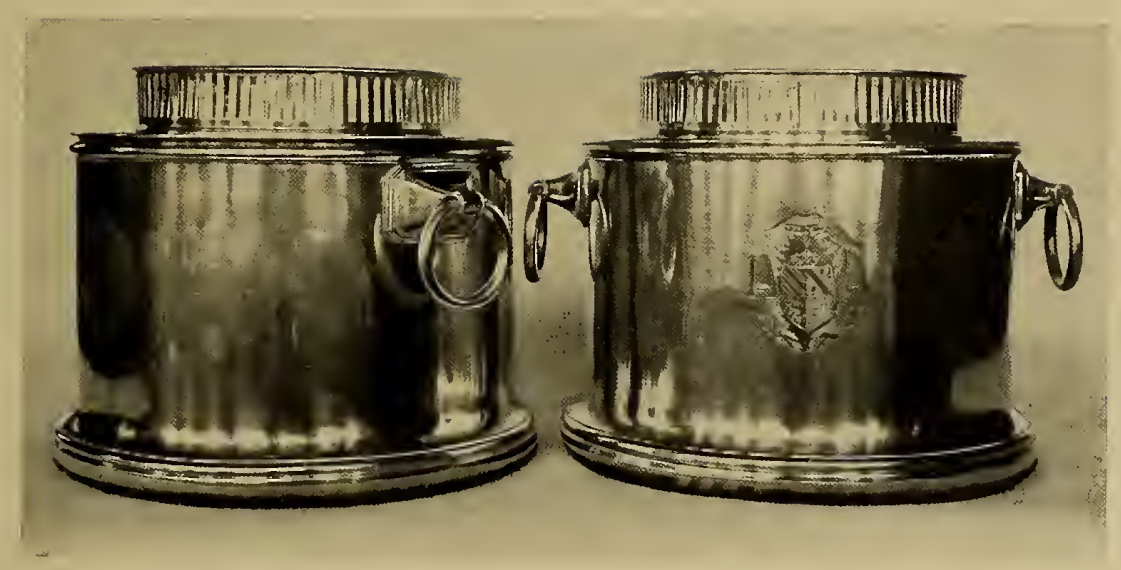

PAIR OF WINE-CCOLERS (I790) 



\section{XIII}

SMALL MOUNTS AND OTHER ACCESSORIES

$\mathrm{T}^{\mathrm{T}}$ is frequently a matter of surprise to collectors to find 1 how extensively Sheffield Plate was substituted for silver in the matter of mounts of one kind or another on articles made chiefly of other materials. It is true, however, that some of the early platers, notably Thomas Law, made a specialty of such work, and very handsome pieces of stone and jasper ware were mounted by them in Sheffeld Plate. Matthew Boulton of the famous Soho factory in Birmingham is said to have been a great friend of Josiah Wedgwood, and he did a large business in mounting the famous Wedgwood pottery with both silver and Sheffield Plate.

There are some very beautiful specimens of this mounted pottery in existence, but they seem to be too highly prized by their present owners ever to come into the market, and we have always regretted our inability to find either a vase or a jug with the Flaxman figures in high relief for sale. Cocoanuts made into covered boxes mounted with silver are not infrequently met with, but the one here illustrated is the only one I have found mounted in Sheffield Plate. The same may be said of the Sheffield Plate mounted reading-glass in tortoise-shell frame. 
Beakers made of horn would seem unfinished without some sort of a metal rim, and they are about the commonest examples where plated ware has been used in this way. One of those illustrated has also a Sheffield Plate lining.

Another auxiliary use for plated ware was for handles and escutcheons. Some of these may be seen on fine pieces of furniture belonging to the Sheraton period. The drawers of small writing-desks are often finished in this way, and such pieces as tea-caddies or coffers handsomely inlaid or veneered with rare woods frequently have both handles and escutcheons of Sheffield Plate.

One of the most interesting pieces in our whole collection is the metal tea-tray painted in the style of Angelica Kauffmann by an artist of the Flaxman school about 1800 . It is mounted with a handsome Sheffield Plated border of classical design. The handles were evidently of the same material, but some vandal has filed them off, presumably for no better reason than that one of them had been broken. We shall probably have them replaced some time by silver ones. 


\section{Plate Xlvil}

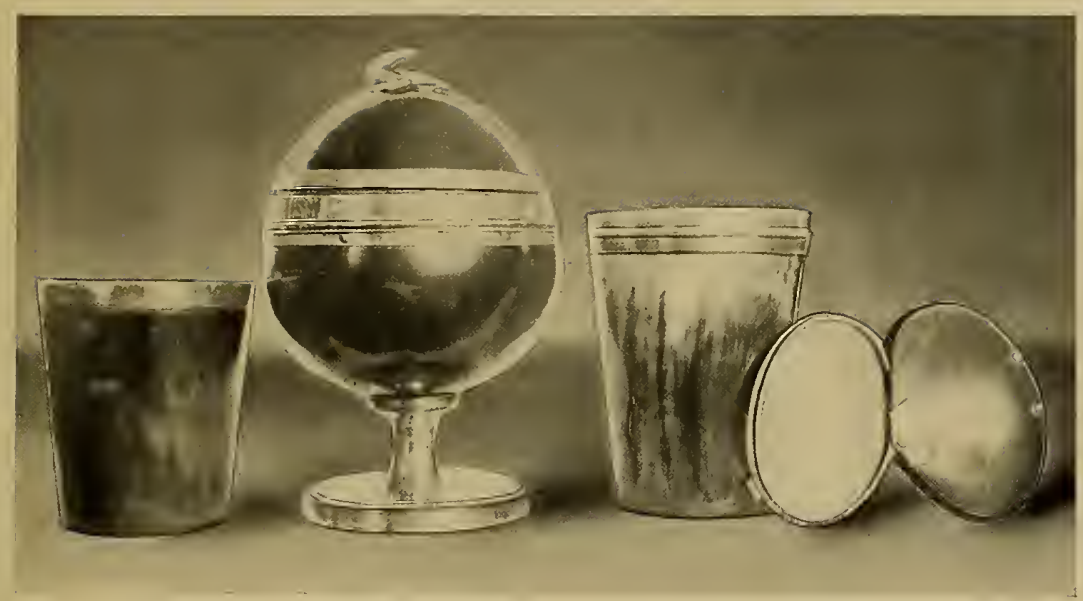

TWO HORN BEAKERS MOUNTED IN SHEFFIELD PLATE (I770) COCOANUT DITTO (I830)

READING-GLASS (I830)

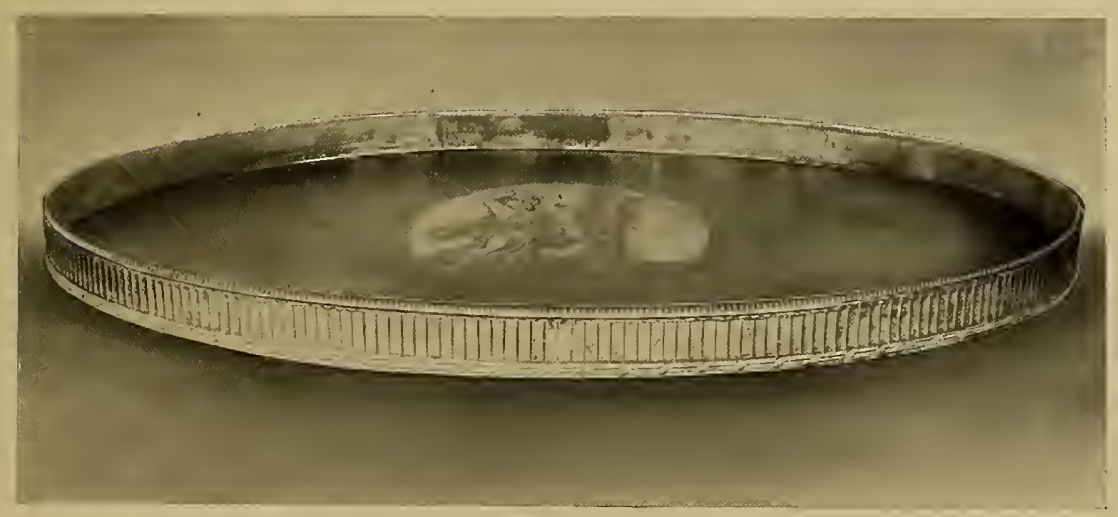

PAINTED TEA-TRAY WITH SHEFFIELD PLATE BORDER (I780) 



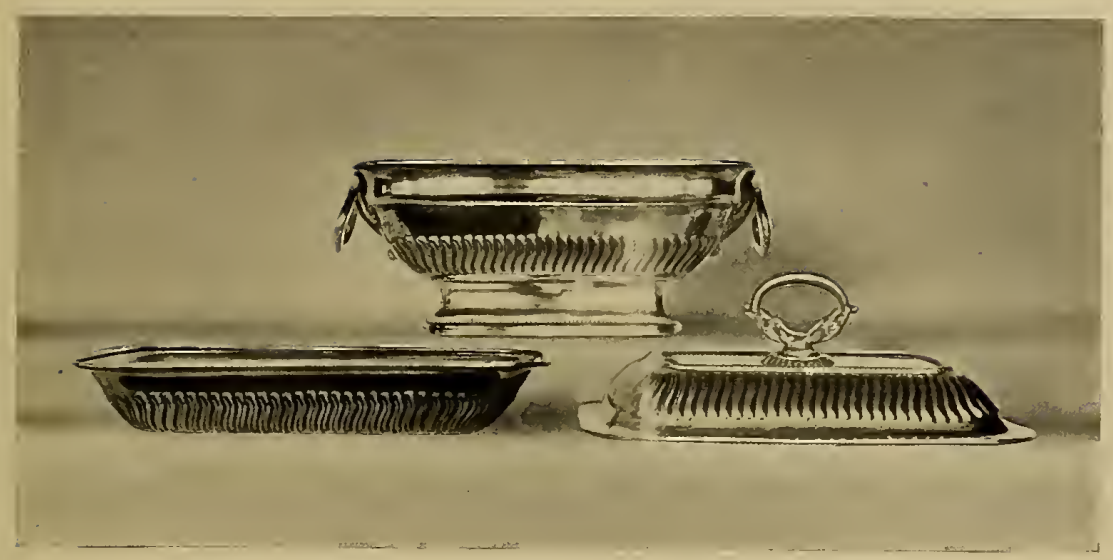

FLUTED TUREEN IVITH DISH AND COVER TO MATCH (I820)

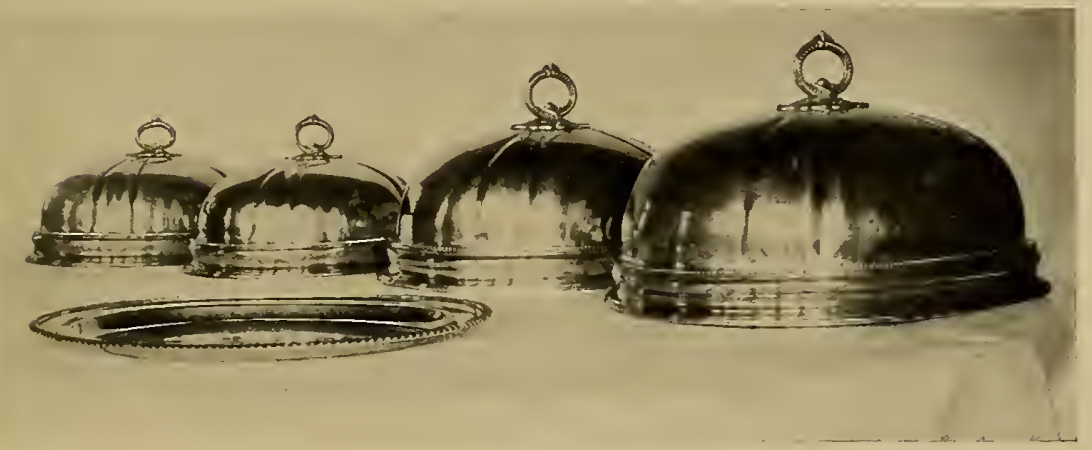

SET OF FOUR FLUTED DISH-COVERS WITH LARGE BEAD MOUNTS (I8IO) (Marked. See Plate LII)

MEAT DISH WITH GADROON MOUNT (I8I5) 



\section{XIV}

MAKERS AND THEIR MARKS

NE of the features which make the collecting of old English silver so attractive is the hall-mark indicating the date and place of manufacture, with the initials of the maker. Unfortunately there was no such system for the marking of Sheffield Plate, though occasional specimens are found bearing stamped marks put on by the manufacturer, and these have been the objects of much curiosity and conjecture.

It was known that the Sheffield Assay Office possessed a register recording the marks of many firms, but until this list was published in 1908 , no information of an official character was available, and collectors were obliged to content themselves with what knowledge could be gleaned from the objects themselves, and some known facts regarding certain firms. Now that the contents of the register have been made public, and Mr. Bradbury has collected as much information as possible concerning the history of the various manufacturers, our knowledge of makers and their marks is probably as complete as it ever will be.

Thomas Boulsover is not known to have used any mark on his wares, but pieces made by Joseph Hancock have been found stamped with his full name or with the initials I.H. 
Thomas Law, who like Boulsover and Hancock was originally a cutler, is the first of the early makers whose marked pieces are not infrequently met with. His mark was put on in such a way as to imitate the hall-mark on silver goods, the " $\mathcal{L} \mathcal{L}$." being several times repeated.

Other makers stamped scrolls resembling hall-marks so extensively on plated ware in the early days of the manufacture that the silversmiths complained greatly of the deception, and when in $\mathbf{I 7 7 3}$ an act of Parliament provided for the establishment of assay offices for the hall-marking of silver goods in Sheffield and Birmingham, a clause was inserted imposing a penalty of $£$ Ioo on the maker or dealer who should strike any letter or letters on goods plated to look like silver.

As a result of this act the platers put no marks at all on their goods, till in 1784 a new act made it permissible (not compulsory) for any maker in Sheffield or within a radius of roo miles thereof to strike his name and device in one punch upon plated goods, provided the same had been approved and registered by the guardians of the Sheffield Assay Office. As Birmingham was in the prescribed radius it was necessary for Birmingham manufacturers to register their marks in Sheffield, which was not at all to their liking, and many of them paid heavy penalties for using marks which they never registered. However, there were entered on the Sheffield register between 1784 and 1836 marks belonging to seventy-six manufacturers in Birmingham and fifty-one in Sheffield. The marks containing both name and device were necessarily clumsy, and in many cases would disfigure the article. This is probably one reason why the punches were so little used. 


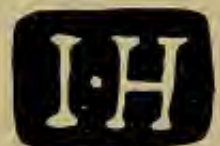

\section{IOSH HANCOCK} SHEFFIELD
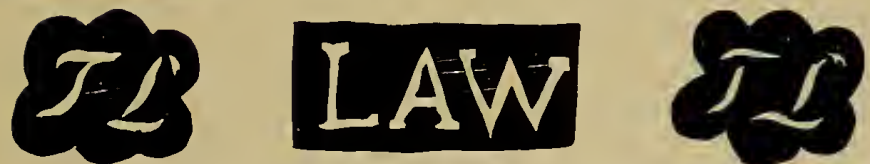

Thomas Law \& Co. Sheffield

From tankard shown in Plate XIII

Imitation Hall-Marks Unidentified
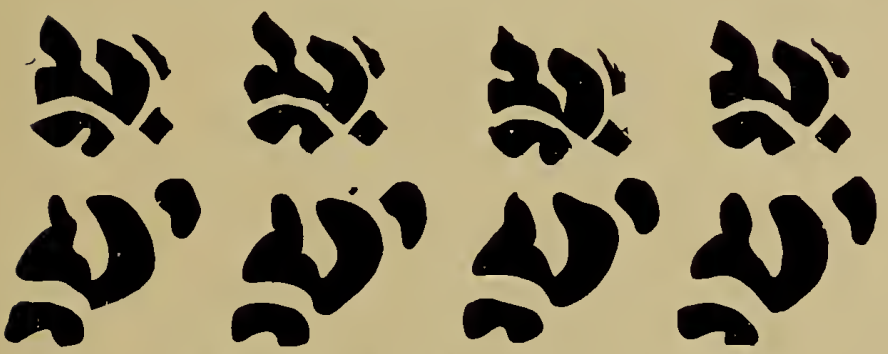

From two-handled cups shown in Plate XIII
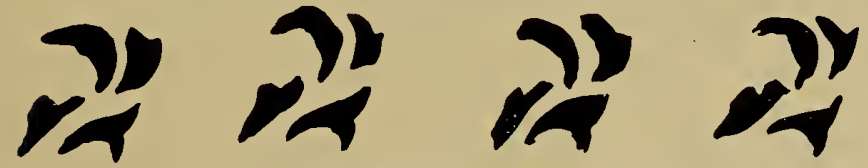

From coffee-pot shown in Plate XXXVIII
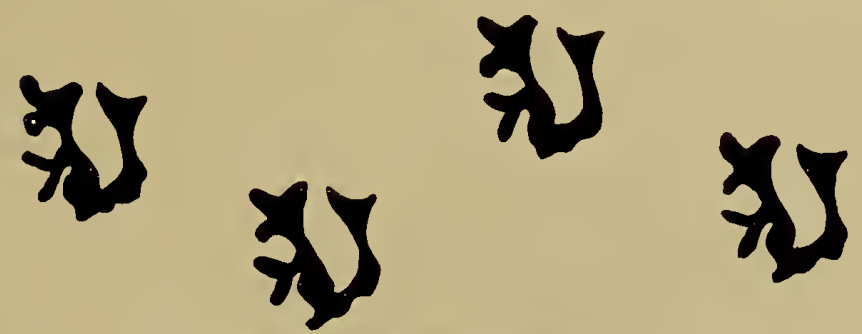

From salt-cellars shown in Plate LXIII
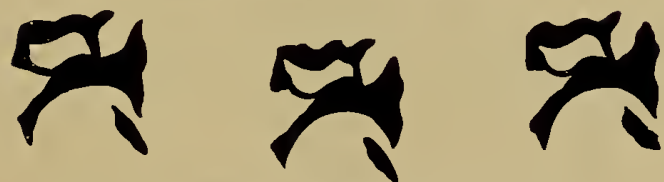

From fluted sweet-dish shown in Plate LXII 
Plate L

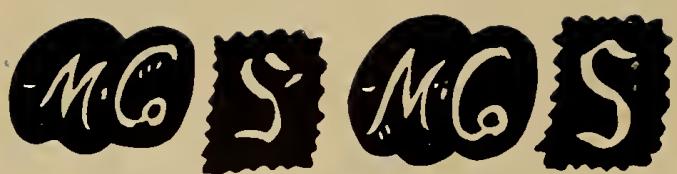

Richard Morton. Sheffield

This mark may be seen on an early coffee-pot in the Metropolitan Museum, New York

SOME MARKS USED AFTER I 784

These marks may be found in the Sheffield Register

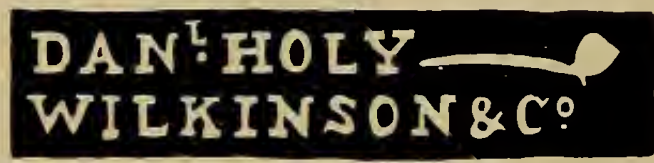

Daniel Holy, Wilkinson \& Co. Sheffield

Registered September, I784

From tankard shown in Plate XII

\section{SM I T H \& C?}

N. Smith \& Co. Sheffield

Registered September, 1784

Also by George Smith, Tate, Willm Nicholson \& Hoult, I8Io
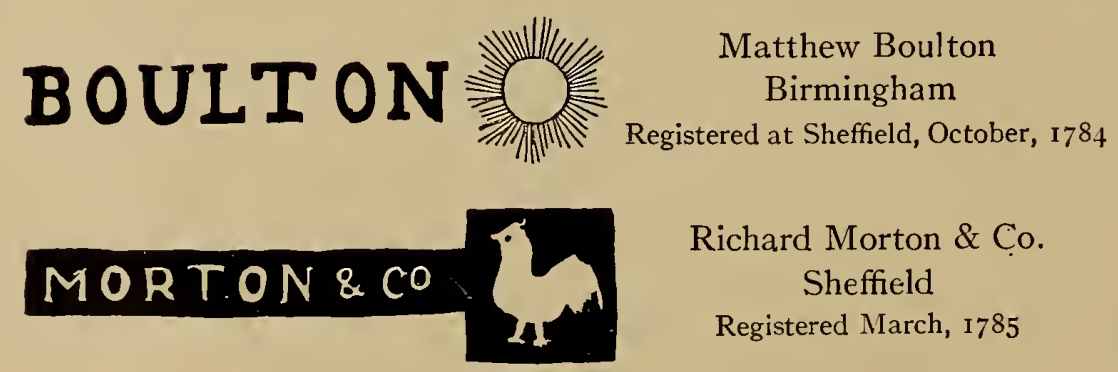

Richard Morton \& Co.

Shefficld

Registered March, I785

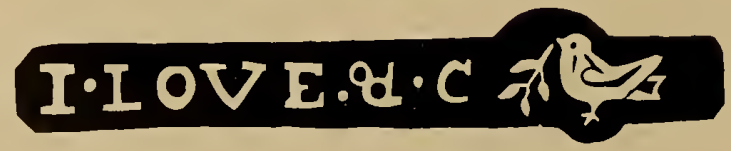

John Love \& Co. Sheffield

Registered March, I785 


\section{DAN:FOLY WILKINSON\&C?}

This mark, taken from a tankard shown in Plate $\mathrm{XII}$, is just as it appears in the register and was probably stamped at about that time. Later on, although it was illegal to punch the device without the maker's name, the law was not very strictly enforced and the device is far more frequently found alone.

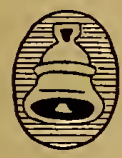

On the articles illustrated in Plates XXXIII, LVII, and LVIII, we have the bell mark which appears in the register in 1785 as

This Roberts was the Samuel Roberts who invented so

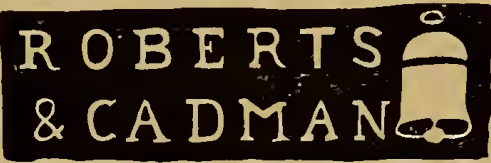
many ingenious devices for improvements in the process. An artist and a writer, he also possessed great inventive genius added to the qualities of a very able business man and a prominent citizen. He probably did more for the Sheffield-plating industry than any other maker. The firm of Roberts \& Cadman became Roberts, Smith \& Co., then Smith, Sissons \& Co., and finally W. \& G. Sissons, under which name it now manufactures electro-plated goods and stamps them with the same bell.

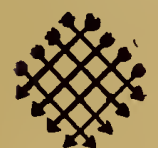

The mark of the crossed arrows found on the soup-tureen (Plate XXXIII) is another instance of an old mark that is still in

tered in $I 8 I I$ as goods of fine CRESWICKS I850, but their dies were finally use. It was regisThis firm made quality as late as sold, and some of them are now in possession of other Sheffield firms. The mark is now used by W. Hutton \& Sons on electroplated and white metal goods. 
A close rival to Samuel Roberts was Matthew Boulton, who founded the famous Soho factory in Birmingham. He endeavored by the excellent quality of his goods to remove the "Brummagem" stigma from his native town, and so far as the plating industry is concerned he succeeded. His mark, the sun usually stamped twice, is perhaps the one most frequently met with, and it is always found on pieces of excellent design and workmanship. It is said that Boulton was in the habit of sending a file with his goods in order that his customers might test the quality of the plate.

Although the majority of fine pieces of Sheffield Plate are unmarked, a maker's name always conveys an added interest, and the marked pieces are well worth looking for.

I have included in the following lists a few of the marks not on pieces in our collection, which are most frequently met with. All these marks are much enlarged. 


\section{ROBERTS \& CA DMANeo}

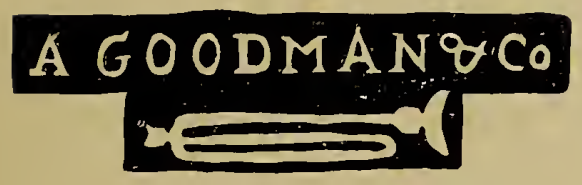

Roberts \& Cadman. Sheffield Registered July, I785

Alexr. Goodman \& Co. Sheffield

Registered July, I 800 From candlestick shown in Plate XXVII

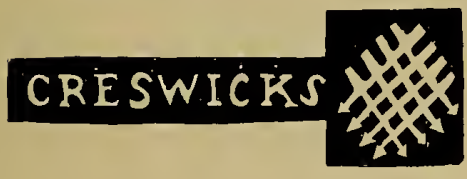

Thos. and James Creswick Sheffield

Registered July, I8II

John Turton. Birmingham

Registered September, I 820

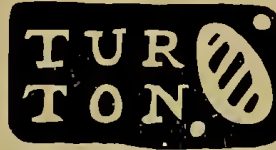

Registered September, 1820

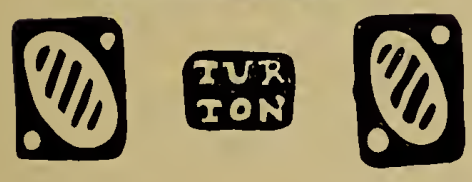

\section{HY WI LK INSON\&C?}

Henry Wilkinson \& Co. Sheffield

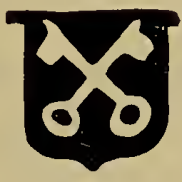

Registered January, I 836

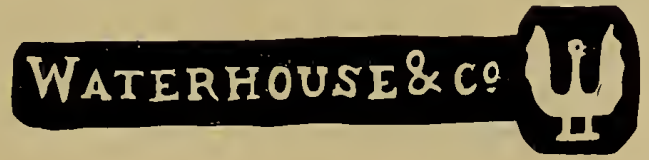

$\{$ John Waterhouse. Sheffield

$\{$ Edward Hatfield \& Co. Sheffield

Registered June, 1836 


\section{A FEW MISCELLANEOUS MARKS}

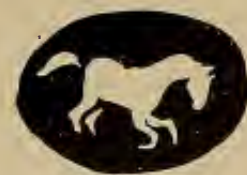

From one of the sugar-tongs shown in Plate IX

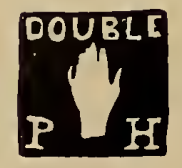

A French Mark

Taken from round candlesticks shown in Plate LXII
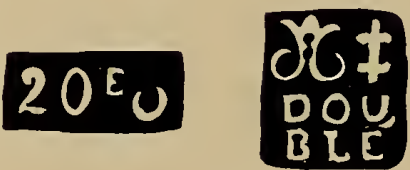

French Marks from coffee-pot shown in Plate LIX

From ewer shown in Plate LXV

Walker Knowles \& Co.

Sheffield

From dish-covers shown in Plate XIVIII

Russian Mark

Taken from cream-jug shown in Plate LIX 


\section{Plate LiII}

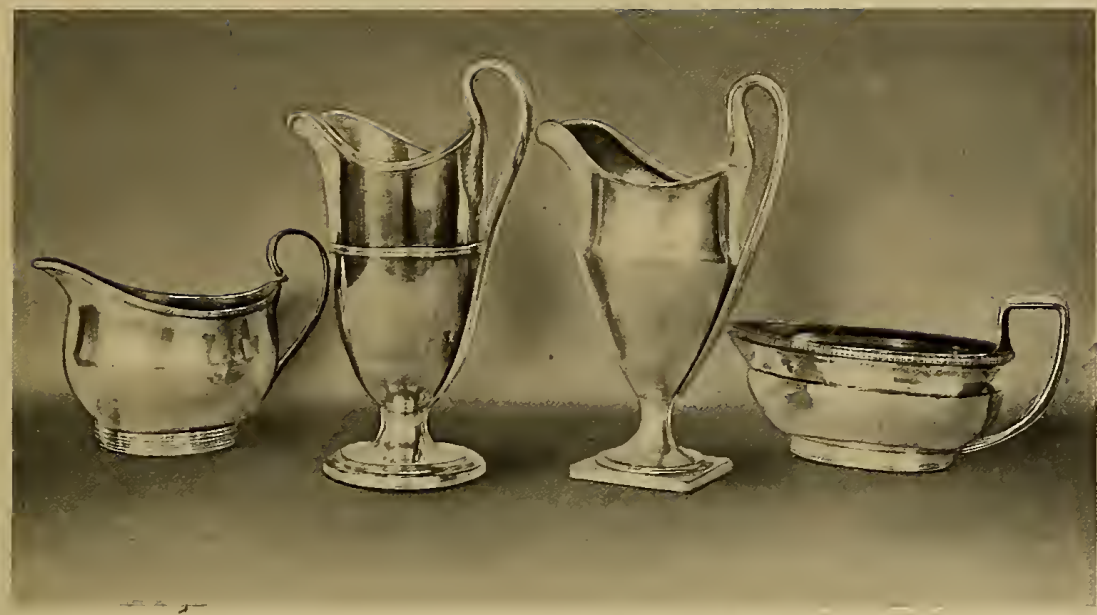

CREAM-JUG WITH SILVER THREAD EDGE (I800) DITTO (HELMET-SHAPED) (I790)

DITTO WITH SILVER ENGRAVED MOUNTS (I795) CREAM-JUG WITH SILVER GADROON MOUNTS (I800)

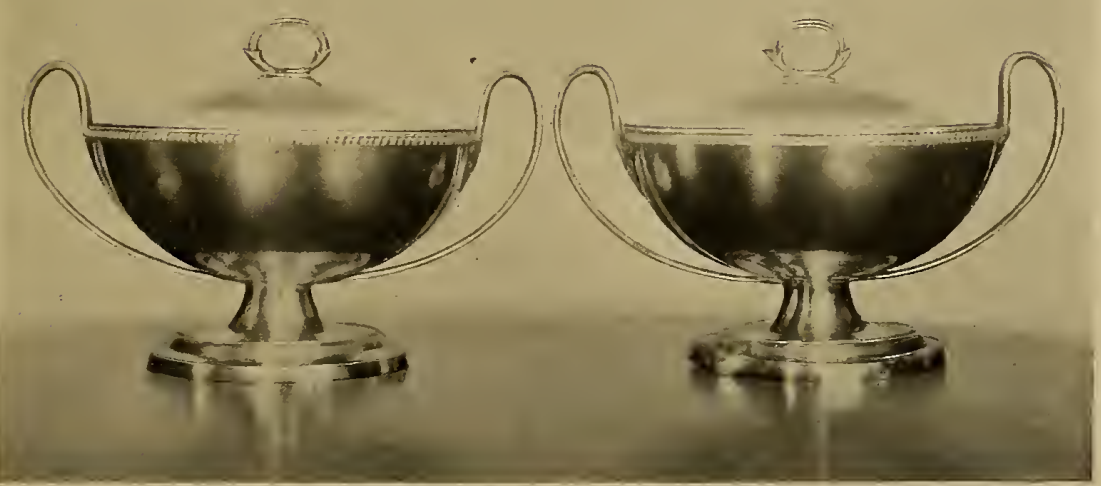

PAIR OF SAUCE-BOATS WITH GADROON MOUNTS (I790)

Such pieces as the above are favorite models for the fakers 



\section{XV}

\section{REPRODUCTIONS AND FAKES}

INCE Sheffield Plate has come to be more widely appreciated, some interest has been shown in an effort to revive the old industry, and as I have already stated, a number of very creditable reproductions have been produced by the old method.

These are all in the styles belonging to the later period when the body of the tray or dish was made from the sheet of rolled plate, and the ornamental edges and mounts struck from silver by means of dies, then filled and fixed with soft solder. Modern workmen, however, find the process so difficult that the saving in the value of the metal, now comparatively cheap, is nearly balanced by the extra cost of manufacture, so that the selling price of these reproductions is very little less than that of modern silver or of genuine old plated ware.

From this it is evident that from a commercial standpoint the old process has lost its raison d'être, for it is obviously absurd to imitate an imitation at approximately the cost of the genuine article, and purchasers who can afford old Sheffield Plate or reproductions in modern silver would be unwise in paying equally high prices for modern plated ware. 
Moreover manufacturers say that it is impossible to find workmen nowadays who are sufficiently skilful to copy by the old method the finer and more delicate designs of the eighteenth century, so that true reproductions of the more beautiful and interesting pieces are out of the question anyway, though they can be copied fairly well in silver.

I therefore conclude that while a few people might have a sentimental interest in the revival of this discontinued industry, the making of Sheffield Plate has become to all intents and purposes a lost art, and it is not probable that there will ever be any demand for what might be called "genuine reproductions."

Of the so-called reproductions which now flood both the English and American markets, it is quite a different story. They are cheap, at least to the producer, and herein lies one unfortunate reason for their popularity. As to quality, they may be good, bad or indifferent, but the bad predominate. As regards design, these goods are turned out so hastily that it would not pay the makers (who know their uncritical public) to copy the old patterns closely and carefully. So long as they get something sufficiently resembling the original to be labelled "Queen Anne," which generally means anything with flutes on it, or "Georgian," which of ten means nothing at all, they have their market and their profit. In the matter of workmanship it is also true that very little is demanded. The parts may be cast or stamped in copper, carelessly put together, and the whole article placed in the electric bath where a more or less thin coating of silver covers all defects.

Reproductions made in this way may be good, and still much cheaper than silver, if the design is faithfully copied, 


\section{Plate LiV}

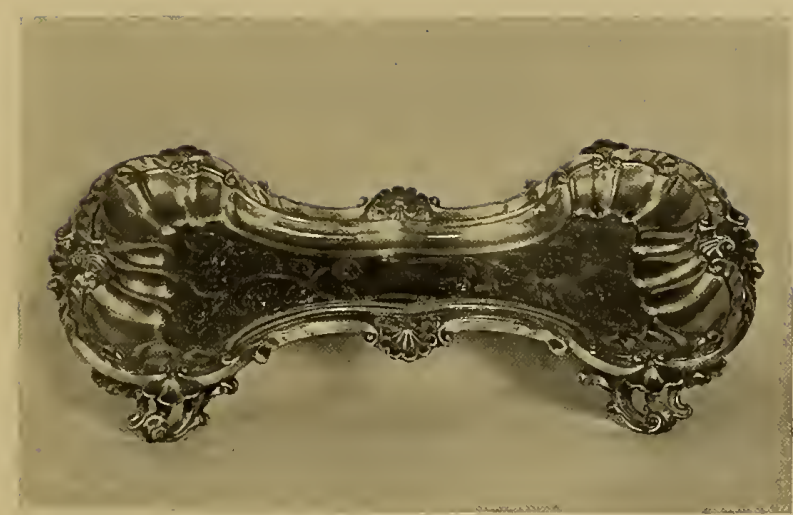

SHAPED SNUFFER-TRAY ON PIERCED FEET (I833)

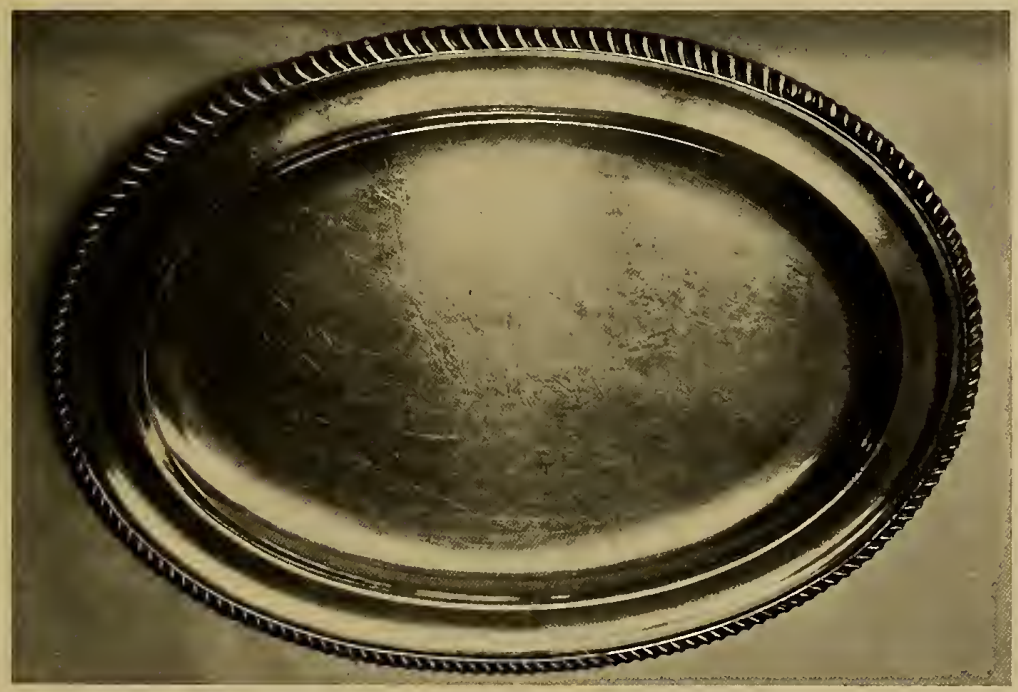

MEAT DISH WITH GADROON MOUNT (I8I5)

Articles like this and the above could be reproduced to-day by the old method 



\section{REPRODUCTIONS AND FAKES}

the parts well made and put together, and the silver plating as heavy as practicable. They are legitimate reproductions when made and sold as such, but when their whole outward appearance is contrived with the intent to deceive the purchaser, and he is allowed to believe them to be genuine Sheffield Plate, they are fakes.

The majority of fakes are cheap electro-plate, always on copper. To realize the full significance of this latter point it is only necessary to stand before any shop window filled with these wares, which always have a few conspicuous scratches to show the foundation metal, and hear the passersby reverently murmur "on copper." One almost expects to see them remove their hats. Frequently fakes are not lacking in wire edges, and other supposed indications of genuineness, but their general clumsiness in design brands most of them so conspicuously that the experienced collector recognizes them at a distance. They are only intended to deceive the people who for some reason which they don't try to fathom have a vague notion that Sheffield Plate is a desirable thing and who rely implicitly on the magic label. The extraordinarily large supply of these goods is a proof of the demand, and is not flattering either to the taste or the intelligence of the public.

However, there are fakes and fakes, and they are by no means confined to the class of article that deceives only the most ignorant. The following incident illustrates what generally happens once to the most careful collector, as well as daily to tourists and general curio-hunters. It occurred in the early days of our collecting, but not before we had read all the then available literature on the subject, and gained some knowledge by studying good specimens. 
A friend rang us up by telephone to say that he had found some wonderful old Sheffield Plate in a suburban shop kept by a delightfully unsuspecting old woman. He had bought a set of candlesticks and a magnificent tea-tray, but was obliged to leave behind a tempting bread-basket which he had asked the old woman to hold in reserve till his friends (meaning my husband and myself) arrived.

We had read that these bread-baskets were rare and had never seen one. The woman told a pathetic tale of an old lady who, after keeping these heirlooms in green baize bags for many years, was now in dire distress and forced to part with them. She, the innocent shopkeeper, said she knew nothing of Sheffield Plate, but having known the owner for many years, could vouch for their history "in the one family." The design of the basket was certainly good and the mounts well finished. It bore all the marks of rightness then known to us, and the green baize accounted for its new condition; so being somewhat off our guard we purchased it at a good price.

On passing another small shop a few weeks later, what was my horror to see an exact duplicate of our precious breadbasket in the window - and further still another! (They were getting ready for the American tourist season.) It then behooved us to examine our purchase with the degree of critical scrutiny that should have saved us from the blunder in the first place. We asked ourselves the important question, "How was this made?" and found on close examination that we had the usual fake rather more artfully contrived and carefully made than any we had seen before. It was years before we found the genuine specimen shown in the opposite illustration. 


\section{Plate LV}

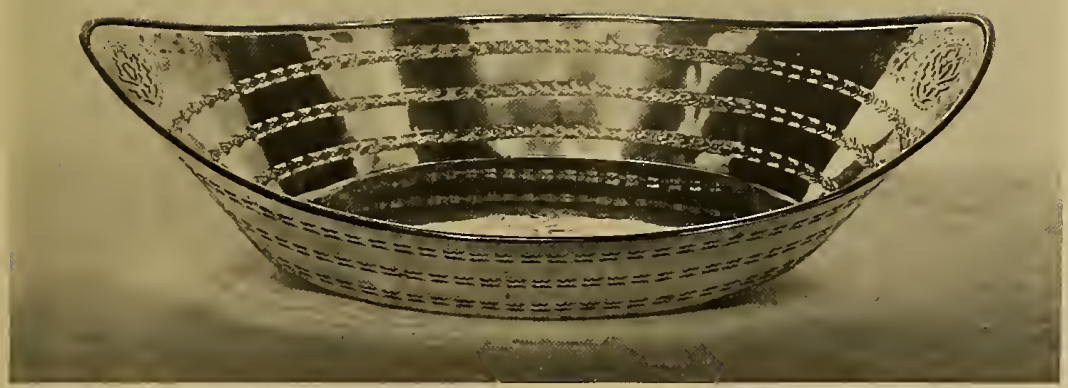

PIERCED AND CHASED BREAD-BASKET (I790) By' Richard Morton 

More subtle than the best of the electro-plated fakes are the synthetic ones that are intended to deceive the wary, and many are the devices resorted to with telling effect. Every dealer who has many pieces of genuine old plate passing through his hands comes across old dish-covers, hopelessly broken coffee-pots, portions of candlesticks and the like, and somewhere in his workshop is a box of odd handles, mounts, feet, etc., that have been rejected from articles that he has repaired. These things continually challenge his ingenuity to devise some way of turning them to account, and he is seldom found wanting. For instance, an odd salt-cellar with blue glass liner has lost its feet. With a cover made from an old coffee-pot lid, or even from a piece of dish-cover, it only wants a bit of reeded wire for a handle to become an easily salable mustard-pot. I have seen a synthetic fake made from eight or ten odd bits of candlesticks and other broken articles, all "genuine Sheffield Plate." The finished product of ten bears little resemblance to any old piece, but it can be sold as such (and guaranteed) to any one not familiar with orthodox designs. An old dinner plate, for instance, is not very unlike the top of the little tray shown in the following Plate. The reader can readily imagine such a plate transformed into a salver by the simple addition of three feet from an old salt-cellar. Old copper and brass tea-urns are sometimes electro-plated and sold as Sheffield Plate.

There are all gradations between such made-up articles, sometimes done to the order of the customer, who in this case is not deceived, and simple cases where an otherwise good specimen has had a small missing portion supplied from another broken piece, and it is for the collector to draw his 
own dividing line between legitimate repairs and ingenious patching up.

In the case of straightforward repairs, it is very rarely that a missing portion can be replaced by exactly the right thing in old plated ware, and the best workmen replace any worn-out part by a new silver one as nearly like the original as possible with no attempt at concealing the fact. An article repaired in this way is as good for practical use as it ever was, though frankly not in its original and perfect state.

The question is frequently asked why re-plated specimens are not prized by collectors, and I have before me a reply in a book dealing with this subject, that it is "because the process has been covered up." I am sure that many people believe that it is because the copper has been covered up. It was never intended that there should be any outward evidence either of copper or of the process by which the article was made. On the contrary, it was owing to the fact that the copper had revealed itself, thereby showing that the article was only plated ware, that many old family pieces were sent to be "done up" after electro-plating had become popular. There is no question that many fine old specimens were thereby given a longer lease of life, and although the matter calls for discrimination, it cannot fairly be disposed of by saying that re-plated pieces are of no interest.

Let us consider the result of re-plating in a typical case like that of the late period silver-mounted candlestick. (Plate LVII.) The silver is practically gone, leaving an article of copper and the soft leady substance with which the thin silver mounts were filled. This filling still preserves the original form of the silver stampings, and the stick might be fairly presentable with a new plating of silver, if it 
Plate LVI

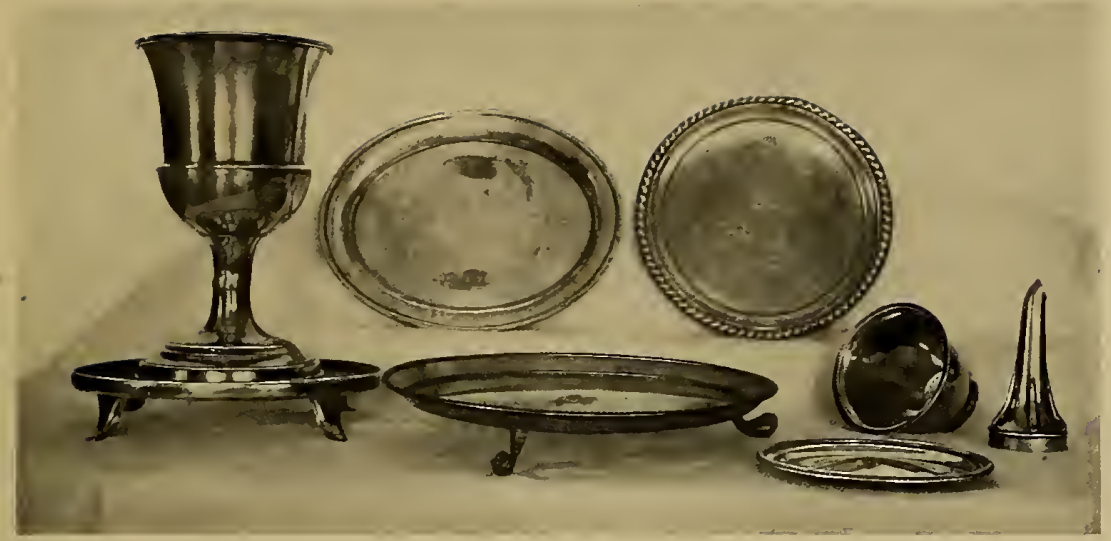

GOBLET (I785) TEAPOT-STAND (I795) OVAL TRAY IVITHOUT FEET (I800) ROUND TRAY WITH EDGES RAISED TO FORM GADROON BORDER ( $77_{5}$ ) ROUND TEAPOT-STAND WITH CLAIV-AND-BALL FEET (1785)

WINE-STRAINER IN TIVO SECTIONS (I800) STAND FOR SAME (I800)

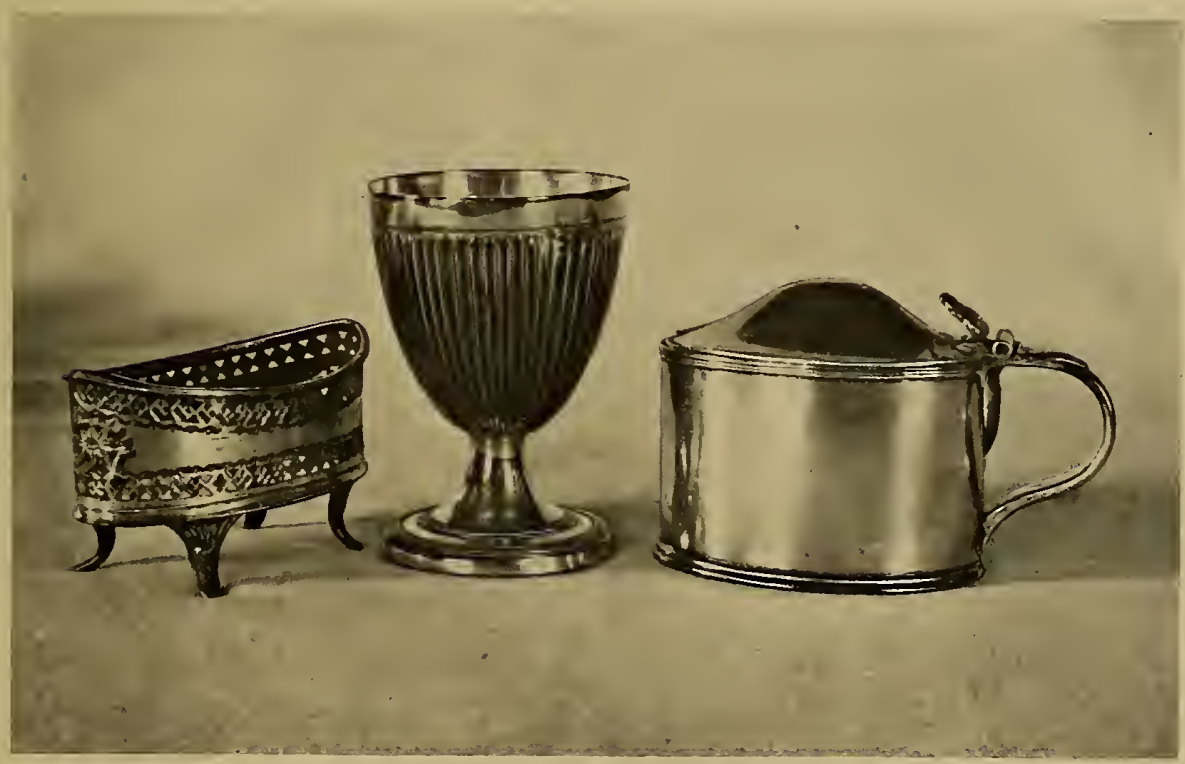

PIERCED AND CHASED SALT-CELLAR ( 1785 )

SMALL FLUTED GOBLET (I790)

OVAL MUSTARD-POT WITH THREAD MOUNTS (I790) 

could be done. Therein lies the difficulty, for only the thinnest coating of silver can be made to adhere to the leaden filling, and moreover when placed in the electric bath its surface becomes covered with tiny holes. Therefore in the case where a piece of this description has become worn "down to the lead," it is waste of time and money to replate it, for the result cannot be satisfactory either as to wear or appearance. When too unsightly for further use such pieces must be considered past hope, but in these days, when modern reproductions are guaranteed to last five years, we cannot find much fault when an article becomes worn out after it has stood the wear of the best part of a century.

On the other hand, pieces that were made, as all the earlier ones were made, entirely of rolled plate become simply copper articles when the silver is worn or dissolved off. Such a piece is then in the condition of a reproduction in copper ready to be plated, but it is correct in design and skilfully made. A piece of this character may be electro-plated, and is not to be despised. Of course it will lack the surface condition which is so attractive in old silver and plated ware, but in this respect it will improve with time, and the beauty of form and workmanship will be preserved in a well made and fairly durable article. In fact many fine old pieces were re-plated so long ago that with constant use they have acquired a surface very like the original, and they seem to me far more desirable than pieces of poorer quality or design in original condition. The small articles represented in the next group might well be re-plated when necessary.

I might remark here that about I 830 there was a quantity of Sheffield Plate made that was as ugly as it was genuine, and much of it was very thinly plated. 
There is another process besides replating, by which specimens that have become somewhat shabby are made more salable, and here again the purchaser must draw his own distinction between what may be called legitimate repair and faking. Personally $I$ should draw the line short of any touching up whatever, for it seems to me that a piece that cannot stand on its merits is not worth considering. The process known in the trade as "ragging" consists in depositing, usually by means of an electric current, a thin film of silver on the spots where the copper is most exposed. Naturally this soon wears off, to the sorrow of the purchaser who has paid for an article in a better state of preservation.

To sum up the matter of fakes, the producers of these have so well profited by what has already been written about "tests of genuineness" that it is now impossible to state in writing any rules by which persons unfamiliar with the originals may identify them. It is a matter of experience and close observation, where the study of a few fine specimens will always bring its reward. For the benefit of any beginner who may wish to examine critically one or more pieces, and does n't know how to begin, I repeat a few important statements:-

(I) Old Sheffield Plate was usually, but not always, on copper.

(2) It was made from a flat sheet of metal already plated on one or both sides. It is generally possible to see whether the article was made in one piece or in several parts; whether each part was hand-raised or diestruck; also how and where the parts were joined. If there is no evidence of how the piece was constructed, it is safe to conclude that the plating was done after 


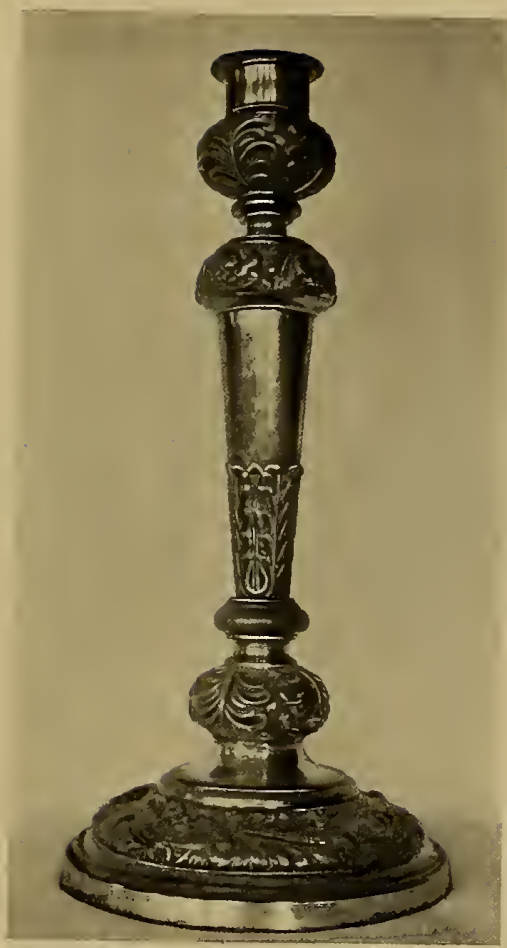

Plate LViI

ORNATE CANDLESTICK WITH FILLED MOUNTS (I830)

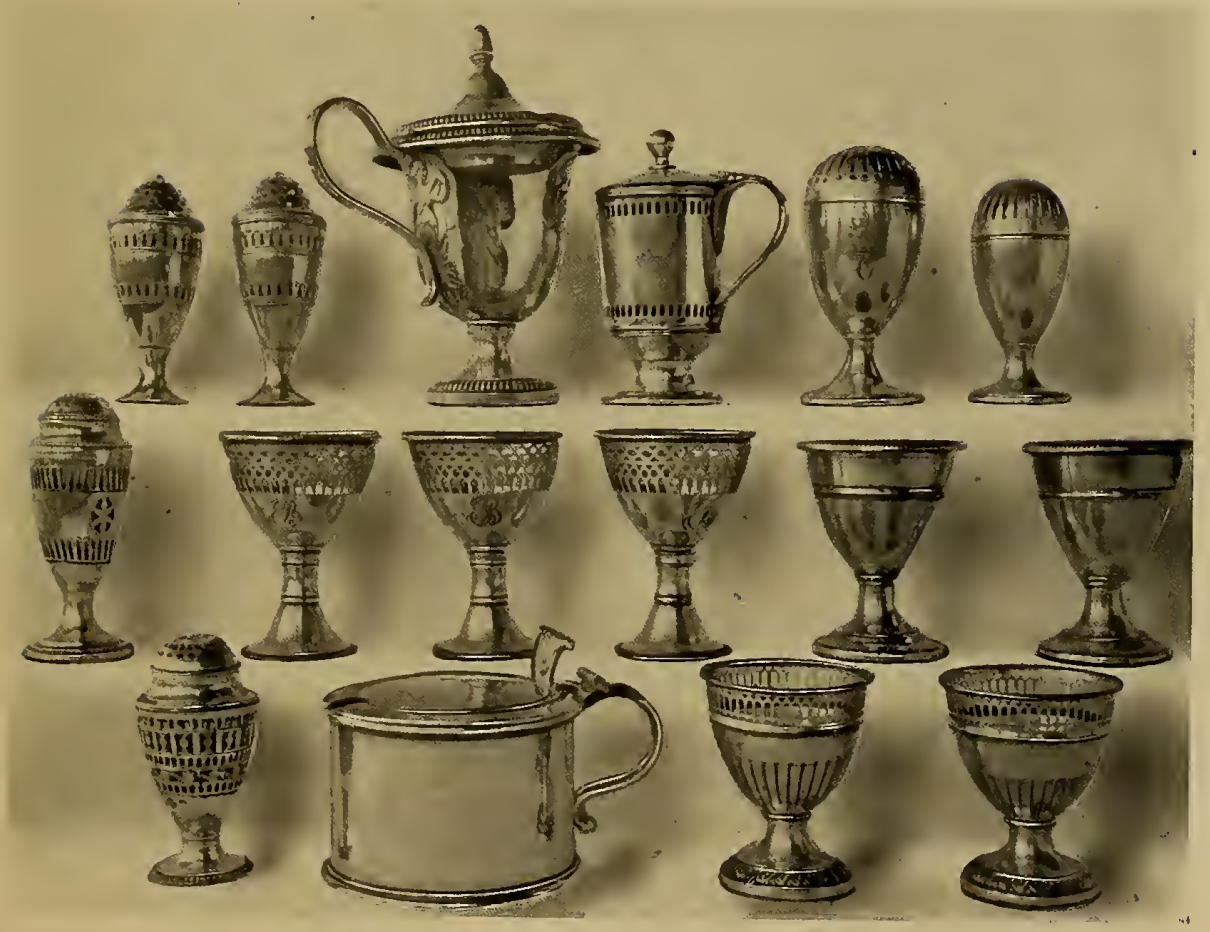

GROUP OF MUFFINEERS, MUSTARD-POTS AND EGG-CUPS (I780-1800) 



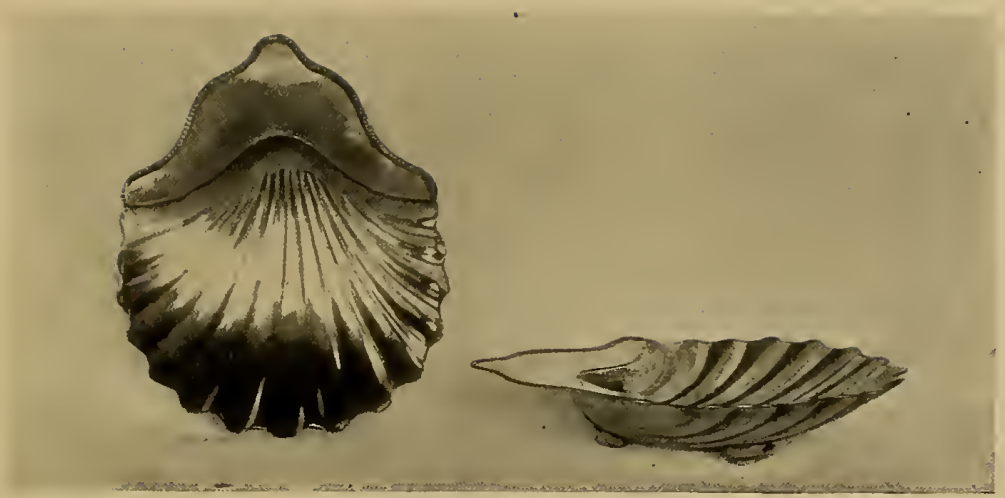

PAIR OF SCALLOP SHELLS (I775)

Where these shells have become worn on the angles the plate is seen to be very thick

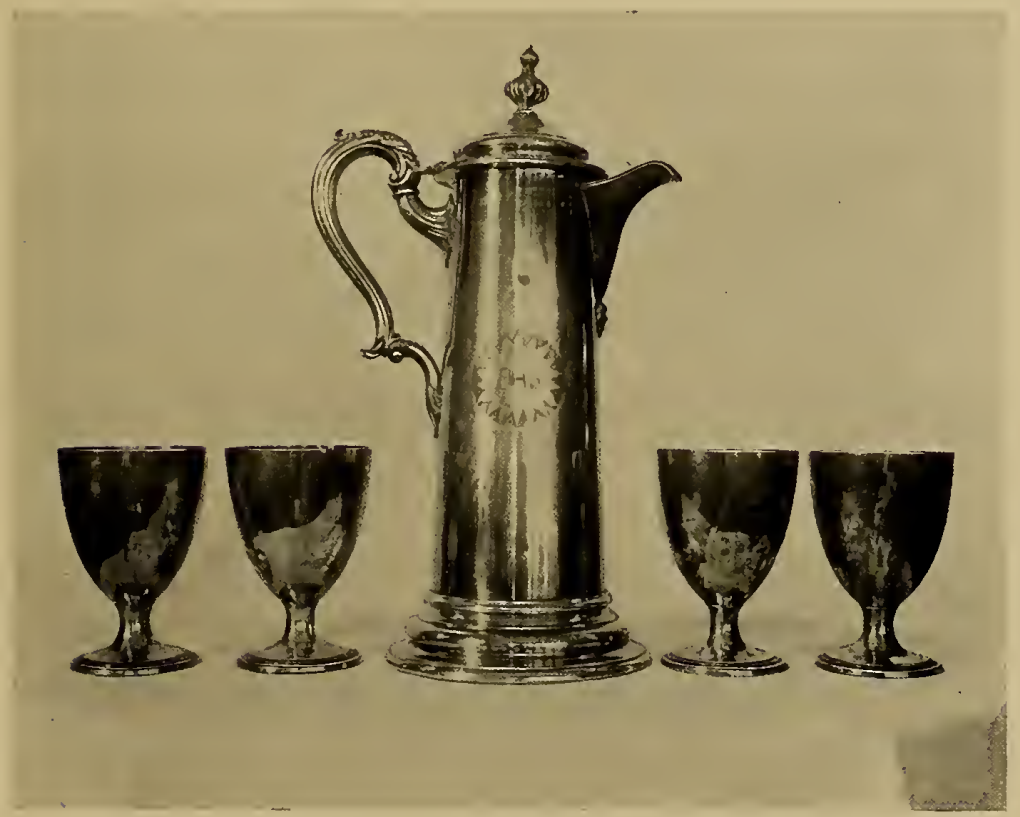

COMMUNION FLAGON (I800). (Marked with bell. See page 67) SET OF FOUR GOBLETS, TARNISHED TO SHOW DOVE-TAILED SEAMS (I800) 

it was put together, and that the article is either a modern copy or an old one that has been re-plated.

(3) On pieces of good quality the silver was of very perceptible thickness, and will still be so in unexposed parts if not all over.

(4) There was sometimes a silver shield (which it is not difficult to fake).

(5) Some pieces are marked with the name or device of the maker.

(6) The color is the same as that of solid silver goods or coin metal (containing alloy), and not white like the virgin silver deposit on modern plated goods.

(7) File marks should be wanting on genuine pieces.

(8) The designs were those of the silverware of the period.

It would require too much space to correct all of the mis-statements in the small amount of American literature that I have found on the subject, but a few of them are too hopelessly misleading to be overlooked. They all refer to simple matters of fact which can easily be verified by any one who will take the trouble, and it does seem a pity that American writers should cumber literature and confuse their readers with such statements when correct information may so easily be obtained. The following are direct quotations:-

"The copper body is always one of the sure tests." (It is to be hoped that no comment is necessary.)

"All genuine Sheffield Plate is finished by one of these methods at the edges." This statement refers to silver edges and silver mounts, the first of which was introduced in I784, after Sheffield Plate had been made for forty years! 
"Pieces with solid silver mounts are worth more than those with filled mounts." The silver mounts were always hollow stampings, and always filled.

"Makers' marks, when found, prove British manufacture; Continental imitations never bear such marks." What about French plated ware, which after I795 was required by law to bear the words "Doublé" or "Placqué" as well as the device or name of the maker? Sheffield Plate made in Holland is said to be always unmarked, but many pieces made in Russia and Austria have been identified by the marks of the makers.

With the naive remark that "In England the term most frequently applied to this plated ware is "close plate," "I have already dealt.

It is partly to such statements that we Americans owe our unfortunate reputation abroad for ignorance and gullibility.

For further technical explanations of all essential matters referring to the subject I refer the reader to Mr. Bradbury's "History of Old Sheffield Plate," an accurate and enthusiastic work which should be in every reference library.

Let any one who wishes to add to his possessions good specimens of Sheffield Plate first use every means at his command in the way of literature, museum collections, and his own genuine pieces if he has any, to study the subject till he knows what to look for and how to recognize it when he finds it. Let him remember that the selling of antiques is not, any more than any other business, conducted for purposes of philanthropy, and that the dealer who goes out of his way to instruct his customer is doing much more than the law requires. Those who know their business, however, appreciate the best; and our experience is that they talse 


\section{Plate LiX}

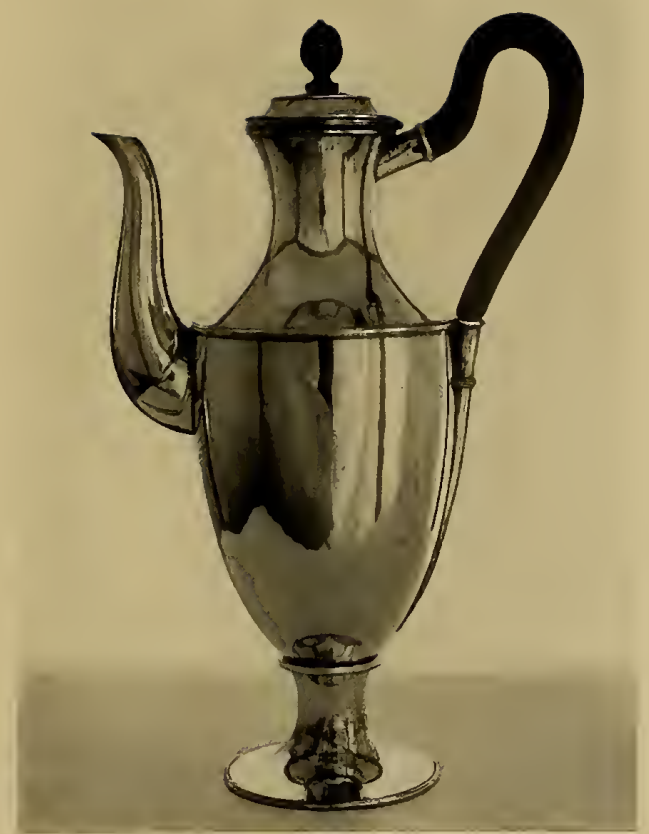

FRENCH COFFEE-POT. (Marked. See Plate LII)

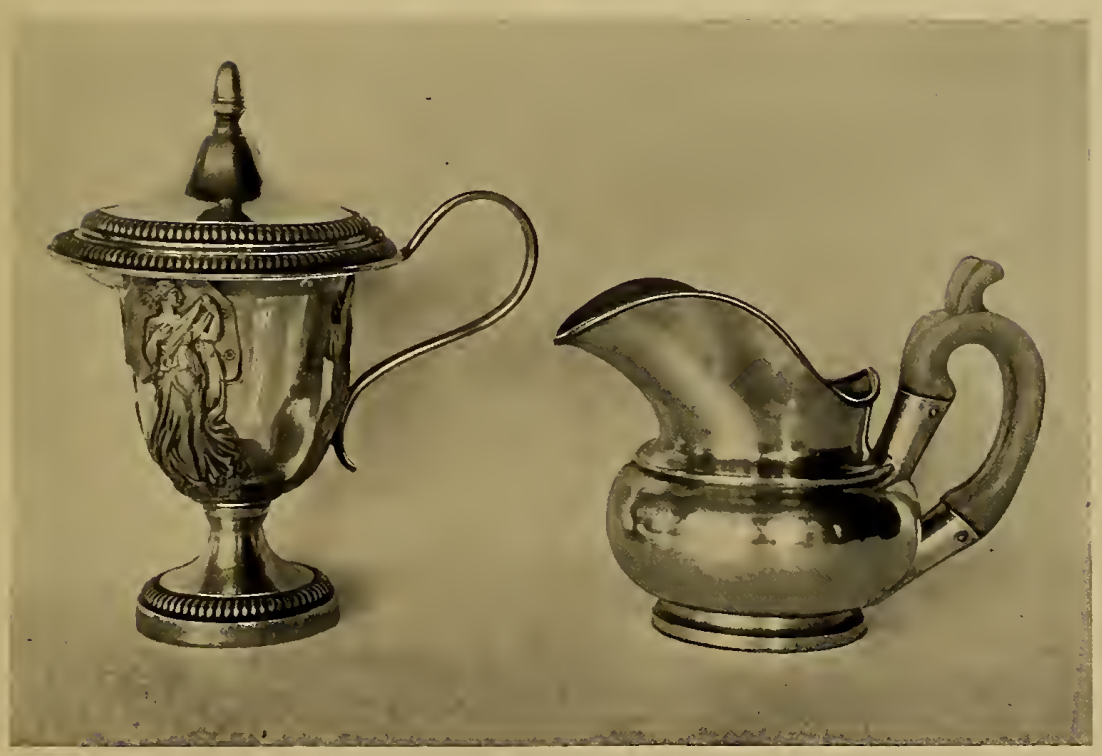

FRENCH MUSTARD-POT (about I800)

The Maker's Mark is partially obliterated. The Mark $20 \mathrm{M}$ refers to the quality of the plate RUSSIAN CREAM-JUG WITH IVORY HANDLE (I830). (See Mark, Plate LII) 

great pleasure in showing their best goods to customers who care for them, and that they are proud of themselves if they sell, and of the customer if he buys, a really fine piece.

I am sure that all dealers prefer to sell genuine goods, but the demand is so much greater for cheap imitations that honest dealers have often to depend on these for their profits, and it is for this reason that so many of them sell reproductions (as such) together with the genuine goods. Of course the bargain hunter who pits his knowledge against that of the small shop-keeper usually gets his just reward. He must be wise indeed to play successfully at a game where his opponent always has the advantage, and he deserves little sympathy if in his attempt to get something for nothing he gets "done" himself. Moreover, so long as a host of ignorant and indiscriminating buyers clamor for cheap antiques merely for the name, the trade of the faker will flourish; and who can blame him for supplying the demand (which the public, and not he, have created) at a far greater profit than he could hope for by selling the "real stuff" to people who neither know nor appreciate it?

I have tried in this book to show enough of the beauty of the genuine to cause some of my readers to study and appreciate the old family plated ware in their possession, and to stimulate in any would-be collectors or purchasers a preference for a few really fine specimens of old Sheffield Plate rather than any quantity of fakes or reproductions, however good. 


\section{XVI}

WHERE OLD SHEFFIELD PLATE MAY BE BOUGHT - AND SOME HINTS ABOUT PRESENT VALUES

$\mathrm{N}$ the old days both silver and plated goods were pur1 chased through the old-fashioned local silversmiths or retail dealers, but large orders were usually filled by the manufacturer after the customer had made his selection from the illustrated catalogue. Now, of course, the buyer of the old plate must obtain it from one of the various sources where second-hand goods are offered.

There is far more Sheffeld Plate to be obtained in England than in the United States, not only because it was made there but because owing to custom a great many more second-hand articles of every kind come into the market. For instance, upon the death of a householder, it frequently happens that the whole contents of the house are sold at auction, and the money divided among the heirs, while in America the family possessions are themselves divided and handed down from one generation to another. In England the members of the family often "buy in" whatever each individual wishes to keep, but it is still true that household belongings, which in America would be sold only under the direst necessity, change hands many times over in the old country. That is one of the principal reasons why there are always more antiques for sale there. 


\section{Plate LX}

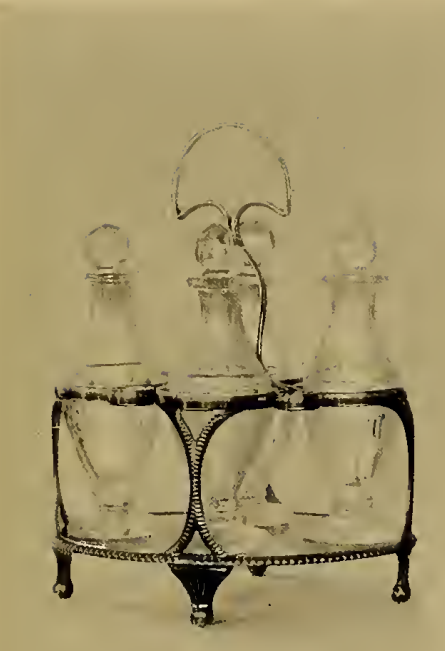

SOY-FRAME WITH CUT-GLASS
BOTTLES
$($ I 800$)$

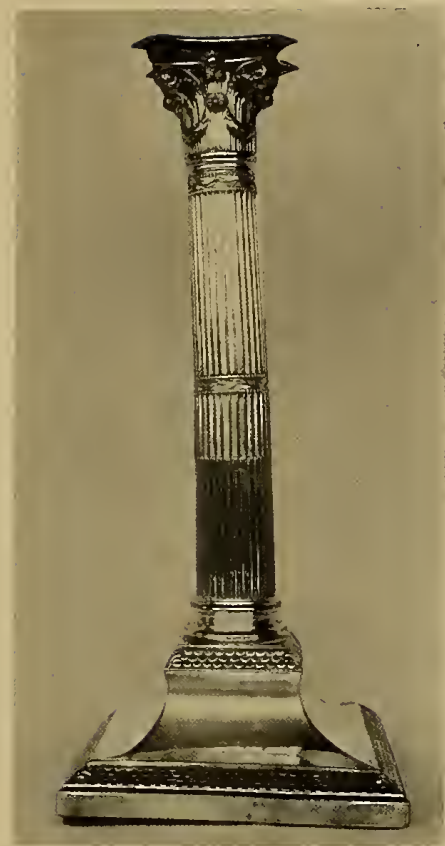

TWELVE-INCH CLASSIC CANDLESTICK (I 786)

The full-size drawing from which this candlestick was made appears in a catalogue in the possession of Messrs. T. Bradbury \& Sons, Sheffield

The catalogue price is $37 /$ -

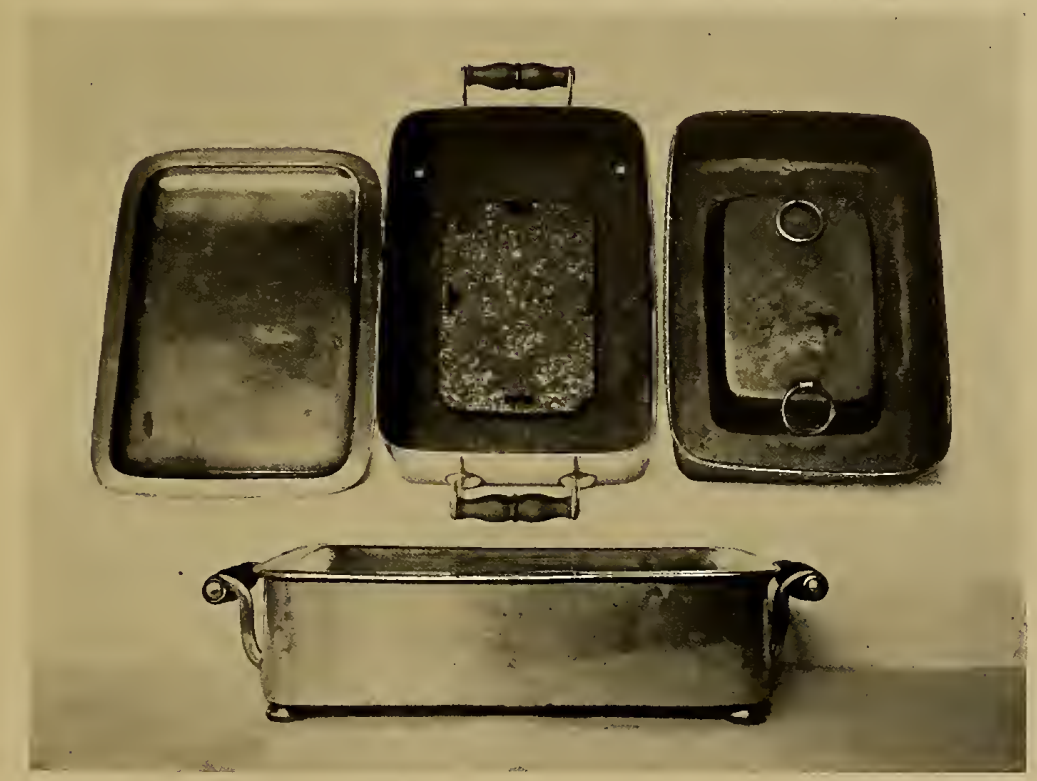

PAIR OF BREAKFAST DISHES WITH HEATERS (I800)

(To hold both iron heater and hot water)

All these articles were purchased in the London market 

Twenty years ago there were numerous happy huntinggrounds for bargain hunters who appreciated good antiques, and most wonderful finds were possible in out-of-the-way places. Perhaps the institution that in the past has proved the greatest bonanza to the knowing ones is the Caledonian Market in London. Now that the secret is out, and the place has become generally known as a magic treasurehouse, the spell is broken, but it still preserves something of its old character, and even now one may be lucky enough to pick up a good piece of old furniture, a rare print, or occasionally an interesting bit of Sheffield Plate.

The market is a vast stone-paved area, mostly uncovered, only a small portion of which is devoted to the sale of horses and cattle. The remainder is a general selling-place. At ten o'clock on a Friday morning the carts begin to arrive from all over London and the surrounding country, and a miscellaneous crowd of buyers and sellers comes pouring in while each hawker unloads his wares and displays them in his allotted space. It would be difficult to conceive of any sort of old junk not represented, from a superannuated piano to a much-pawned diamond ring. To find anything worth while one wants to be everywhere at once and see the goods unpacked, for many dealers (or their representatives) are there and the salable things are snapped up immediately.

It is thrilling indeed to scan rapidly the heterogeneous mass in the hope of finding some rare treasure before it is carried off by a rival. Too often nowadays, however, it is a vain search through dreary wastes of rubbish, for the humblest venders have at last become wise and know where to dispose at once of any articles of special value. They have also learned to gauge the ignorance of the wealthy bargain 
hunters who now arrive in their motor-cars and find their demands well catered to. While only rarely does one find a genuine piece of Sheffield Plate in the market, it would be easy to collect a cart-load of Brummagem wares on any Friday morning. Some of it is dirty and a bit battered, but the venders usually find it unnecessary to give their wares even a superficial appearance of age.

It is astonishing to watch the trade done by one of these hawkers, who simply stands over a glaring assemblage of tawdry productions and says "Yes" to the fine dames who innocently put the question, "Is this old"? and then after suitable haggling cheerfully pay half the price originally asked for a worthless article and go away well pleased. Verily they have their reward, but it is not in the form of art-treasures.

A visit to the market will generally be more productive of experience than of desirable acquisitions, but there are always entertainment and instruction for any one whose eyes are open, with an occasional chance of a substantial find. The kind of articles found in the market by connoisseurs are the things not generally sought after, or even recognized, by the multitude. The candlestick illustrated is of great interest to us because we have seen the exact design in an old Sheffield manufacturer's catalogue.

What I have said of the London market applies to the small curiosity shop anywhere. It is absolutely necessary that the buyer should know both the goods and the value, for he cannot safely trust either to the knowledge or the honesty of an unknown dealer, though of course it is possible that both may be irreproachable.

It sometimes happens that excellent pieces are found in 


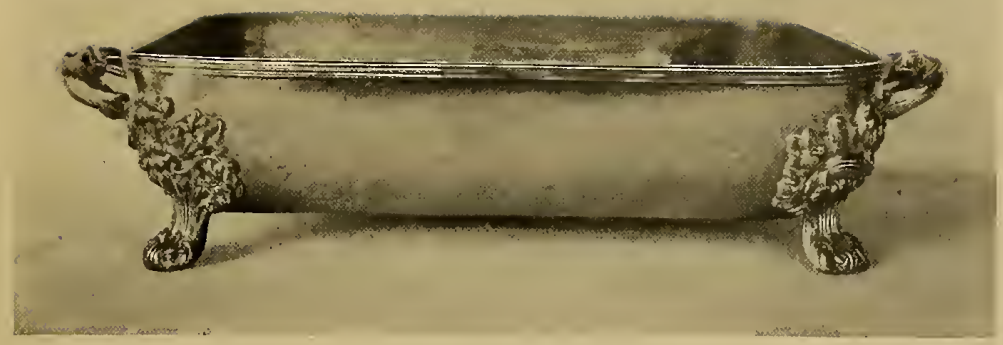

DISH WARMER (1820)

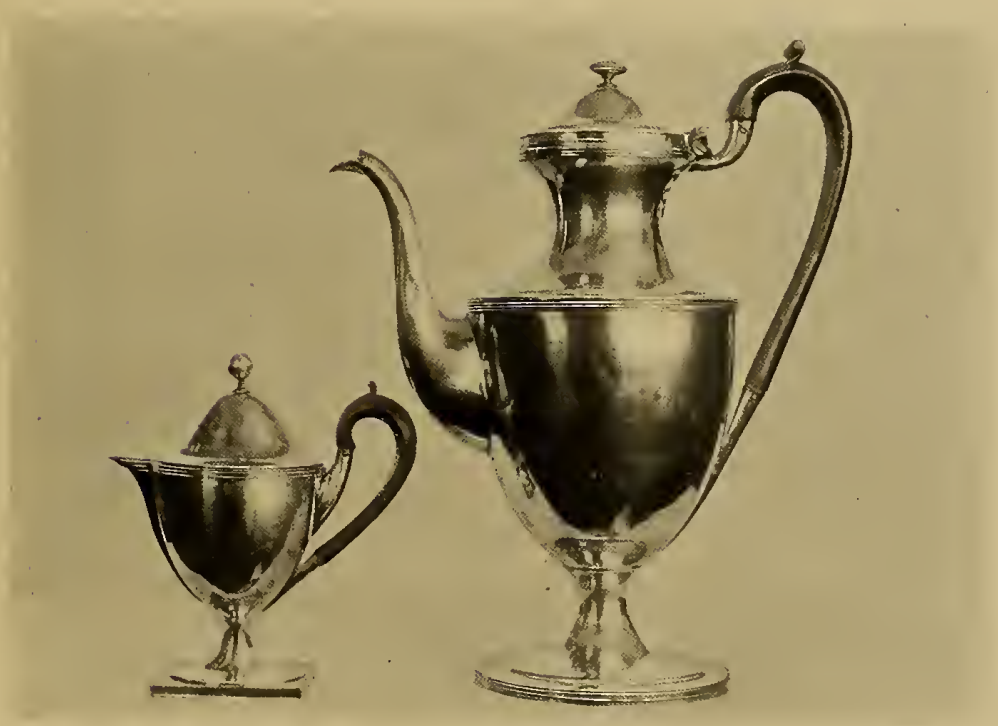

"ARGYLE" OR GRAVY-JUG, WITH HOT-WATER CONTAINER IN'THE CENTRE, AND SPOUT OPENING AT THE BOTTOM SO THAT THE GRAVY MAY BE POURED WITHOUT GREASE (I800) PLAIN OVAL COFFEE-POT (I800) 

the hands of dealers who sell very little in the way of genuine goods, for fine things do come their way sometimes and are naturally overlooked by the class of customers who usually patronize these establishments.

The dish-warmer which fits one of our entrée-dishes was purchased at a small price from a dealer who had no idea what it was, and thought that its tinned inside made it unsuitable for use. He offered as genuine plenty of fakes which he knew very well to be new productions.

At the better class pawn-shops there is an excellent chance of finding good specimens, and prices there are below the average. In this case while the seller is not without knowledge, he usually gives no guarantee and the customer must take full responsibility.

The same is true at auction sales, where everything depends upon the purchaser's ability to judge what he sees before him. The beautiful little Argyle was catalogued at a public sale as a hot-water jug by an auctioneer who did not know its purpose. A London dealer who did know wanted it, and was responsible for the high price at which we bought it. The coffee-pot which looks as if it must be a companion piece to the Argyle was bought from a dealer who appreciated its excellence and charged accordingly.

Let me repeat that the only safe course for an inexperienced buyer is to go to a reputable dealer, getting a written guarantee that the article purchased is old Sheffield Plate in original condition. Then if the article should prove not to be genuine, the seller must take it back, and refund the price.

One may buy from the general antique dealers or the silversmiths. The latter usually have workshops for repairs, and since they handle the largest quantities of silver and plated 
goods of all kinds, they are the best experts. In a general way, while the big establishments do not sell at bargain prices, they offer the compensating advantage of a larger and better chosen stock to select from.

In England more Sheffield Plate is offered in London than in the provinces, and London prices are generally higher.

As there is less to be found in the United States, it is of course more highly valued, but relative values are the same for the same reasons. Pieces not in demand are cheap, those that are rare or most suitable for modern use are expensive. New York prices strike me as about double London ones, and this seems reasonable when one considers that the American dealer must have a buyer abroad and must pay heavily for packing and transportation plus duty on articles not a century old. Nevertheless I have seen good pieces of Sheffield Plate offered in the United States for prices no higher than those asked for similar goods in England. What is less inspiriting, one sees pieces that are hopelessly worn-out and of no value except as objects for study offered at most extravagant prices.

The four candlesticks shown in the next illustration are not sufficiently dilapidated to be unsightly, but they are not in a condition to be highly valued commercially. They are of interest on account of their design. The two round ones were purchased for a few shillings, which represents their real value, for the silver is entirely worn off except on the bottom, and whatever may have been their original status, they are now nothing more or less than copper candlesticks. They owe their place in the collection to the fact that they bear the mark of a French maker and represent a typical design. 


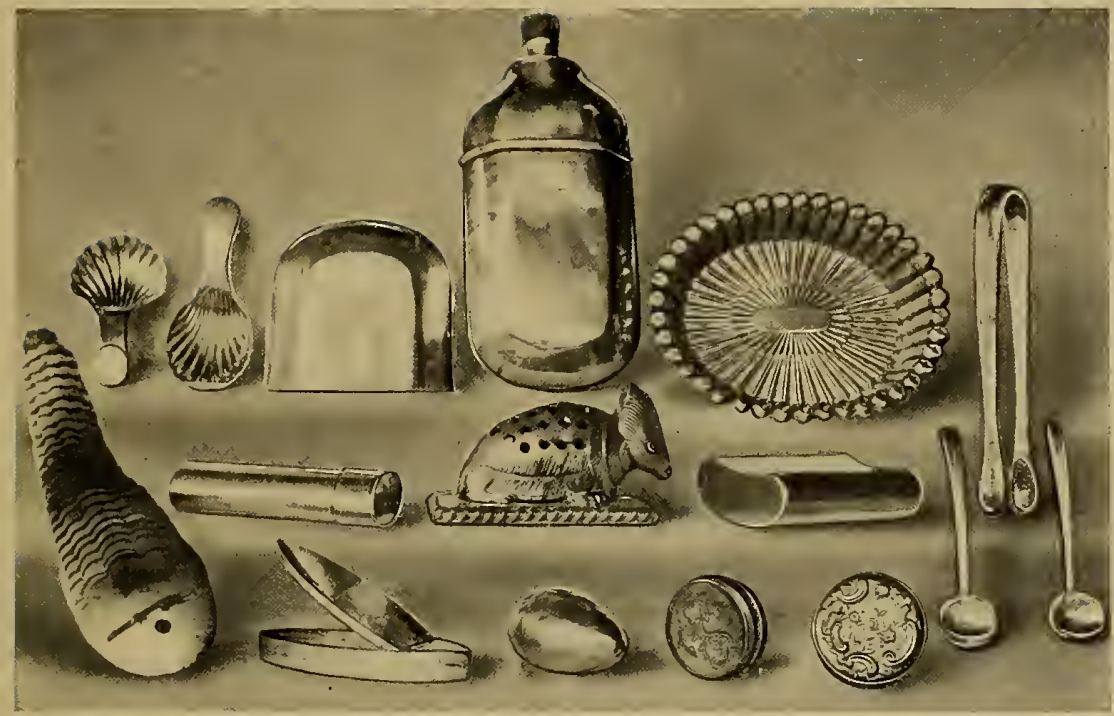

TWO CADDY-SPOONS (I770)

HUNTING-FLASK IVITH COVER (I800)

FLUTED SIVEET-DISH (I760). (See Mark, Flate XLIX)

PORTION OF EPAULET FROM NAVAL OFFICER'S UNIFORM (I800)

CYLINDRICAL BOX WITH COVER (I800)

TOOTH-PICK HOLDER OF FOREIGN MAKE (I8zo)

SNUFF-BOX (I790)

OVAL CHASED SNUFF-BOX (I780)

ROUND CHASED SNUFF-BOX WITH EMBOSSED COVER (I760)

PAIR OF SALT-SPOONS (I770)

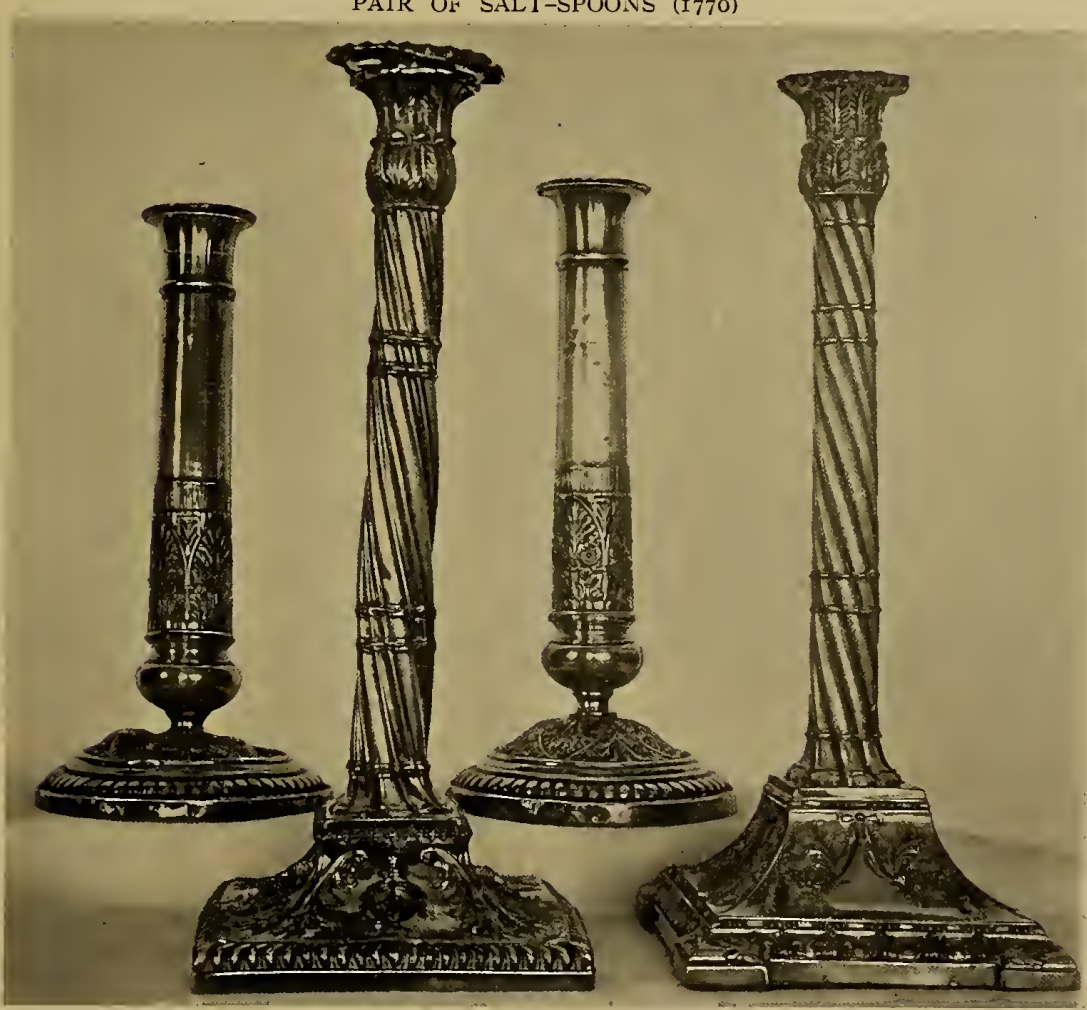

PAIR OF FRENCH CANDLESTICKS (18.30). (See Mark. Plate LII)

TWO TIVISTED COLUMN FLUTED CANDLESTICKS (I773) 



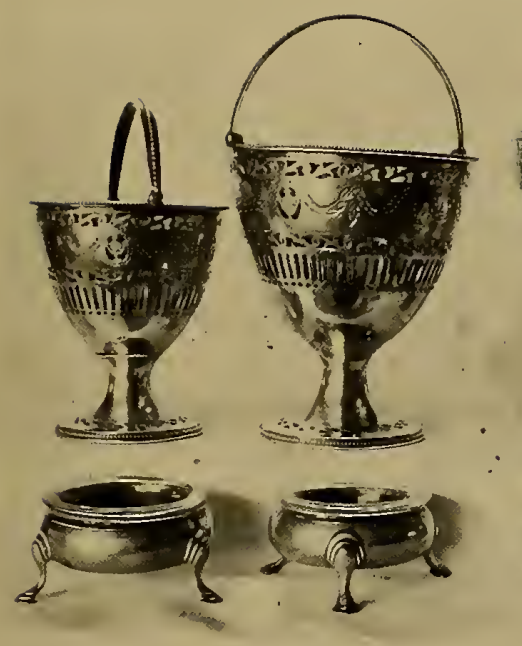

PAIR OF SILVER HALL-MARKED SUGAR AND CREAM PAILS (I780) DITTO SALT-CELLARS (I770)

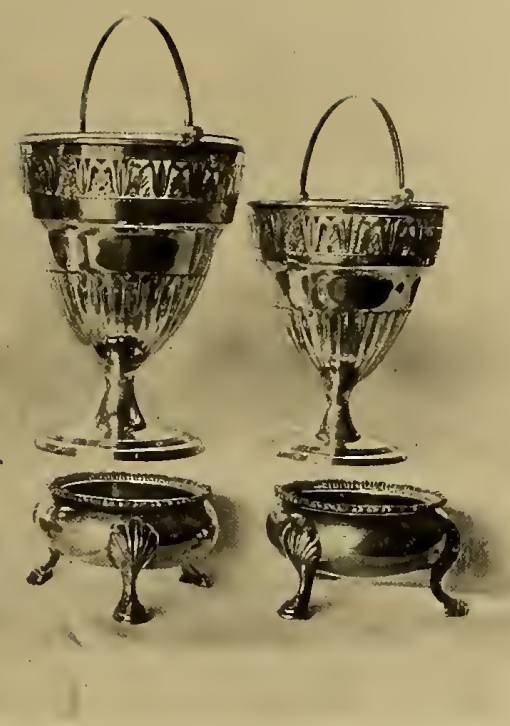

PAIR OF SHEFFIELD PLATE SUGAR AND CREAM PAILS (I785) DITTO SALT-CELLARS

(See Mark, Plate XLIX)

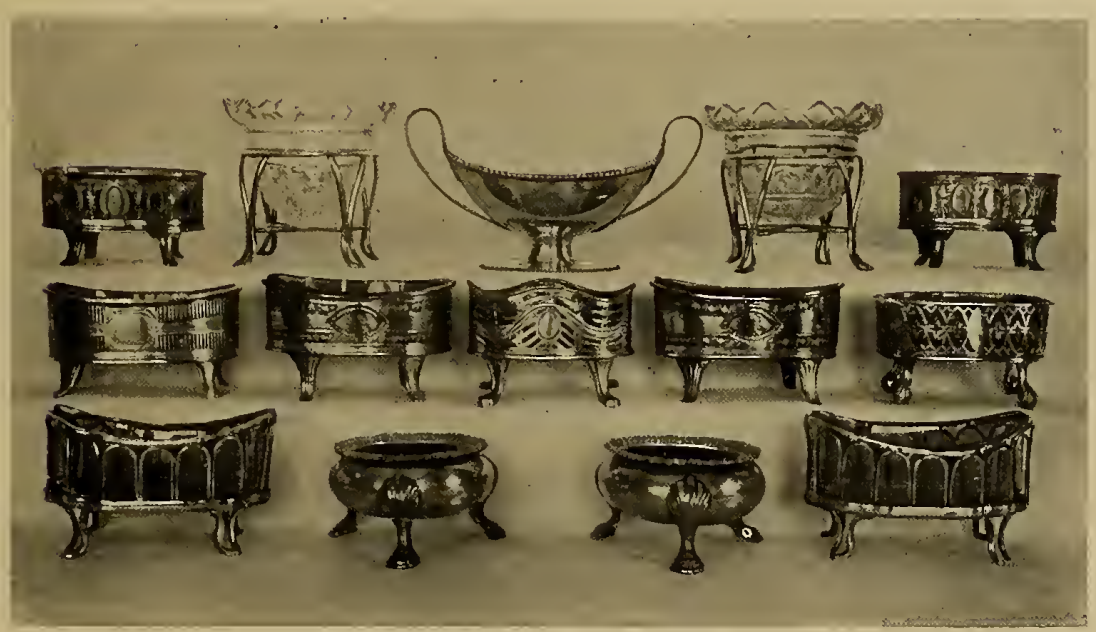

GROUP OF SALT-CELLARS ( 1765 -I804) 

As an extreme instance of the extraordinary ideas that have gained currency regarding the value of Sheffield Plate, the following incident was related to me by a well-known antique dealer. An Irish peasant woman brought into the shop an old waiter which she firmly believed to be worth

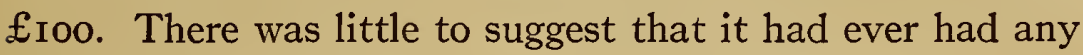
silver about it. The body was worn down to the copper and the ornate border was almost reduced to the lead filling. At best the tray had been a moderately good one of a very ordinary pattern, and in its present condition was worth no more than the price of the metal it contained. Some foolish tourists had seen the thing in the old woman's cottage, and proud of their power to recognize old Sheffield Plate, had taken upon themselves the office of valuers. As a consequence the poor old dame had travelled many miles to turn her supposed treasure into gold. She returned home sadder but not much wiser, cursing the greed of the dealer who she thought had refused from pure avarice to give her a large sum for her tray.

It should be unnecessary to state that there are other factors than genuineness which help to determine values both intrinsic and sentimental (the latter are equally real).

If one wishes articles of tableware for general utility, it is obviously foolish to pay any price whatever for pieces that are hopelessly out of condition; while there are some specimens so rare and so interesting to the collector that he is glad to have them in almost any state, and he will not allow them to suffer from further ill-use or neglect.

There is a stock remark frequently made by people with a little knowledge, that Sheffield Plate is more valuable than silver. While it is true that good old plate is worth more 
than some modern silver, because it is better designed, better made, more durable, and more pleasing generally, it never was true that Sheffield Plate, as such, was more valuable than silver of its own period. On the contrary, I hope I have made it clear that the sole reason for its existence was the fact that it was much cheaper than silver. Modern electroplated ware is made to-day for the same reason and no other. However, if the time-honored statement that "the old is better" ever applied to anything, it applies emphatically to antique silver and plated ware. While the value of each has greatly increased with a revived appreciation of its merits, and will probably increase further as the supply decreases, for pieces of the same degree of excellence the silver remains, as formerly, several times as expensive as the plated ware.

I have repeated in the preceding illustration a pair of baskets and salt-cellars for comparison with silver ones of similar design and quality. The sugar and cream baskets are perhaps equally rare in silver and in Sheffield Plate. The cost was as three ta one, while the silver salt-cellars cost a little less than twice the price of the plated ones, for the probable reason that silver ones of this pattern are rather more frequently met with.

The name Sheffield Plate has been so successfully juggled with that it now conveys little meaning to the average person. Real value is either in the articles themselves or it is wanting.

In considering the value of an article, after genuineness and condition comes the important matter of style, and here the most highly prized are not the heavily ornamented articles belonging to the later period of manufacture, though 


\section{Plate LXIV}

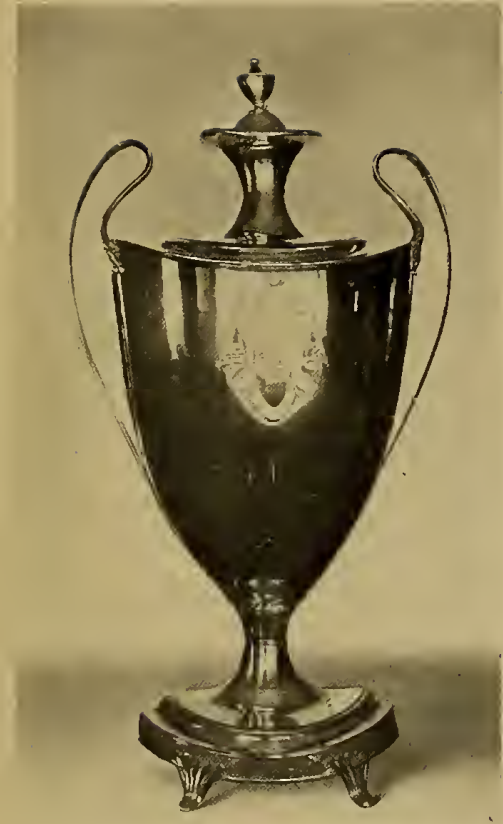

OVAL TEA-URN WITH SOLDERED-ON SILVER SHIELD AND IMITATION HALL-MARKS

(I795)

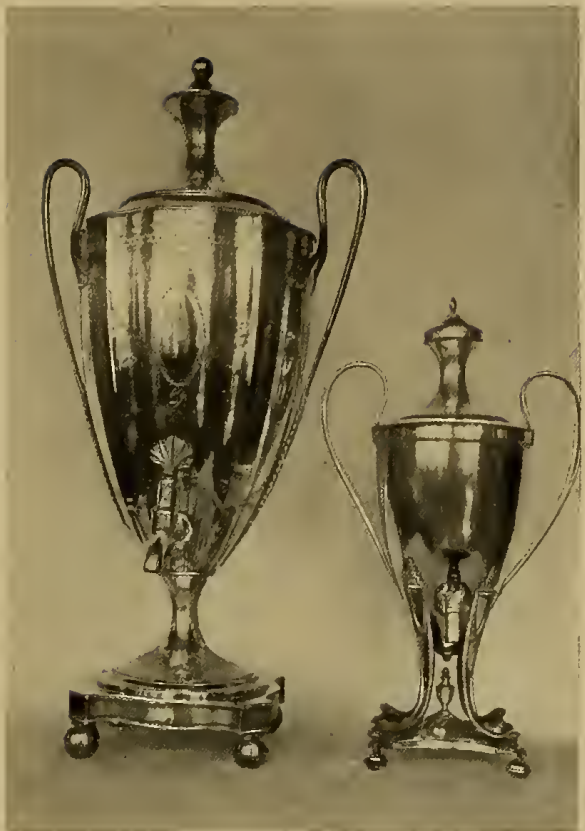

FLUTED AND CHASED TEA-URN WITH BEAD MOUNTS (I785)

SMALL TEA-URN WITH BEAD MOUNTS

(I790)

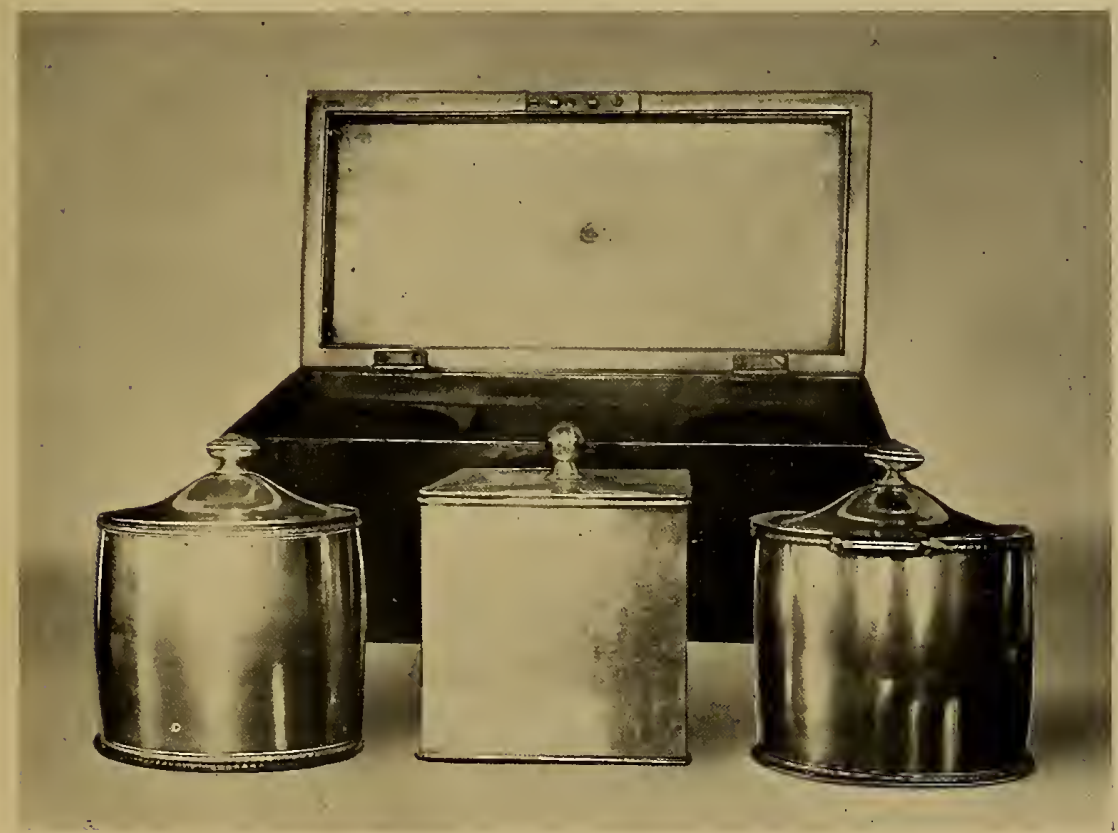

SET OF TEA-CADDIES AND SUGAR-BOX WITH ORIGINAL MAHOGANY CASE (I790) 

some of these, such as entrée-dishes or tea-trays, are very popular on account of their usefulness (and perhaps showiness). The things that appeal to a connoisseur are the delicate bits of wire-work or pierced and chased pieces, the fine. lines of the classic period, or the quaint shapes of the earlier pieces known as "Queen Anne."

As a rule the eighteenth-century pieces are more valuable than the later ones, not because they are older, but because in spite of greater age and therefore less perfect condition, they are more beautiful and more interesting, notwithstanding the very perfect workmanship which often characterizes the late pieces.

Another element that helps to determine the salability, and therefore the commercial value of an article is its adaptability to modern requirements; hence such pieces as souptureens, tea-urns, and cruets, having become obsolete (and not convertible into rose-bowls) are of ten much cheaper than their general merit would warrant, while the reverse is true of such articles as teapots, waiters, or sauce-boats. The group of salt-cellars represents a kind of article that is always expensive for its size. Practically all of the best styles are represented, and these dainty bits are so useful and so attractive to look at that they are naturally in great demand. On the other hand, while tea-urns of mediocre design can be bought for very little, such specimens as the two shown in the preceding illustration are an exception to the rule and are valuable simply because of their intrinsic beauty.

In the long run I think all collectors will agree that with few exceptions the articles from which they have derived the greatest satisfaction have been those which have cost the most, both in money and in time, and the second is more 
important. While good things are generally expensive, expensiveness does not make them good, and of course the collector who chose his specimens merely for their high price would find himself with an ill-sorted assemblage, no matter how great its commercial value.

One of the deplorable and demoralizing results of modern prosperity is the tendency to put quantity before quality, and this tendency in furnishing and decoration is by no means confined to the laborer's cottage. The quality of goods, either genuine or in the form of reproductions, offered to the average buyer of Sheffield Plate is not flattering to his taste, but his heedless ignorance is responsible. If people who care sufficiently for the old plated ware to wish to possess more of it will take the trouble before buying to learn what they want and why they want it, I am sure they will feel many times rewarded for their trouble. No one can fail to admire many of the pieces in such collections as those on public exhibition in the Metropolitan Museum in New York, the Boston Art Museum, or the South Kensington Museum in London, and a great deal may be learned from simply looking at them, while a careful study of any good literature on the subject should prevent gross mistakes in buying.

A few typical pieces which appeal to the taste of any individual cannot fail to be a lasting joy, and I can think of no investment which is bound to yield better dividends in the form of ever-increasing pleasure than an intelligently selected collection of Old Sheffield Plate. 
Plate LXV

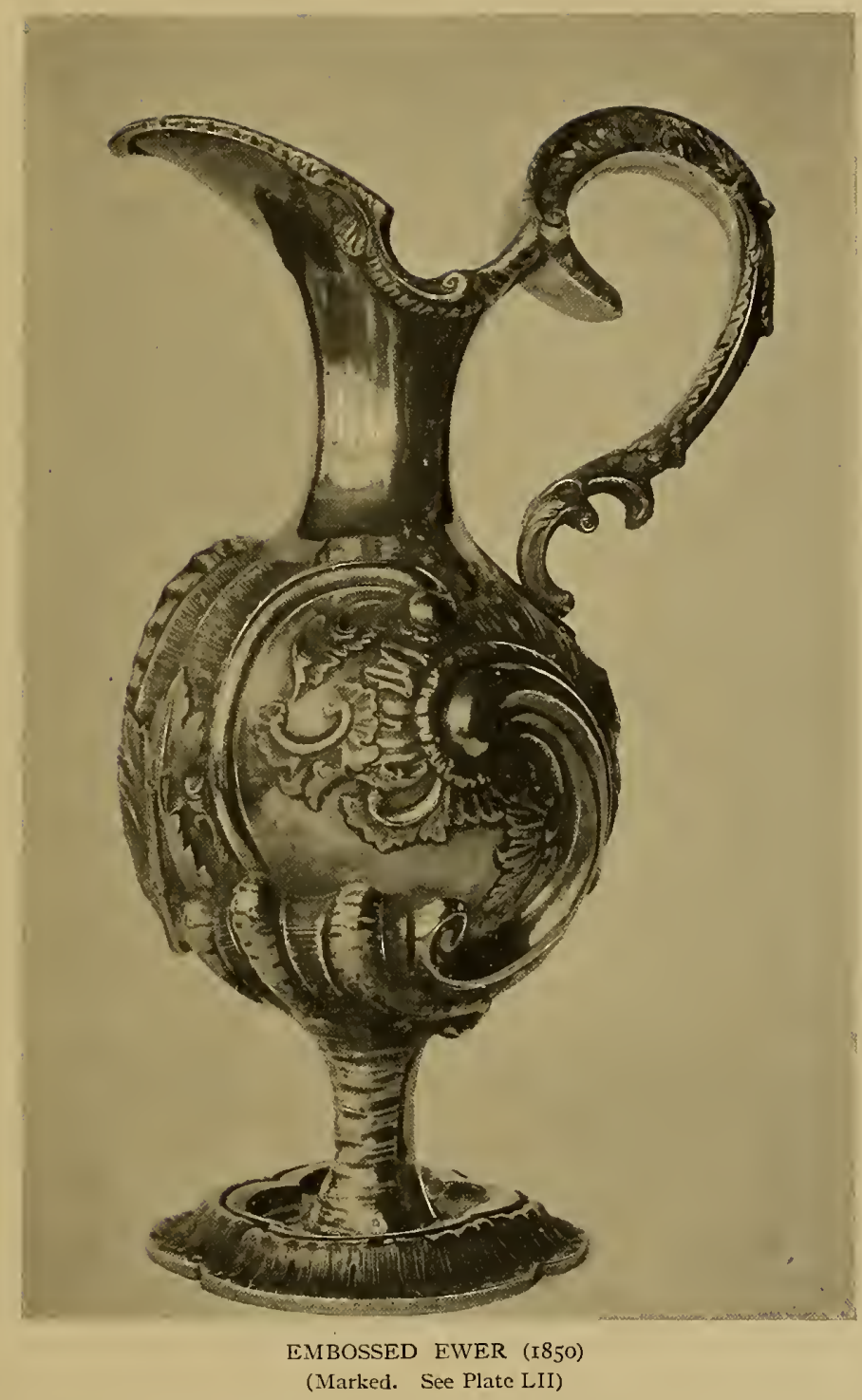





\section{XVII}

AN OBJECT FOR STUDY

TF I were asked to point out the most interesting specimen in our collection, I should immediately think of the very piece whose right to be there at all has been seriously challenged, the beautifully hand-wrought ewer which has caused us so much perplexity. It is one of those exceptional pieces that puzzle even the most experienced observers.

The ewer was one of our earliest purchases, and we accepted it without question for an unusually fine specimen of Old Sheffield Plate. After awhile, however, we were somewhat disconcerted by the discovery that it had been electroplated, although so long ago that it had acquired the surface of old silver. There were traces of solder that had run over the chasing, as if the piece had been cracked and repaired, and our first conclusion was that the plating had been done to cover the marks of repairing. As we learned more about the old process, however, we began to study more carefully the manner in which the piece had been put together. The main body of the jug is raised in two pieces, the neck also in two pieces, being cleverly joined just above the chasing. The foot is raised separately and all done by hand. The beautifully chased handle is hollow and the seams plainly visible. Now it seemed impossible that this elaborately wrought jug could have been raised from a flat sheet of rolled plate without over-stretching the surface, and we were inclined to agree with the opinion of an experienced 
silversmith that it was a copper ewer probably made in Italy a couple of centuries ago, and electro-plated much later. However, no one could explain why a copper article should have been made from thin plate with hollow handle and the edge of the lip rolled over, instead of being hammered from solid metal. Furthermore, the style of the chasing with the high relief scrolls is not Italian, but very like much of the elaborate work done on silverware in the early Victorian period. The piece also bears a small mark which, though unidentified, has been found on numerous pieces of Sheffield Plate.

Finally, with the aid of a file, we discovered that while the silver coating is very heavy on the outside, and halfway down the neck, the inside of the jug and the inside of the hollow foot are thinly plated. The square section metal wire which strengthens the edge of the foot is of brass, heavily plated on all four sides, evidently by the old method. These facts dispose of the theory that the ewer was made originally in copper, and the only one that seems to tally with all the evidence is that it represents an attempt on the part of an ambitious workman to produce in the old plate something that proved to be a little more than possible; that the metal finally refused to bear the strain in the high relief work and that the copper became exposed or perhaps even cracked. As the design is a very late one, it is probable that the piece was made after the invention of electro-plating, and I can imagine that the artist in his disappointment merely had it plated over without taking the trouble to make good the obliterated chasing. We therefore consider that this piece is fully entitled to the place of honor which it still occupies, without apology, in our collection. 


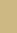


FIVE HUNDRED AND FIFTY COPIES OF THIS BOOK OF WHICH FIVE HUNDRED ARE FOR SALE WERE PRINTED AT THE RIVERSIDE PRESS CAMBRIDGE, U.S.A. 





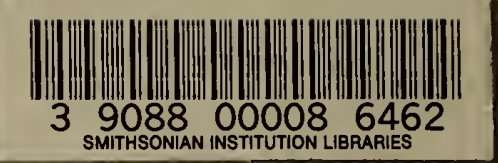

